\title{
VANDALIA: IDENTITY, POLICY, AND NATION-BUILDING IN LATE-ANTIQUE NORTH AFRICA
}

\section{BY}

\section{EUGENE JOHAN JANSSEN PARKER}

A thesis submitted to the Victoria University of Wellington in fulfillment of the requirements for the degree of Master of Arts

Victoria University of Wellington

2018 


\begin{abstract}
In 534, after the conquest of the Vandal kingdom, Procopius tells us that the emperor Justinian deported all remaining Vandals to serve on the Persian frontier. But a hundred years of Vandal rule bred cultural ambiguities in Africa, and the changes in identity that occurred during the Vandal century persisted long after the Vandals had been shipped off to the East: Byzantine and Arabic writers alike shared the conviction that the Africans had, by the sixth and seventh centuries, become something other than Roman. This thesis surveys the available evidence for cultural transformation and merger of identities between the two principal peoples of Vandal Africa, the Vandals and the Romano-Africans, to determine the origins of those changes in identity, and how the people of Africa came to be different enough from Romans for ancient writers to pass such comment. It examines the visible conversation around ethnicity in late-antique Africa to determine what the defining social signifiers of Vandal and Romano-African identity were during the Vandal century, and how they changed over time. Likewise, it explores the evidence for deliberate attempts by the Vandal state to foster national unity and identity among their subjects, and in particular the role that religion and the African Arian Church played in furthering these strategies for national unity.

Finally, it traces into the Byzantine period the after-effects of changes that occurred in Africa during the Vandal period, discussing how shifts in what it meant to be Roman or Vandal in Africa under Vandal rule shaped the province's history and character after its incorporation into the Eastern Empire.
\end{abstract}


To Mark, for his guidance and his patience.

(Cover image: A Vandal-era coin from the mint of Carthage. Obverse displays the legend "KART...HAGO," split by a standing soldier. Reverse displays a horse's head and a value mark of 21 nummi.) 


\section{Table of Contents}

$\begin{array}{ll}\text { Acknowledgements } & \text { p.i }\end{array}$

Terminology and Abbreviations p.iii

Introduction $\quad$ p.1

$\begin{array}{ll}\text { Chapter One: Romans in barbarian clothing } & \text { p.12 }\end{array}$

Chapter Two: Arriani quos nunc videmus multos seducunt $\quad$ p.28

Chapter Three: Carthago excellens Libycas per oras p.44

$\begin{array}{ll}\text { Conclusion } & \text { p.55 }\end{array}$

Appendix One: timeline of the Vandal Kingdom p.63

$\begin{array}{ll}\text { Appendix Two: images } & \text { p.64 }\end{array}$

$\begin{array}{ll}\text { Bibliography } & \text { p.67 }\end{array}$ 


\section{Terminology and Abbreviations}

\section{Terminology:}

The term "Vandal" shows up with a number of different spellings in Latin, and different renditions of that Latin, in scholarly literature: "Vandal[us, orum, etc.]," but also "Wandal...," "Vvandal...," "Uuandal...," even "Guandal... ." As these are different ways of spelling the same thing, wherever I quote from Latin, I have used a standardised form "Vandal..." for simplicity's sake.

Rather than "Catholic," which scholars often use to refer to Homoousians in contrast with Arians in late antiquity, I have elected to use the term "Nicene." This is partly because it is a more accurate term for contrasting them with Arians, but mainly because, as we shall see, the Vandal Arian Church believed itself no less catholic than the Nicenes, and the Vandal kings acted as if they were protectors of a worldwide Arian community, not merely a local religious sect. There was substance to these claims, and I have therefore chosen to treat them with respect, rather than linguistically accepting the Nicene perspective.

Pohl and Heydemann published two books in 2013, Post-Roman Transitions and Strategies of Identification, intended to be read together. As both books were published in the same year by the same authors, I refer to these in abbreviated form in the footnotes, to avoid confusion.

\section{Abbreviations:}

- $\quad A L R=$ Anthologia Latina, edited by A. Riese.

- De.Gub.Dei. = De Gubernationis Dei, Salvian.

- Hist.Per. $=$ Historia Persecutionis [Africae Provinciae], Victor Vitensis.

- O.C.D. $=$ Oxford Classical Dictionary (2012), Hornblower, Spawforth, Eidinow.

- P.R.T. = Post-Roman Transitions (2013), Pohl \& Heydemann.

- $\quad$ S.o.I. = Strategies of Identification (2013), Pohl \& Heydemann. 


\section{Introduction}

Our understanding of the late-antique Western Mediterranean has been the subject of considerable debate by recent generations of classical scholars, emerging out of a post-Second World War revision of the academic understanding of ethnicity and identity. ${ }^{1}$ Ideas about major cultural tension and hostility between the post-Roman ruling elites (generally entitled "Germanic," although even the validity of that label for all the various rulers in the West has come under fire) ${ }^{2}$ and their Roman subject masses are no longer in vogue. ${ }^{3}$ Recent discussion has focussed on the many and varied commonalities between these supposedly "barbarian" elites and their subjects, and the ways in which their interactions could be characterised, not by strife and disruption, but by cultural continuity, co-existence, and accommodation, leading to eventual merging of identities: a loss of distinction, in a strictly cultural and identitarian sense, between rulers and ruled.

We know that this fusion occurred among the peoples that survived the end of antiquity. One need only look at France and Lombardy on modern maps, as opposed to "Gaul" or "Transpadana," to see successful examples. Much recent scholarship, including Amory's People and Identity in Ostrogothic Italy (1997), Pohl and Heydemann's Post-Roman Transitions (2013), and Wolfram's The Roman Empire and Its Germanic Peoples (2005), has performed similar re-evaluation of those post-Roman elites that did not survive, arguing for a constructive and collaborative relationship between them and their subjects that gestured towards the same merger that occurred among the surviving peoples. In particular, the Ostrogoths of Italy have received a great deal of this rehabilitative treatment. The degree to which scholarship has re-evaluated ethnic relations and assimilation between them and their Italo-Roman subjects is such that one can now speak of the first Italo-Gothic king, Theodoric, as emperor-in-all-but-name, ${ }^{4}$ and the war between the kingdom and the Eastern Empire not as one between Romans and Goths, but between Romans and Italians: large swathes of the local population rallied to the Gothic banner during the Byzantine invasion, and would continue to do so until the last flames of resistance were snuffed out. ${ }^{5}$ Theodoric engaged so constructively with Roman culture that even contemporaries called him augustus ${ }^{6}$ and his state a respublica without blushing, ${ }^{7}$ and his Italians waged resistance for many years against "fellow" Romans in the name of a supposedly-barbarian regime. This suggests more affiliation and merging of identity than previous evaluations of the kingdom, with their talk of "ruling races" and strict separation between the peoples, ${ }^{8}$ ever countenanced. Similar re-evaluation has been done for the Visigoths of Spain: Wood's "Religiones and gentes in Isidore of Seville's Chronica maiora," for instance, explores the deliberate construction of a Spanish Visigothic identity that embraced local Romans while, equally importantly, excluding Eastern Romans. ${ }^{9}$

However, the Vandal Kingdom of North Africa has been a latecomer to this reconstruction. The Vandals have been subject to relative scholarly neglect until recently, for several reasons. Classical

O'Donnell (2009), p.41.

e.g. in Amory (1997) passim but especially pp.54-55, 61-62; Geary (2002) again passim but especially p.72.

Although they still have their defenders, e.g. Bryan Ward-Perkins' The Fall of Rome and the End of Civilisation (2005).

O'Donnell (2009), p.144.

Amory (1997), p.180.

O'Donnell (2009), p.144.

e.g. Cassiodorus in his letter from Theodoric to Anastasius, Variae I.1.

Ward-Perkins (2005), p.65

P.R.T., pp.125-168 passim. 
scholarship during the early modern period, influenced by the national-chauvinistic obsessions of the time, mostly paid attention to post-Roman elites whose legacies and images could be exploited for nationalistic purposes. ${ }^{10}$ The Vandals, however, left no lasting national identity in their nowArabicised and Islamicised Tunisian homeland, and their legacy was claimed mostly by regional groups of Germans. ${ }^{11}$ Thus, where much effort was put into researching and exploiting the images of Franks, Goths, etc. by various European powers, only a small amount of German scholarship went into examination of the Vandals, and then only as a Germanic people, with little interest in their relations with Romano-Africans. ${ }^{12}$ Meanwhile, the French colonial administration in Tunisia primarily displayed archaeological interest in imperial-era Roman remains, with Vandal and Byzantine remains suffering comparative neglect. ${ }^{13}$ Likewise, textual evidence from the kingdom is sparse, and the surviving sources come mostly from a hostile Nicene-Roman perspective. This has created a one-sided impression of cultural and religious antagonism that is harder to pierce than that surrounding, say, the Ostrogoths, for whom a wealth of often-sympathetic textual evidence is available. The Vandals' unsavoury reputation in modern times, although itself a product of modern cultural exploitation, ${ }^{14}$ has reinforced this picture; many scholars otherwise sympathetic to the postRoman elites (such as Amory or O'Donnell) define the Vandals by zealotry and persecution of Nicenes. ${ }^{15}$

Moves have lately been made to rehabilitate the Vandals from obscurity. Of particular importance is Andy Merrills' and Richard Miles' The Vandals (2010), the first holistic treatment of the Vandal Kingdom in over fifty years. Before this work, the previous surveys on the Vandals were Courtois' Les Vandales et L'Afrique (1955) and Diesner's Das Vandalenreich (1964), both out-of-date and coloured by their authors' ideological positions, ${ }^{16}$ and Merrills' and Miles' book thus does much to advance the field. It covers the whole sweep of Vandal history, the governance and cultural life of their African kingdom, as well as a discussion of the historiography of the Vandals. There has also been a recent profusion of articles on the Vandals, as part of larger works - including Post-Roman Transitions (mentioned above) and Vandals, Romans, and Berbers (2004), a compilation of articles on late-antique North Africa edited by Merrills - and in journals and other small publications.

The recent upswell of Vandal studies has made available intriguing evidence that suggests relations between Romano-African and Vandal in the kingdom were not as antagonistic and irreconcilable as previous generations of scholars have maintained. What has emerged from recent scholarship is a picture of two cultures "in a state of ongoing fusion which forged further ahead, and more rapidly, than that of the Franks and the Gallo-Romans," in the words of Judith W. George. ${ }^{17}$ Much evidence has emerged to support this picture, but no attempt has yet been made to put it into a single synthesis. Though the evidence is mounting for this fusion, it has thus far only been dealt with or commented on in particular instances. We lack an analysis of Vandal and Romano-African ethnic identity, relations, and integration over the Vandal Kingdom's lifetime as a whole picture.

This thesis is thus an attempt to fill that gap, by synthesising the available evidence for ethnic identity and expression, cultural relations, and the changing and breakdown of definitions and barriers between Vandals and Romans in post-Roman Africa. It seeks to bring together modern sociological thought concerning the nature of ethnic identity and the construction and maintenance

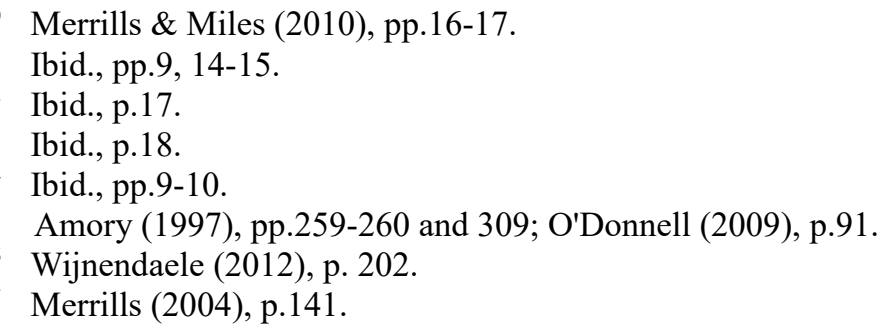


of ethnicity with the new information coming out concerning the cultural, religious, and political situation in the Vandal Kingdom. Examining evidence for relations between Vandal and RomanoAfrican in the kingdom, as well as the nature and defining traits of those ethnic identities (and how those scripts of identity changed over time), it will discuss whether they were heading towards a fusion of ethnicities, what forms that merger took, the roles played by state and religion in advancing it, and how far along it was by the time of the kingdom's fall.

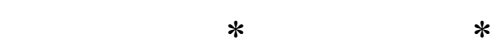

The origins of the Vandals are obscure. A group called "Astingi," whose name suggests affinity with the Hasding royal line of Vandal Africa, appears in $171 \mathrm{CE}$ on the Danube, in connection with Marcus Aurelius' Marcomannic Wars. It is generally agreed that this is the Vandals' first mention in recorded history. ${ }^{18}$ They appear occasionally after that, including a mention on the early fourthcentury Verona List of barbarians, ${ }^{19}$ but the sporadic nature of these appearances indicates that they were less concerning to Roman border commanders than larger groups like the Marcomanni or Quadi. ${ }^{20}$

The Vandals step more prominently into history as part of a coalition of groups that crossed the Rhine in 406, along with Alans and Sueves. ${ }^{21}$ This group remained in northern Gaul until 409, when the grinding civil war in the Empire allowed them to move into Aquitania and then across the Pyrenees into Spain, ${ }^{22}$ which they divided among themselves. The two groups of Vandals in the coalition, "Silings" and "Hasdings," received Baetica and half of Gallaecia respectively (a good indication of which was more powerful at the time), but the Alans, likely the strongest group in the peninsula, received the lion's share. ${ }^{23}$ This changed when Athaulf's Goths arrived in Spain. After a series of initial setbacks, including Athaulf's death, the Goths sided with Rome and crushed the Silings and Alans, whose remnants fled to join the Hasdings. Buffeted by Roman interventions, the Hasdings moved into southern Spain, where they went from a minor nuisance to a major threat. ${ }^{24}$ Castinus, the Western comes domesticorum, was sent to deal with them, but (after initial successes) he was defeated in 422 (in part due to Gothic treachery), leaving the Vandals masters of the peninsula. Winning victory after victory against Roman forces in Spain, they nevertheless seem to have concluded that their position there was untenable. Thus, the Vandals under Geiseric (possibly invited by Boniface, Roman commander in Africa, to support his position in the interminable Western faction-fighting $)^{25}$ crossed into North Africa en masse. ${ }^{26}$

In Africa, they met with little resistance. After crushing an Eastern army sent to expel them, they were granted Mauretania and Numidia as a federate kingdom in 435, but in 439 Geiseric took advantage of chaos in the Empire to seize Carthage. He agreed a treaty with Valentinian III in 442 recognising the Vandals as owners of Numidia, Byzacena, Proconsularis and parts of Tripolitania in exchange for the return of Mauretania, ${ }^{27}$ but the Empire lacked any capability to stop Geiseric

18 Merrills \& Miles (2010), p.27.

19 Shanza \& Mathisen (2011), pp.22-23.

20 Merrills \& Miles (2010), p.29. Merrills alleges the Vandals do not appear on the Verona List, which is false, but certainly the Vandals did not make too much trouble for the Roman authorities until 406.

21 Halsall (2007), p.211.

22 Merrills \& Miles (2010), pp.37-40.

Ibid., pp.43-44.

Ibid., pp.44-46.

Procopius, Wars 3.3.18-28.

Halsall (2007), pp.235-236, 239-241.

Ibid., pp. 242, 245-248. This ownership also appears to have recognised the Vandals not merely as federates but as an independent kingdom, a ghastly novelty for the Romans to deal with (Merrills \& Miles (2010), p.63.). 
from seizing Mauretania back, which he did in 455 upon Valentinian's death. ${ }^{28}$ Thus the Vandals completed the construction of their African kingdom, which was to last until 534.

The Africa they found themselves masters of had seen better days. Certain accounts of their arrival talk of cities sacked and monuments destroyed, ${ }^{29}$ and some modern scholars have attributed the shrinking and fortifying of towns in this period to Vandal invasion and rule. ${ }^{30}$ However, this shrinkage was happening across the Empire, ${ }^{31}$ and the monuments "destroyed" may simply have been taken apart and used for something else or overrun by housing and light industry, common for large public spaces in late antiquity, and a process that started in Africa before the Vandals arrived. ${ }^{32}$ While its capital, Carthage, was still a major centre of culture (second city of the West, in fact), classical urban life elsewhere was starting to slump: venerable towns across Africa diminished in size or were even abandoned altogether, ${ }^{33}$ and the economy was in decline (though not as much as in other western provinces). ${ }^{34}$ Simultaneously, Berber chiefdoms in the pre-Saharan zone that formed Africa's borderland were growing in strength and organisation in the fifth century. ${ }^{35}$ Their uprisings were already shaking Roman Africa and the wider empire in the $390 \mathrm{~s},{ }^{36}$ and the chiefdoms that formed in this time would plague the Vandal Kingdom with border conflicts and raids from its inception to its demise, and in turn harry the Byzantine administration that followed. ${ }^{37}$

The province was also rife with sectarianism - not uncommon in this period, but the religious conflicts in Africa had a peculiarly violent and gangsterish character unusual elsewhere. The ordination of a bishop for Carthage in 311, Caecilian, had provoked widespread outrage: Felix of Aptungi (who had ordained Caecilian) and the previous bishop Mensurius (Caecilian's mentor) were both accused traditores, people who had handed over the scriptures in Diocletian's Great Persecution. Thus, Caecilian's ordination was unacceptable to many Africans, who were among the hardest hit by the persecution. ${ }^{38}$ These oppositionists appointed their own bishop, Maiorinus, followed by one Donatus after the former's death; thus, the groups became known as the Caecilianists and the Donatists. Pope Miltiades and Constantine ruled in favour of Caecilian, ${ }^{39}$ but the Donatists refused to concede, and so began another period of official persecution in Africa that was still ongoing when the Vandals arrived..$^{40}$ This background of religious division and violence is important to bear in mind for understanding the peculiar religious landscape of Vandal Africa.

In many ways, Africa was a staunchly traditional province. The tria nomina, the classical Roman naming system largely vanished elsewhere in the Empire, is still attested in sixth-century Africa, ${ }^{41}$ and many old-fashioned civic institutions and priesthoods, such as the flamines perpetuui, lingered on well into the Vandal period, albeit stripped of their traditional religious functions: the epitaphs of

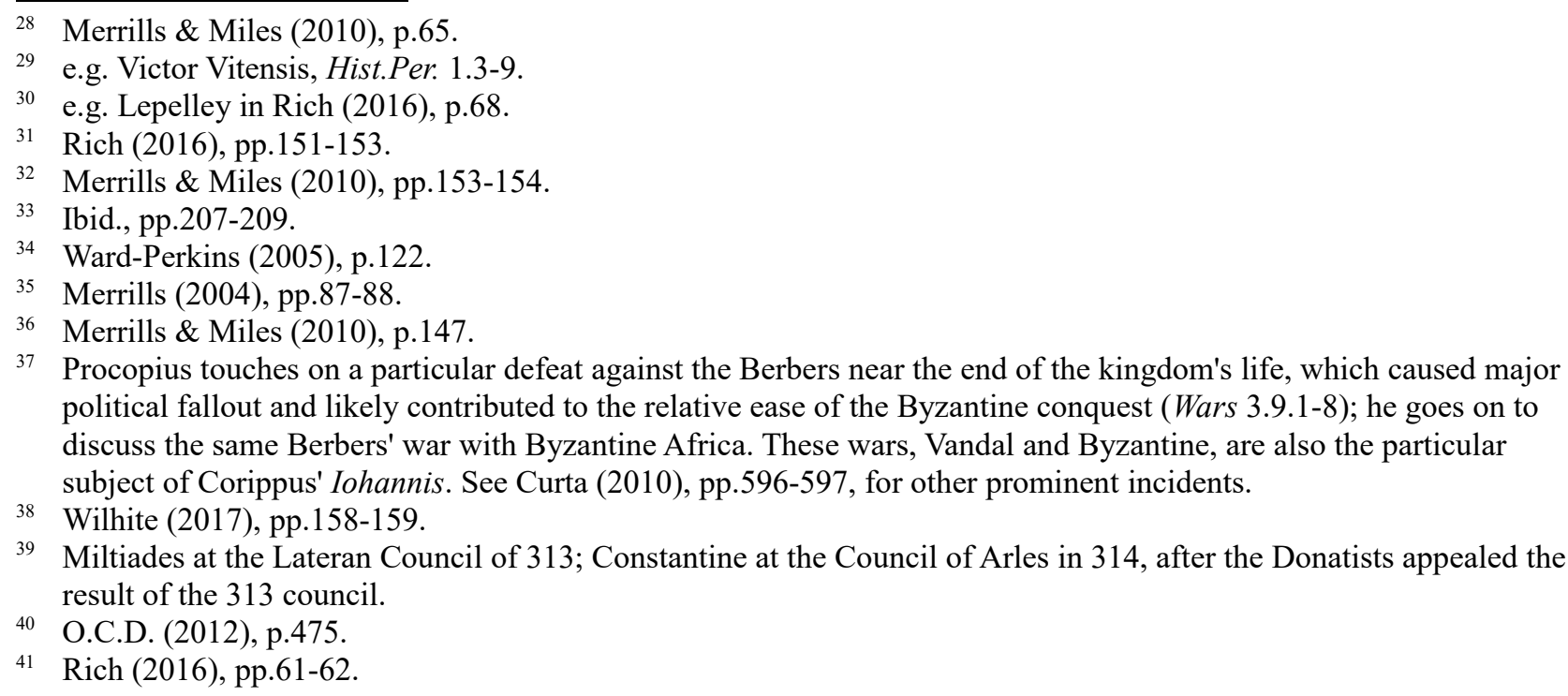

39 Miltiades at the Lateran Council of 313; Constantine at the Council of Arles in 314, after the Donatists appealed the result of the 313 council.

40 O.C.D. (2012), p.475.

${ }^{41}$ Rich (2016), pp.61-62. 
respectable sixth-century Christian senators proudly list titles such as flamen perpetuus or sacerdos. ${ }^{42}$ We shall explore the ramifications of their continued survival in the Vandal world in Chapter Three, but for now it serves to note that markers of Roman civilisation long-disappeared elsewhere still held on in late-antique Africa.

Latin literary traditions also still flourished in late-Roman Africa, and indeed continued to do so under the Vandals. Classical education remained strong, and an immense corpus of poetry and theological writing remains from Vandal Africa, which provides an invaluable resource for historians today. ${ }^{43}$ Despite this, the Vandal Kingdom lacks something that most other post-Roman kingdoms have, with grave ramifications for modern historians: a great work of Vandal history. Most western post-Roman kingdoms produced grand, sweeping histories of themselves, usually via sympathetic Roman writers, such as Cassiodorus' Gothic history (not actually extant, but a major influence for Jordanes' Getica) $)^{44}$ or Gregory of Tours' Historia Francorum, allowing us to glimpse their history and present situation from their own perspective. The Vandal Kingdom in Africa is unique in that it never produced any similar narrative of itself, or if it did, it did not survive. ${ }^{45}$

In the absence of a sympathetic, officially-condoned narrative, historians and scholars have relied largely on sources not associated with, and often hostile towards, the Vandal government. Two texts in particular, Victor Vitensis' Historia Persecutionis Africanae Provinciae and Procopius' Wars, historically provided the main points of reference for discussing the kingdom. ${ }^{46}$ Neither source is favourable to the Vandals: together, they create a largely negative picture which has only relatively recently come under review. Invaluable as they are to understanding the kingdom itself and the scholarship surrounding it, I will describe them here.

The first, generally used as reference for the kingdom's internal conditions, is the Historia Persecutionis Africanae Provinciae, hereafter called the Historia, by Victor Vitensis. The Historia is a three-book work, written in Africa, whose chief subject is the persecution of Nicene Christians under the second Vandal king in Africa, Huneric (though it also includes a brief history of the Vandals' arrival in Africa and of the less severe persecutions by Huneric's predecessor, Geiseric). Victor, a native of the town Vita in Byzacena, was probably a priest in Carthage during the persecutions.$^{47}$ His work is an eyewitness to a tumultuous period in the kingdom's history. Various dates have been proposed for the book, ${ }^{48}$ but it is clear that Victor was present for many of the events he describes; for instance, he mentions visiting Nicene clergy imprisoned for refusing to renounce their faith. ${ }^{49}$ Due to his epithet, Victor is sometimes identified with Victor, bishop of Vita at the time of Huneric's 484 debate between Nicenes and Arians, but Moorhead dismisses this possibility: Victor-the-bishop did not attend the conference, while Victor-the-author's narrative makes it clear that he did. ${ }^{50}$ The Historia is a polemical work, likely intended (in part) for a foreign, perhaps imperial audience as a request for aid; ${ }^{51}$ as such, it is full of gory and salacious accounts of

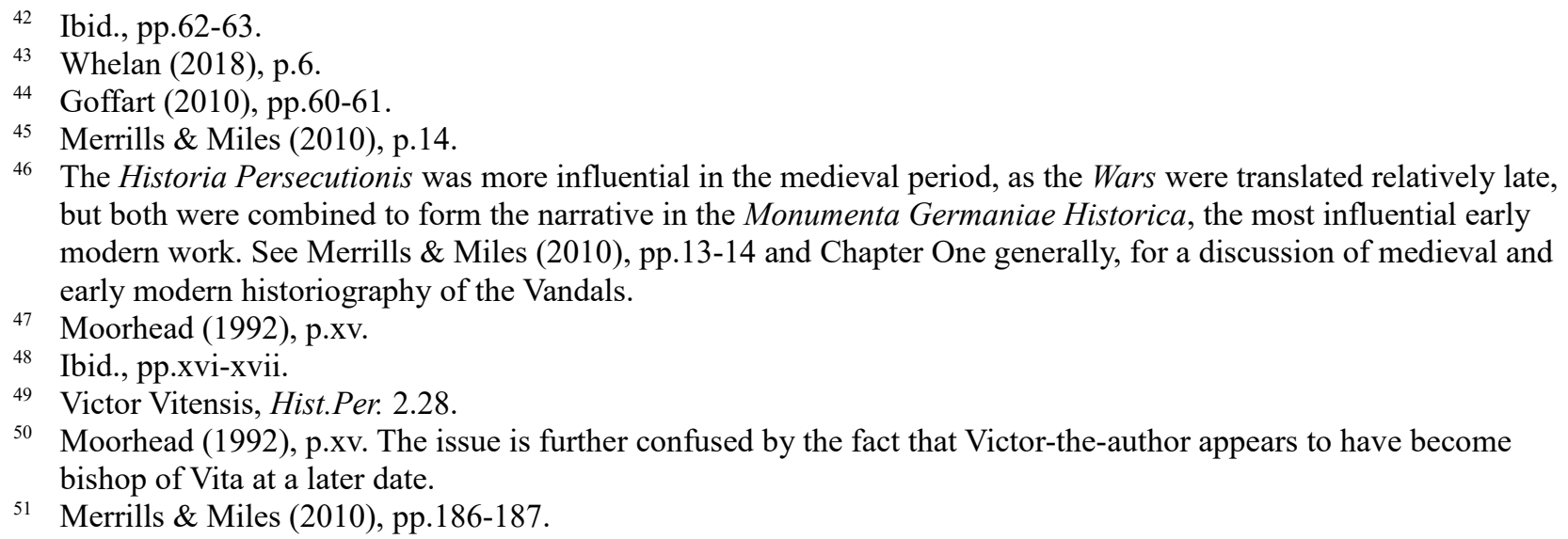


Vandal torture and harassment of Nicenes, and tries to draw a binary distinction between Vandals as Arians on the one hand and Romans as Nicenes on the other, although in places it acknowledges the existence of individuals who defy this categorisation. ${ }^{52}$ This agenda of making the Vandals look as wicked and monstrous as possible runs throughout the book, a partisanship that sometimes makes it dubious as a source (its flaws and contradictions will be discussed in greater detail throughout this essay). Nevertheless, it represents a genuine eyewitness perspective on the middle years of the Vandal period, and thus cannot be lightly dismissed.

The other major traditional source for discussing Vandal Africa is the chronicle of its demise. Procopius' De Bellis, hereafter called the Wars, narrates Byzantine exploits on various frontiers, but with the kingdom's textual record as spotty as it is, his coverage of the conquest of Africa in books 3 and 4 of the Wars (conventionally called the Vandal War or De Bello Vandalico) has assumed particular importance for discussions of late-period Vandal Africa. Procopius was legal secretary to Belisarius, the Justinianic general who conquered Africa, and was present with him on the campaign ${ }^{53}$ this puts him in the position of an eyewitness, albeit a not-terribly-sympathetic one, to the kingdom's last days and its fall. For this alone, Procopius would be invaluable, but he provides, in the opening sections of De Bello Vandalico, a sketch of Vandal history that likely draws on genuine Vandal traditions, ${ }^{54}$ and various other passages indicate that he spoke to some Vandals after the conquest. ${ }^{55}$ This makes the Wars one of only a few places where a Vandal voice comes through to us, if indirectly. Nevertheless, Procopius should not be mistaken for sympathetic: for instance, he ascribes the kingdom's swift defeat by Belisarius to decadence and luxury sapping the Vandals' warrior spirit, ${ }^{56}$ and his justification for Justinian's campaign in Africa rests, in part, on the same images of Arian persecution that Victor evokes in the Historia ${ }^{57}$

These two texts form the framework around which most subsequent narratives of the Vandal Kingdom have been built. They are the largest and most detailed surviving works of history on the kingdom; ${ }^{58}$ as mentioned above, this has led to scholars leaning heavily on them when tracing its history. Read at face value, both texts create a picture of sharp divide between Romano-Africans and Vandals, an irreconcilable cultural gulf maintained by both sides. But the books are just as interesting for their antitheses. Victor admonishes other Romano-Africans for loving and admiring the Vandals, ${ }^{59}$ which points to Romano-Africans who got along just fine with their Vandal rulers (even finding them praiseworthy: Salvian, a Gallo-Roman moralist whose work De Gubernatione Dei commends the Vandals for disdaining luxury and practising better Christian morality than the Romans, ${ }^{60}$ hints at such attitudes). Meanwhile, Procopius' mention of African peasants launching guerilla attacks on Byzantines during the invasion ${ }^{61}$ implies that many locals were less enthusiastic about rule from Constantinople than is often assumed. Critical reading of the texts produces insights into the kingdom's internal conditions that are otherwise not apparent.

Recently, to move beyond the agendas and limitations of these main sources, scholars have been examining a number of smaller, less straightforward texts to see what they can tell us about the Vandal Kingdom. These include clerical writings, surviving legal documents, and the works of a

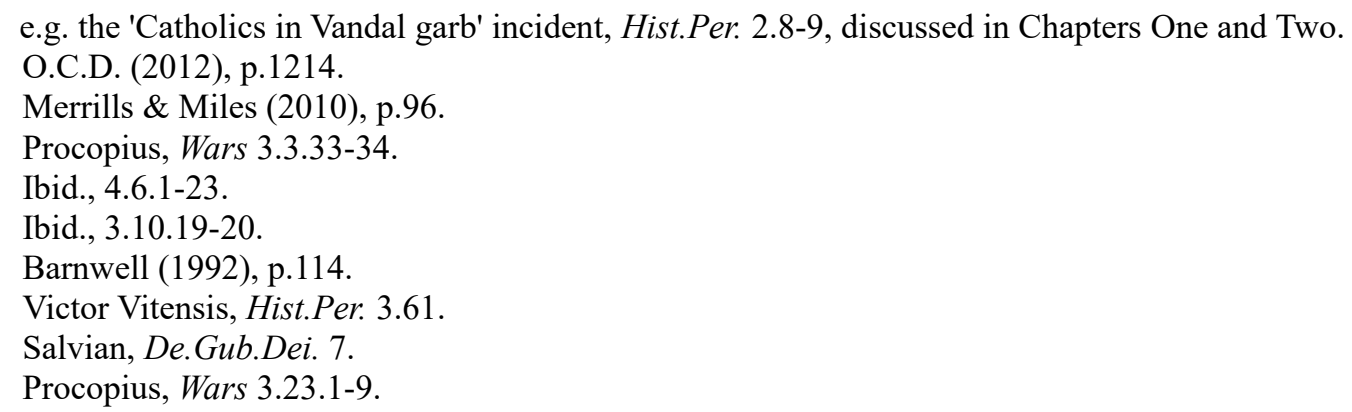


number of poets. Prominent individual poets include Dracontius, a poet with a long (often fraught) career in Vandal Africa; Luxorius, Florentinus, and Felix, court poets; and Corippus, an aristocrat from the kingdom's final years and the early years of Byzantine rule, who wrote the Iohannis, an epic to the Byzantine general John. These will be explored in their appropriate places, but a special mention should be made of the largest body of poetry from the kingdom, the Latin Anthology or Anthologia Latina. The Latin Anthology is a compilation of Latin poetry, dating from the final years of the Vandal Kingdom. ${ }^{62}$ A vast and varied body of work, containing material from both classical poets like Virgil and Ovid and Romano-African authors in the post-Roman period, the Anthology's notability stems from the fact that it is the largest surviving source of Vandal-era Latin poetry from Africa. Modern critics judge few of the Anthology's poets accomplished in literary terms, even compared to contemporary Vandal poets like Dracontius, ${ }^{63}$ but the collection provides a broad and detailed picture of the cultural and literary tastes of the kingdom's elite, and is thus an invaluable source into how the Vandal-era elite saw themselves and the world around them.

The picture it paints is not one of great strife and disruption, as is commonly attributed to the Vandal period, but of a cultivated world of talented poets, steeped in classical learning, enjoying a symbiotic relationship with their elite patrons: in short, a world in which the best artistic traditions of the Greco-Roman world thrived even in this late age. In its verses we find celebrations of skilled charioteers, admonishments of corrupt army officials, praise for rich men's cultivated gardens, and crude jokes about lawyers, a set of subjects familiar to any student of classical poetry. That Vandalera poets and their rich patrons had such similar cultural touchstones to their Imperial-era predecessors does much to dispel the images of destruction and collapse that surround the Vandals. In Africa, their patronage kept the flame of classical learning alive.

Increased use of these sources allows modern scholars to construct a broader and more nuanced perspective of Vandal Africa than that of Victor and Procopius. Relationships between Vandal and Romano-African appear less strained than most previous works usually give credit for. This is not surprising, given what we know about the other western kingdoms at this time, where the new ruling elites generally engaged thoroughly and constructively with the culture of their Roman subjects. ${ }^{64}$ More surprising, however, is the degree to which the two peoples had begun to merge by the time of the Byzantine invasion. By the end of antiquity, the surviving western ruling elites largely merged with their subjects from a cultural and ethnic perspective, but even during the sixth century, the Vandals appear far along in this process. In terms of cultural expression and religious affiliation, the hallmarks most intimately connected to ethnic identity in late antiquity, Vandals and Romano-Africans had become so alike as to be practically indistinguishable. Vandal ethnic identity had become fluid and mobile, and many Romans were adapting themselves to it in ways that left little difference between themselves and their rulers. What does this mean for relations between the two ethnicities? Were the peoples of Vandal Africa coming together in the process of forming a new ethnic identity?

To answer this question, we must consider the nature and definitions of ethnicity and ethnic identity, concepts which have always been tricky to define. Different scholars in separate fields describe the concept of ethnicity in different ways, and the markers that members of a particular group use to define themselves against other groups can change drastically over time. There have historically been two camps in the social sciences concerning ethnicity: essentialism, which regards ethnicity as a static, objective phenomenon, independent of social or political contexts and situations; and

62 Elsner \& Lobato (2017), p.181.

${ }_{63}$ Merrills \& Miles (2010), p.225.

64 e.g. Theodoric's reconstruction of the Theatre of Pompey, in Cassiodorus' Variae IV.5.1-4; or the enrollment of Vandals in classical Greco-Roman education (Merrills (2004), p.120.). 
constructivism, which regards it as fluid, performative, and dynamic, shaped by and reactive to outside forces and contexts. ${ }^{65}$

Within sociology itself, constructivism has long since won out. This change has made its way into classical scholarship over the years: even modern scholars hostile to the post-Roman ruling elites, such as Ward-Perkins, concede it is no longer scholastically viable to believe that "ethnic behaviour and identity are genetically-transmitted, and therefore immutable." ${ }^{66}$ But many conclusions remain in discussions of late antiquity that are ultimately drawn from an essentialist point of view. WardPerkins himself employs essentialist ideas of Roman ethnic signifiers when he characterises the moustache worn by the Ostrogothic king Theodoric in a coin-portrait as "a sign of his unRomanness, indeed of his Gothicness. ${ }^{" 67}$ Such a statement assumes no changes in signifiers of Romanness since Augustan times, when a moustache would indeed strike viewers as un-Roman, but when emperors as early and unquestionably Roman as Constantine sported moustaches in some depictions (fig.1), arguments that moustaches assert alien identity become difficult to sustain for Theodoric's time. Regarding Theodoric's moustache as a profoundly anti-Roman statement assumes that cultural markers of Romanness remained static throughout antiquity, a form of essentialism that still lingers in the field of classical scholarship.

Jonathan Hall, in his Ethnic Identity in Greek Antiquity, introduces several approaches to ethnicity in antiquity from an anthropological perspective. Of chief importance to the definition of ethnicity and maintenance of ethnic identity are his presentation of Donald Horowitz's definitions of "criteria" and "indicia" 68 and Anthony Smith's characteristic features of an ethnicity-as-social-group. ${ }^{69}$

Hall defines "criteria" as the definitional set of attributes by which membership in an ethnic group is ultimately determined; in other words, the key traits that define membership of an ethnicity. Criteria result from social choices that attach significance to certain attributes while discounting others. Most commonly, they involve an appeal to common descent, a shared ancestry claimed by the group in contradistinction to other ethnic groups. On the other hand, "indicia" are the operational set of distinguishing attributes associated with particular ethnic groups once criteria are established; that is to say, the surface-level ways in which members of ethnic groups proclaim their identity. Potential indicia include clothing, language, artwork and architecture, religious expression, etc.

But the Vandals are puzzling in terms of both criteria and indicia. The most usual criterion for ethnic membership, that of descent, makes little sense in their case: the Vandals absorbed multiple ethnic groups on their journey through the Empire to Africa, including certain Romans, and these appear to have assimilated into the Vandal body without difficulty. ${ }^{70}$ Likewise, individuals within the kingdom appear to have been able to adopt aspects of Vandal identity without much fuss, ${ }^{71}$ suggesting the Vandals did not place all that much weight on shared descent as an ethnic criterion. The closest thing we have to any official statement concerning Vandal descent is an anonymous

\footnotetext{
Surdu (2016), p.44.

Ward-Perkins (2005), p.77.

Ibid., p.73.

Hall (2010), pp.20-21.

Ibid., p.25.

70 These included other "barbarian" groups like the Alans, who had disappeared by 534 (see Gaggero (1996) for a survey of all attestations of Alans in Vandal Africa, concluding that the Alans had vanished by the kingdom's end), but also various Roman groups, including the remnants of Castinus' army (Merrills \& Miles (2010), pp.50, 84).

71 Halsall (2007), pp.326-327.
} 
ekphrasis in the Latin Anthology dedicated to King Hilderic, ${ }^{72}$ but this poem confuses the issue further. Where other western kings played up the virtue and sanctity of their bloodlines ${ }^{73}$ Hilderic's ekphrasis gives equal weight to both his Roman and Vandal ancestry. While his descent from the Theodosian dynasty receives some attention, the Hasding stirps is not even mentioned. What are we to make of descent as a criterion for Vandal ethnicity if even Vandal kings downplayed their Vandal blood?

The indicia lead to more puzzles. Although we lack a work of history from the kingdom's own perspective, we have a great body of poetry and artwork from Vandal Africa, enough to build a sophisticated portrait of the kingdom's cultural landscape. In all that body of work, almost nothing survives to suggest that the Vandals emphasised their difference from the Romans they ruled in any form conventionally associated with an ethnic group. The Vandalic language is barely attested, and it is now largely agreed that once-promising references to "Vandal garb" from Victor actually refer to court clothing of a standard late-antique nature. Vandal-period graves, on excavation, have brought forth nothing out of place in a Roman context. Vandals in the Latin Anthology are indistinguishable from Romans in their hobbies, pleasures, cultural tastes, or even the ways in which they liked to receive poetic praise. These examples will be considered later in this essay, but it is noteworthy that, going by the surviving evidence, ethnic differences in the Vandal state were barely outwardly expressed, if at all.

Smith's criteria raise similar issues. Anthony Smith identified six features that define an ethnic group, as distinct from any other social grouping. These are a collective name, a common myth of descent, a shared history, a distinctive shared culture, an association with a specific territory, and a sense of communal solidarity. ${ }^{74}$ The Vandals had some of these, but not all. Their culture, as discussed above, was not distinctive, identical as it was with the Romano-Africans around them. Their particular territory was Africa itself. While Procopius assigns them a homeland near the Black Sea ${ }^{75}$ when the kingdom was destroyed, no Vandals are mentioned as returning there, and when a number of Vandals pressed into Byzantine armed service mutinied and took over their transport vessel, they sailed straight back to Africa. ${ }^{76}$ They had no common myths of descent (indeed, they were well aware of their heterogeneous nature even in the kingdom's last days), ${ }^{77}$ and while they had a sense of shared history, we know little of it. ${ }^{78}$ They had a collective name (albeit one on shaky ground, due again to their mixed nature) and a sense of communal solidarity. Apart from this, they have few of Smith's defining features.

Hall acknowledges many of the problems of trying to use shared traits as a metric for ethnic identity, and suggests that a more constructive approach is to look at boundaries instead, and how the groups in question maintain and set them. ${ }^{79}$ This is in line with modern sociology, where "boundary maintenance" is accepted as the critical defining factor for ethnicity. According to Fredrik Barth, who coined the term, it is the "ethnic boundary that defines the group, not the

72 AL $R 204$.

73 e.g. the Ostrogothic Amal royal strips in Cassiodorus-Jordanes. See Wolfram (2005) pp.26-29 for a broader explication, tracing the Amals back to Gaut/Gapt, a variation on Odin/Wotan.

74 Hall (2010), p.25.

75 Procopius, Wars 3.3.1.

76 Ibid., 4.14.17-22.

77 e.g. the dual-ethnic title used by Gelimer, the last king: "rex Vandalorum et Alanorum." See Steinacher, "Who is the Barbarian? Considerations on the Vandal Royal Title," in P.R.T., for a discussion of the usage and meaning of this title even after the Alans were no longer extant in the kingdom.

78 Procopius spoke to some Vandals about their history after the conquest (Wars 3.3.33-34.), which suggests a sense of shared history. However, as it comes through the medium of an unsympathetic Roman historian, we get only small glimpses of it, and no indication as to how much these recollections were shared by the Vandals as a whole.

79 Hall (2010), pp.23-25. 
cultural stuff that it encloses." $"{ }^{80}$ These barriers are more social, economic, or environmental than strictly cultural. ${ }^{81}$ Importantly, they are defined not by members of the ethnic group themselves but in a wider societal context, ${ }^{82}$ most often by the dominant group in a given society. ${ }^{83}$ Pohl refers to these social boundaries, and their maintenance by the post-Roman ruling elites, as "strategies of distinction," aspects of identity which serve to other certain people as members of a different group. In our case, they are the methods by which post-Roman elites distinguished themselves from the Romans they ruled. ${ }^{84}$ They exist alongside "strategies of identification," or construction of common identity, aimed at enhancing and reaffirming one's status as part of an ethnic group. The two are essentially the same phenomenon considered from different perspectives, identity and alterity.

Ethnicity, then, is a dialectical subject, defined by parallel and opposing conversations between different social groups about who is and is not included and which signifiers confer membership. These signifiers, indicia, change over time, gaining, retaining, or losing their valence as circumstances change the discourse.$^{85}$ Ethnic groups keep up the meaning of their signifiers by an active (though not necessarily conscious) process of boundary maintenance, differentiation via education, skills, occupation, and other social factors. Political actors also play a role in this process of boundary maintenance, creating and reframing conversations about ethnicity to pursue their own ends. ${ }^{86}$

Even on the subject of boundaries and strategies, though, the Vandals are unusual. Vandal identity was tied to two distinct indicia: armed service (and its accompanying privileges) and belief in Arian Christianity. ${ }^{87}$ These traits, military service and Arian faith, formed the most common strategies of distinction among the western elites. But the Vandals introduce unique complications into the picture. We will explore both of those indicia in this essay, but it is important to note that Arian belief is far from a clear-cut matter. There were plenty of Arian Romans in Vandal Africa, and (thanks to Victor) one of the things the Vandals are most famous for is attempting to convert the entire population of their kingdom. ${ }^{88}$ Likewise, we know the Vandals recruited from the RomanoAfrican population, ${ }^{89}$ and these recruits received the privileges of military service enjoyed by the Vandals. $^{90}$

This thesis seeks to examine the barriers that the Vandals erected around themselves in the light of this constructivist, boundary-maintenance approach to ethnicity, to determine how well they hold true, and what the definition of a "Vandal" versus a "Roman" was by the kingdom's end. The social barriers mentioned above, religion and social role as warriors, became increasingly permeable throughout the kingdom's lifetime, until the only distinction that really remained between the Vandals and the Romans was service in the army and its privileges. To that end, I will argue that, by the time of the invasion, the Vandal and Roman populations of North Africa were well on their way to a fusion of the kind we later see with, for instance, the Gallo-Romans and the Franks.

The first chapter discusses evidence for how Vandals and Romans conceived of themselves in post-

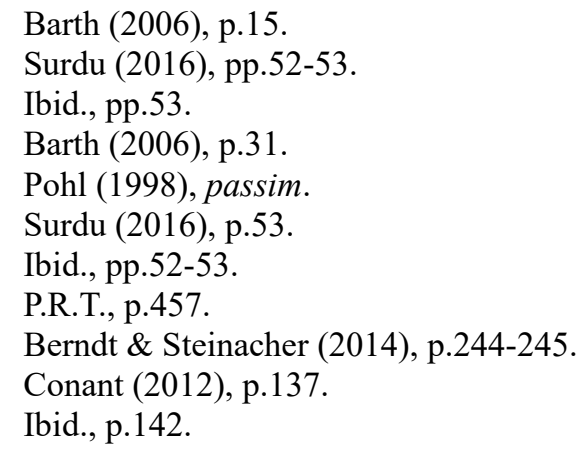


Roman Africa, and how they related to each other. It examines surviving evidence from the Vandal Kingdom from the perspective of boundary maintenance and dialectic construction of ethnicity, exploring the available dialogue about ethnicity in Vandal Africa, and who was included and excluded in that conversation. It looks at evidence for indicia and criteria used by the major groups of Vandal society to define themselves and each other, strategies of distinction the Vandals employed in Africa, and how boundaries between ethnic groups manifested themselves. Further, it looks at ways in which these markers of ethnicity changed over time, as more conventional ethnic differences became less important and social role came to play a greater part.

The second chapter discusses Arian and Nicene belief in North Africa and the wider Empire, their relationship with ethnicity in the Vandal and Roman mind, and the ways in which the Vandal state promoted Arian religion, as well as Nicene responses to this. Arianism was a key strategy of distinction for many western elites, but, far from maintaining this boundary, the Vandals pressed their beliefs on the whole African population. We have more Nicene responses to this than Arian polemics, but reading between the lines shows us that more Nicene Romans took up Arian beliefs than Nicene writers readily admit. Arianism adapted itself to conditions in Africa in interesting ways, pointing in some respects to an accommodation between Arians and local Christian traditions. Religion was an important aspect of official definitions of a loyal citizen in late antiquity, but also a key indicium for both Romans and Vandals, and this chapter will discuss the implications for identity of the Vandals' religious policies in Africa.

The final chapter discusses the ways in which the Vandals actively tried to promote unity and cultural synthesis within the kingdom. It reviews surviving evidence for the actions and ideology of the kingdom: its coinage, royal titles, officially-sponsored poetry, and other articles that present the regime as it wanted to be seen. The government in Carthage undertook many actions unique among the western kingdoms, such as starting its own calendar and drawing on not only on Roman but preRoman (especially Carthaginian) scripts of power to legitimise itself, while at the same time barely engaging with the Vandals' pre-African heritage at all. This chapter examines the cultural implications of these and other unusual official acts, and argues that they represent the Vandal administration trying to create a sense of shared African identity that both Vandals and Romans could partake of. 


\section{Chapter One \\ Romans in barbarian clothing: Social role as ethnic identity}

As late as 533, when the first Byzantine troops disembarked on Africa's shores, Procopius was confident that there were two distinct groups of people living in the Vandal Kingdom: "Vandals" and "Libyans" ( 1 i $\beta v \varepsilon \varsigma$, Procopius' term for Romano-Africans).${ }^{91}$ This view was shared by the emperor and his government, who were confident enough in their ability to identify particular people as "Vandals" that they could pass legislation to have most such people deported from Africa.

The implication of this is that, even on the eve of the invasion, there were still sufficient differences in African society between a group of people called "Libyans" and another called "Vandals" that it was possible to pick out members of one group from the other. Much of modern scholarship has accepted the idea that there was a high degree of social and cultural segregation between the two groups: the Vandals as a closed and cloistered elite, ruling over a mass of disenfranchised Roman subjects, each maintaining separate language, culture, and identity, each existing in mutual opposition and antagonism. This is the same assumption that has generally been made about all of the post-Roman kingdoms in the west, from Gibbon's piling up of contrasts between the "peaceful and polished inhabitants of Gaul," speaking the "tongue of Virgil and Cicero," and their new Frankish overlords ("hairy and gigantic savages of the North... equally disgusting to the sight and to the smell," speaking in "harsh and unknown sounds"), ${ }^{92}$ to Ward-Perkins' description of the Ostrogoths in Italy as a "ruling race" exerting a colonialist and racial supremacy over the ItaloRomans comparable to the British Raj. ${ }^{93}$

However, the more one digs into the cultural fabric of the western kingdoms, the more this dichotomy begins to fall apart. Far from maintaining a splendid isolation from the culture of their new subjects, most of the western kings and their followers engaged with it to some degree or another, and even shared in it. One need only look at the thoroughly classicising actions of Theodoric, the first king of the Ostrogoths, for a clear example: during his reign, he rebuilt the Theatre of Pompey, reinstituted the grain dole in Rome, and issued a compilation of Roman law, ${ }^{94}$ to name but a few examples, and he was hailed as augustus by his Italo-Roman subjects in his own

91

Procopius, Wars 3.16.1-7. Although they played major roles in the Vandal Kingdom and Byzantine Africa (and indeed in Procopius' own narrative), both serving and fighting against the Vandal/Byzantine regimes, Procopius does not seem to have regarded the Berbers (or "Moors," as they are often referred to in scholarship) as a particular people of the Vandal Kingdom. The Berbers had a complex relationship with the Vandals, and both Vandal and Roman recognised a clear ethnic gap between the Berbers and themselves; Corippus, writing after the Byzantine conquest, appears to favour the Vandals over the Berbers as more cultured and less savage, Procopius writes that the Vandals incorporated all barbarian groups "exceptis Mauris" into their ranks, and it is worth noting that the only reference we have to an army unit in Vandal service specifically designated by ethnicity refers to Berber troops in the Vandals' Sardinian garrison. Berbers in Vandal service, as in Roman times, had their own rulers whose legitimacy derived from the Vandal throne, and who seem not to have been part of the Vandal state proper. Intriguingly, there is also patchy evidence for the survival of the Punic language out in the countryside, and Augustine refers to rural people who described themselves as "Chanani" (which some scholars have linked to "Canaanite," and thus possibly Phoenician/Punic), adding a further complication into the ethnic picture of Vandal Africa.

A full treatment of the relationships and barriers between Vandal, Roman, and Berber is beyond the scope of this thesis, but see Modéran (2003); Merrills (2004); von Rummel's chapter in Curta (2010). For an overview of the evidence for Punic and the Canaanites, see Conant (2012) pp.186-189.

92 Gibbon (1843), p.408.

93 Ward-Perkins (2005), p.65.

94 O'Donnell (2008), p.55. 
lifetime..$^{95}$ For all that their name has become a byword for pointless disfigurement and destruction of property, the Vandal kings, too, engaged constructively with Roman culture: they built bathhouses, sponsored classical learning, and patronised one of the most prolific literary scenes in late antiquity. Indeed, Procopius comments that their enthusiastic adoption of Roman pleasures and hobbies destroyed their fighting spirit and led, in the end, to their ruin. ${ }^{96}$

In such a light, the idea that there was a great and unbridgeable cultural gap between Vandal overlords and Roman subjects is difficult to sustain. This makes sense, as African Vandal culture had its genesis in a thoroughly Roman milieu. But it also raises difficulties. Cultural barriers such as language, dress, and literary or material culture have historically formed major strategies of distinction for many groups in many different time periods. The Vandals, however, display few to no distinguishing elements in these areas from the Romano-Africans that surrounded them. In just about every aspect of their social and cultural life, Vandals and Romano-Africans were indistinguishable. So how could Vandals be recognised and separated from Romans?

To answer this, we must identify what the indicia, the ethnic markers of Vandal and Roman identity, actually were, and how the boundaries around those indicia were maintained. They are not always obvious. Visible qualities like appearance, dress, and language are often markers of identity, for instance, but invisible qualities like religious affiliation or profession are also a possibility, and even things as abstract as political loyalty can be an indicium: witness, for instance, Abramson's discussion of loyalty to the regime as an indicium of ethnicity in Tang-dynasty China. ${ }^{97}$ We can pick up on a few of these less-visible indicia, in particular religion and certain legal rights and duties associated with armed service. The complicated subject of religion in Vandal Africa and its relationship to ethnic identity is discussed in Chapter Two; for now, we need only note the continued presence of Arians in Africa after the Vandals were deported, showing that religion could not have been the key trait that Byzantine authorities used to determine who was Vandal and who was not.

This chapter will demonstrate that the Vandals were hardly, if at all, distinct from the RomanoAfricans around them in terms of appearance or culture, and that the indicia that defined them most in the end were those of their role in society - soldiers - and the privileges they enjoyed as part of that role. It will examine the degree to which the two groups had fused, culturally speaking, by the time of the invasion, looking at self-identification, dress, art and poetry, language, profession, names, and physical appearance to demonstrate the ambiguities and lack of barrier maintenance on cultural grounds between Romano-African and Vandal. By exploring the available evidence for the relationship and barriers between Romano-Africans and Vandals along social lines, it will establish the metric by which they could, in the final picture, be separated out: the aforementioned profession of military service and its attendant social and legal privileges.

A first point to consider is the ways in which the two groups in Africa referred to themselves: after all, one of Smith's hallmarks of an ethnic group is, as discussed in Hall, a secure collective name. ${ }^{98}$ Throughout this thesis, I use the terms "Vandal" and "Romano-African" (or "Roman") to refer to the two ethnic groups of the Vandal Kingdom. However, these terms appear only infrequently in the kingdom's actual written record. Victor notwithstanding, and his account has an ideological slant that we cannot ignore, the word "Vandal" is mostly used in surviving African sources to describe members of the Hasding royal family; the term used most often for members of the wider social

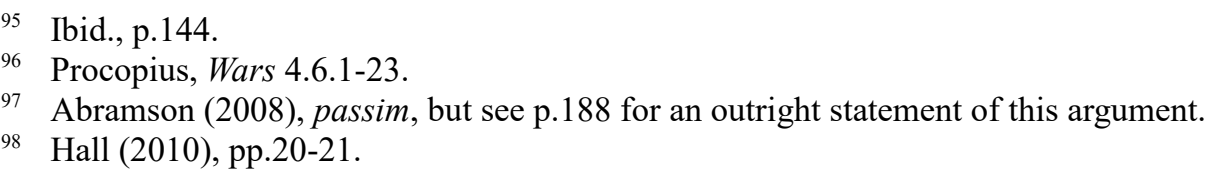


group is "barbarian." " Likewise, Roman writers from the kingdom rarely describe themselves as "Roman." Secular authors mostly seem to ignore the matter: it is largely left to Nicene polemicists to outwardly express their Roman identity. ${ }^{100}$ These authors, however, have their own agenda to push: Victor (and others, such as Quodvultdeus, bishop of Carthage during and after the Vandal invasion, and Fulgentius of Ruspe, theologian and bishop of Ruspe almost a century later) argue that the way to cling to one's Romanness is to hold on to Nicene faith, often using "Nicene" and "Roman" interchangeably in their writings. ${ }^{101}$ On the other hand, while the secular authors certainly continued to define themselves in very Roman terms, they expressed that cultural identity in decidedly local ways. Fabius Plancianus Fulgentius (a late-Vandal/early-Byzantine African mythographer, not identical with Fulgentius of Ruspe) appears to have viewed himself not as Roman but as a "Libicus," 102 much as Procopius identified the Romano-Africans as " $A i \beta v \varepsilon \varsigma . "$ Meanwhile, Luxorius possibly defined his poetic milieu as "punica," 103 and Corippus uses the term "Punic" to describe Romano-Africans in general. ${ }^{104}$

Conant argues that these authors might have avoided describing themselves as Roman out of a sense that claiming Roman identity might be interpreted by authorities as expressing loyalty to the Imperial government. ${ }^{105}$ However, given the degree to which the Vandals allowed pro-Nicene, antiArian, even anti-Vandal literature to circulate in their kingdom, ${ }^{106}$ it seems to me that their reluctance to refer to themselves as Roman cannot be based on this alone. The same clerical authors who referred to themselves frequently as Roman are not specifically punished for this (Victor, for instance, does not appear to have ever faced punishment for his work, and was even allowed to become bishop of Vita without trouble) ${ }^{107}$ which points to other motives, perhaps even genuine sentiment, for the secular authors' avoidance of the term. Given the degree to which identity is dialectically-constructed, it is extremely significant that the secular African literati do not, at any point in the surviving corpus of Vandal-era writing, profess a Roman identity, preferring more local and African forms. ${ }^{108}$ Abandoning the field of outward Roman identity may have been a tactical move on these authors' parts, but it left Roman identity in the kingdom to be largely defined on confessional, not cultural or literary grounds.

Did clothing form an indicium of Vandal identity? This is the impression given by a passage of the Historia Persecutionis, in which Victor describes the punishment meted out on courtiers who went from the palaces of the Vandals to Nicene churches "in habitu barbaro." 109 On its face, this passage suggests that there were cultural differences in clothing between Romans and Vandals; that there was such a thing as Vandal "national costume;" that it was possible for Romans to dress up "barbarian;" and that the Vandals tried to police this behaviour by punishing Romans for wearing "their" clothing. All the essential elements of boundary maintenance are here, which could lead one to conclude that costume formed a strategy of distinction between Roman and Vandal. But this interpretation raises unanswerable questions. Victor identifies the individuals being punished as Catholic, which he largely treats as synonymous with Roman; why then are they wearing Vandal clothing? And why would the Vandals prohibit them from wearing it at church, but permit them to

\footnotetext{
99 Whelan (2018), p.172. This occurs also in Ostrogothic Italy, where Goths outside the royal family are rarely identified as such: see Amory (1997), pp.464-465.

100 Conant (2012), pp.189-190.

101 Ibid., pp.190-192.

102 Fulgentius, preface to De Aetatibus mundi et hominis.

${ }_{103}$ Conant (2012), p.186.

${ }_{104}$ Corippus, Iohannis 3.277, 4.86.

105 Conant (2012), p.186.

106 Ibid., pp.174-176.

107 Moorhead (2006), p.xv.

108 Conant (2012), pp.186-187.

109 Victor Vitensis, Hist.Per. 2.8-9.
} 
wear it at their own palaces?

Victor's motives in the Historia are to draw a sharp line between "Roman" and "barbarian," and recent analyses ${ }^{110}$ of his work in this light have come up with a more plausible scenario: that "barbarian" clothing, in this context, may not mean a sort of Vandal national dress, but formal wear and badges of office worn in the context of the Vandal court. Archaeology and pictorial representations of aristocrats from Vandal Africa support this conclusion. The most famous lateantique African artwork, the Bordj-Djedid mosaic (fig.2), depicts a hunter on horseback. This rider's clothing, a loose tunic, long socks, and boots, has sometimes been identified as Victor's barbarian dress, but it is truthfully quite typical of Romans of this era and is found on, for instance, sixthcentury depictions of Roman soldiers in Ravenna. ${ }^{111}$ The tunic of the Bordj-Djedid rider, and of other artworks from Vandal Africa, ${ }^{112}$ is very similar to that worn by the Ostrogothic king Athalaric in the Diptych of Orestes (fig.3), which is itself identical to late-fifth- and sixth-century Roman military wear. ${ }^{113}$ Military fashion, such as short tunics, long socks, army cloaks, and large decorated brooches, increasingly filtered into civilian and especially official use during late antiquity. ${ }^{114}$ This style of clothing was associated by late-period authors with barbarians: Paul the Deacon, writing in eighth-century Italy, identified figures in (unknown) sixth-century frescoes wearing tunics, leggings, and long socks as Lombards, despite the fact that depictions exist from the same time of Roman soldiers in the exact same outfits. ${ }^{115}$ Meanwhile, figures like the Frankish king Childeric wore similar brooches to project Roman military-style authority. ${ }^{116}$ It may have looked "barbarian" to conventional Roman eyes, but the style of clothing in question was not foreign to the Empire at all. Likewise, so-called "barbarian-style" jewellery and other grave goods recovered from burials attributed to Vandals in Africa have turned out to be identical to those attributed to Romans in lateantique Spain and Gaul, which led von Rummel among others to conclude that these goods designate high status rather than ethnicity. ${ }^{117}$ The fact that no evidence for a "barbarian style" of costume or jewellery has emerged from Vandal-era graves in Africa (indeed, that artefacts recovered from high-status burials from the kingdom are identical to those from high-status Roman graves elsewhere in the West) suggests that, whatever this formal attire represented, it was not specific to the Vandal ethnicity.

We hear about Victor's "barbarian clothing" solely in the context of formal occasions (court and church). ${ }^{118}$ The complete lack of visual distinctiveness from anywhere else in the Mediterranean displayed in surviving Vandal-era grave goods and art argues against a particular Vandal national costume, and we know that military fashion percolated into civilian and official use in late antiquity, where contemporary commentators took it as "barbarian" in style. Thus, the "habitus barbarus" is likely the military-style clothing of courtiers and administrators, with badges of office and other late-antique official trappings. The scandal, in this light, is linked to the kingdom's religious politics; by wearing their official garb to officially-suppressed Nicene church services, the Roman courtiers are thus lending legitimacy to the Nicene Church in defiance of the Vandal state's official Arianism and demonstrating potential disloyalty. ${ }^{119}$ We will discuss this episode in more detail in Chapter Two. For now, we need only note that Victor's habitus barbarus does not indicate there was

\footnotetext{
110 e.g. von Rummel (2003) pp.131-141, Conant (2012), pp.60-61.

111 Conant (2012), p.61; Amory (1997), pp.342-343.

112 See von Rummel (2003), pp.138-140.

113 Amory (1997), pp.341-342.

114 Bowersock, Brown, Grabar (2012), p.349.

115 Ibid., pp.342-343.

116 Esmonde Cleary (2016), p.383.

117 von Rummel (2003) pp.134-137.

118 Conant (2012), p.61.

119 Burns, Jensen, Clarke (2014), p.72.
} 
such a thing as Vandal national costume, and the evidence we have weighs against it. In any case, as Maas notes, Victor's "shrill denunciations [of Romans wearing barbarian clothing, or of mingling with barbarians more generally] were necessary simply because their social integration had been so successful." 120 Victor would not have needed to try to draw so firm a line, or to heap condemnations on Romans who crossed it, if the boundaries between Vandals and Romans had not already significantly blurred. His mention of large numbers of Romans in "barbarian" dress negates the exclusivity of such dress to the "barbarians," and thus argues against the idea of costume as a barrier between the peoples. Despite Victor, then, clothing could not have been an indicium of ethnicity in Vandal Africa.

This lack of distinction or ethnic expression in clothing is mirrored in art. From what we know of their cultural expression and artistic tastes, the African Vandals kept little of their trans-Rhenish heritage. North and Conant maintain that the Vandals kept elements of non-Roman culture, even of old Germanic polytheism, during their rule in Africa, ${ }^{121}$ but the evidence for this is scant and ambiguous. Conant brings up archaeological evidence (animal bones) for horse-eating in Africa, offensive to Roman sensibilities but acceptable to Germans, ${ }^{122}$ but it is not certain that the bones in question are actually those of a horse (they might be a mule or donkey), and in any case they date from the time of a known famine, when people's standards about acceptable cuisine may have somewhat relaxed. ${ }^{123}$ North cites a couple of Luxorius' poems, in particular poem 292, an animalcentred poem (of a kind that North calls a "bestial novelty") about a tame boar that feeds at the dining table, which he links to the sacral nature of boars in Germanic worship. But there are many, much likelier ways to interpret the poem, and even North admits that "bestial novelties" are an old Latin poetic motif highly popular in late antique Carthage, with Luxorius himself writing several others. Other scholars have given multiple other interpretations of the poem, ${ }^{124}$ and there is no great reason to credit North's links of a boar in an otherwise wholly classical poem, by an otherwise wholly classical author, to sacrifices to Freyr or the boar of Valhalla. We need not assume an injection of non-Roman culture from this slender evidence when animal poems were in vogue in the Mediterranean as early as the reign of Domitian. ${ }^{125}$ If it demonstrates anything, it is that Luxorius' audience of elite Romano-Africans and Vandals enjoyed a poetic genre with roots stretching back into the imperial past, dwelling on themes and motifs familiar to any Latin writer. There is little evidence of non-Roman cultural affiliation to be found in a poem that displays such impeccably classical tastes.

Indeed, sometimes Vandal and Roman tastes can appear so similar that we cannot tell which identity an attested individual subscribes to. George's discussion on two poems from Luxorius, 46 and 84, highlights some of these ambiguities. ${ }^{126}$ The subjects of the poems are two aristocrats, Eugetus and Hoageis, being praised on similar terms for the luxury and tastefulness of their gardens. We are not certain who Eugetus was, but Hoageis, a Vandal prince, is a known figure. Based on the similarity of the two poems' themes, it has been suggested that Eugetus and Hoageis were the same person, but George argues otherwise: the two poems have different resonances, and the large number of garden representations in mosaics from Africa points to horticulture being a common theme in African art.

The difficulty of identifying the poems' subjects, regardless of whether one concludes they are two

\footnotetext{
${ }^{120}$ Maas (2015), p.270.

121 North (2015), passim.

122 Willems \& van Enckevort (2009), p.159.

123 Conant (2012), p.62 n.213.

124 e.g. Johnston (2016), p.501.

125 North (2015), pp.151-152.

126 Merrills (2004), pp.140-141.
} 
people or one Vandal, raises questions of how distinct the two peoples were. "If Eugetus is a Roman... then it is interesting that there is no apparent distinction between Roman and Vandal reflected in the poems, in way of life, power, wealth, or aspiration." ${ }^{127}$ Certainly the Vandals patronised Romano-African high culture extensively. Aristocrats with Vandal names commissioned classical poetry from Romano-African literati: Luxorius was commissioned by one Fridus to compose a cento from Virgil's poems to celebrate his wedding, ${ }^{128}$ which both tells us that Vandals could appreciate sophisticated classical poetry forms and suggests that the old Roman custom of reciting poetry at a wedding was still practised in Africa, even by Vandals. ${ }^{129}$ We also know that African writers flattered Vandals in classical terms: a Vandal count, Sigisteus, is directly compared to Achilles in a letter from Parthemius, a presbyter, and Prince Hoamer was apparently also known as the "Achilles of the Vandals." 130 There are numerous other poems and verses from the Latin Anthology whose dedicatees have non-Roman names: Hen's examples include an anonymous poem for the servus regius Abcar and a touching epitaph by Luxorius for Damira, deceased daughter of the above-mentioned Prince Hoageis. ${ }^{131}$ The theme continues in discussions of surviving Vandal art, such as the long debate over whether the rider of the Bordj-Djedid mosaic should be identified as Vandal or Roman. ${ }^{132}$ The difficulties of making a determination with certainty is another indicator that, from a cultural perspective, the two peoples of the Vandal Kingdom became very alike over the course of its history. Taken together, this suggests extensive cultural integration between the Vandals and the Romano-African elite, a thorough adoption of Roman elite culture by the Vandal aristocracy. ${ }^{133}$

Could language have formed a barrier between Vandal and Roman? Merrills assumes that language was a strategy of distinction between the two groups, but while that may be true in the kingdom's early years, it was probably no longer the case by the end of the fifth century, ${ }^{134}$ indeed, the early and frequent incorporation of Latin name elements into Vandalic names in the late fifth century suggests that the language was already declining in everyday use. ${ }^{135}$ Evidence for the survival of Vandalic in Africa is sparse; we have no Vandalic Bibles or commentary to match the Gothic texts produced in Ostrogothic Italy. Gothic was used as a liturgical language by the Ostrogoths, and there is evidence to suggest that the Arian Church in Africa used Vandalic in a similar manner: one of the few surviving Vandalic phrases left to us is the translation, from a Nicene source, of the ArianVandalic liturgical phrase "froia arme," "Lord, have mercy." 136 But Romano-Africans were encouraged, sometimes with threats, to attend Arian services, and most African Arian priests for whom we have any biographical information besides their name appear to be local and Roman in origin, at least after the initial occupation period, ${ }^{137}$ which argues against the church's use of Vandalic forming a strategy of distinction between Roman and Vandal. Surviving Arian sermons from the kingdom are in Latin, such as that of Fastidiosus against the Nicenes (included in a letter of Fulgentius of Ruspe). ${ }^{138}$ The evidence thus does not point to Vandalic being used as a lay tongue in church. The sermons were delivered in Latin to a Latin-speaking audience, with Vandalic used occasionally in the liturgy, much as Latin was used by the Catholic Church well into the twentieth century.

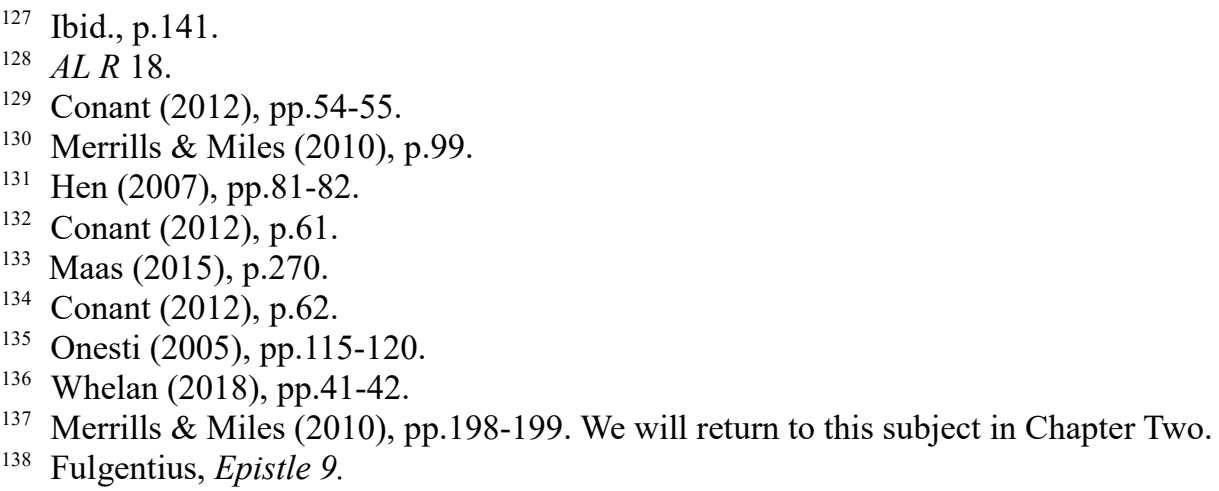


This aligns with evidence from the Ostrogothic Kingdom concerning the use of Gothic as a churchly tongue. While Biblical commentaries intended for consumption by Italian Arian priests were in Gothic, all surviving Arian sermons (intended for a lay audience) are in Latin, and in bilingual documents such as the Codex Brixianus, Latin predominates; the Codex's preface is written solely in Latin. This suggests that, while Italian Arian clergymen used Gothic as a scholarly and liturgical language amongst themselves, their sermons addressed a laity that spoke Latin, not Gothic. ${ }^{139}$ If the Italian Arian church primarily used Latin when speaking to its congregations, the African Arian church, more interested in outreach and missionary activity than its counterparts in other western kingdoms (to be discussed in Chapter Two), would have been under even greater pressure to do so. Even the Gothic Arian theological writings of Italy, the only major non-liturgical context in which Gothic occurs, have no equivalent in Africa: all surviving African Arian exegeses and theological works (such as Pseudo-Origen's Commentarius in Iob) are in Latin.

In the secular world, too, written Vandalic is glaringly absent. Vandal Africa produced reams of Latin poetry, including those dedicated to particular Vandal individuals. This suggests a Vandal audience that was conversant in Latin, capable of appreciating sophisticated Latin verse. Surviving legal documents from the kingdom, such as the Albertini Tablets, are all in Latin, and none of the titles and offices we know of in the kingdom derive from non-Latin languages: the official titles in Gothic like saio and gardingus that appear in Italy or Spain have no known mirror in Africa. On only one occasion does a title derived (presumably) from Vandalic appear: "Vandalirice," from an ekphrasis by Felix dedicated to Hilderic, ${ }^{140}$ is a Latin rendering of a Germanic compound word for "Vandal-king." 141 The context of this line, in a flattering court poem, is meant to emphasise the two crowns (one Roman and one Vandal) that Hilderic inherited, descended as he was from the Theodosian house as well as the Hasding line. "Vandali[ricus/rix]" is unattested among the royal titles (which we will return to in Chapter Three, along with this poem) in any official context, and the Vandalic language was in decline by Hilderic's time, ${ }^{142}$ so the likelihood that it was used on a day-to-day basis is low.

Other than that, the last possible written example of Vandalic left to us comes from an anonymous poem in the Latin Anthology:

\section{Inter "eils" Goticum "scapia matzia ia drincan!" non audet quisquam dignos edicere versus. ${ }^{143}$ \\ "Between the Gothic 'Hail!' and 'Let's get food and drink!' nobody dares to publish decent verses."}
"Gothic" in this case may
century Roman writers oft
labels "Goth" and "Gothic.'
some scholars treat the lin
Assuming these words are
139 Amory (1997), pp.247-50.
${ }_{140}$ AL R 215.
${ }^{141}$ Conant (2012), p.63.
142 Onesti (2005), p.124.
143 AL $R 285$.
144 e.g. Wars 3.2.2-8, Liber Genealogus 616 (which directly calls Geiseric "Gotice").
145 e.g. Traina \& Cameron (2011), p.82.
146 e.g. Chalon and Lassère (1985), pp.208-209.
147 e.g. Conant (2015), pp.63-64. 
language, but the extent to which the language was widespread among the population is difficult to say. If the poem's "Gothic" is not Vandalic, then its probable African composition is also suggestive. Chalons and Lassère advance the idea that (given that, while we know some Goths accompanied the Vandals into Africa, they were successfully incorporated into the Vandal body and effectively vanish from history) ${ }^{148}$ the Goths in question may well be the troop of soldiers who accompanied the Ostrogothic princess Amalafrida to Africa, as part of her dowry in her marriage to Thrasamund, fourth African Vandal king. ${ }^{149}$ We may thus be hearing an African poet, familiar with the Vandal presence in Africa, complaining about the sudden arrival of a whole troop of foreign Goths to an elite African audience. This elite audience likely contained both Romano-Africans and Vandals: Hen suggests that the poem may be a joke at the rude Goths' expense, applauding the Vandals' love of poetry as a distinguishing factor. ${ }^{150}$ In either case, given the flowering of Latin poetry in Africa under Vandal rule, and that these lines are themselves written in Latin verse, I agree with Conant and Hen in taking them as tongue-in-cheek, a joke that an elite, highly literary Romano-African and Vandal audience could share. ${ }^{151}$

This brings us to the end of all surviving evidence for Vandalic as a common spoken language in Africa. There are no Vandalic inscriptions and few references to anyone speaking it: most of these are in a clerical context. By itself, the absence of inscriptions suggests little. Vandal Africa's physical record is not vast, and its core territories remain under-excavated; the patchiness of the record does not rule out the existence of any such inscriptions. It is notable that the few contemporary objects we have that appear intended for royal use, such as a silver bowl with the legend "Geilamir rex Vandalorum et Alanorum," 152 are inscribed in Latin. Even objects that only a small circle around the king would ever have seen do not use Vandalic. While Vandalic may have spread as part of the liturgy, in all other contexts, its use was narrow.

Equally difficult to say is whether it formed any barrier between Vandals and Romans. The Historia Persecutionis mentions Cyrila, identified as "patriarcha Vandalorum (patriarch of the Vandals)" trying to pretend he cannot speak Latin to get out of speaking first in a debate with Nicene clerics. The Nicenes do not buy it, ${ }^{153}$ and neither should we, especially as Cyrila's particular role here is presiding over Huneric's high-profile conference in 484 between the Arians and the Nicenes. A figure chosen to head the Arian party in such a debate cannot plausibly have been unable to speak Latin, and Victor, as Whelan notes, had every reason to make the chief priest of his opponents look ridiculous (and uninspired by the voice of God, as bishops partaking in these debates were supposed to be). ${ }^{154}$ It cannot be ruled out that Victor invented this statement.

Extensive bilingualism has been regarded as the likeliest scenario in Vandal Africa, including by Merrills and Miles, ${ }^{155}$ and if the Vandalic language ever was used as a strategy of distinction, it no longer was by the sixth century. ${ }^{156}$ Certainly there are no difficulties in communication mentioned in Procopius' account of the invasion in any of the many instances of dialogue or letter-writing between Vandals and Byzantine soldiers. Whether or not Vandalic continued to be spoken in the Vandal army during the sixth century, and there is little reason to make assumptions either way, language itself did not form a significant barrier between Vandal and Roman.

${ }_{148}$ Merrills \& Miles (2010), p.84.

149 Chalons and Lassère (1985), pp.209-210.

${ }^{150}$ Hen (2007), p.82.

${ }_{151}$ Conant (2012), p.64; Hen (2007), p.82.

152 P.R.T., pp.445-447.

153 Victor Vitensis, Hist.Per. 2.55.

154 Whelan (2018), p.39.

155 Merrills \& Miles (2010), p.95; Conant (2012), p.63; Whelan (2018), p.41.

156 Conant (2012), p.62. 
Again, it may be revealing to draw a comparison with the better-attested kingdoms. We know from the Ostrogothic Kingdom that Italo-Roman adoption of Gothic was minimal, with only one Roman family on record as bothering to learn it: this makes sense, given that much recent scholarship has concluded that the Goths of Italy were, like the Vandals, a heterogeneous group including Goths, Gepids, Rugians, and Romans from Thrace and Illyricum. They spent a long time south of the Danube (thus, surrounded by an overwhelming mass of Latin-speakers, from which they evidently recruited) before settling in Italy, also home to a vast Latinate population. Also like the Vandals, the Goths acclimatised quickly to local Roman culture, including in the area of language. O'Donnell states "there is little to no evidence for Latinless Goths" 157 in the period of Gothic rule in Italy; the same could equally be said of the Vandals. As a heterogeneous military coalition, with Vandals, Goths, Alans, Sueves, and Romans in the mix, Geiseric's army would have needed a common language, and Latin was the only realistic possibility. Given the adoption of Romano-African elite cultural norms by the Vandals during their rule in Africa, and the continuing recruitment of Romans into the army while there, continued penetration of Latin into the Vandal army seems likely. Outside of the church, no evidence exists for Vandalic surviving as a spoken language into the sixth century, and Onesti concludes that it was near-extinct by the time of Justinian's invasion. ${ }^{158}$

Quite a few potential strategies of distinction have been brushed aside here. Language, material and literary culture, and costume, all markers used at various times to distinguish certain ethnic or religious groups from others, serve largely to blur and confuse the boundaries between Vandal and Roman in the Vandal Kingdom. A world in which Romans occasionally use Vandalic in the liturgy and Vandals are flattered with comparisons to Achilles is not one that suggests sharp cultural barriers. If, in terms of culture, Vandals were impossible to clearly distinguish from Romans in the climate of late Vandal Africa, what distinctions were there between the two groups?

Other ruling elites in the post-Roman West, such as Franks, Goths, and Burgundians, established legal codes that drew clear delineations between members of their group and their Roman subjects. While scholars like Ward-Perkins present them as un-Roman, these legal codes were in most respects continuations of Roman law. However, the fact remains that these groups held certain social and legal privileges over the Romans they ruled. The Vandals also enjoyed certain privileges over the Romano-Africans. Although no legal code from the Vandal Kingdom has survived to the present day, we can build a picture of these privileges based on non-legal sources like Victor.

Chief among the Vandals' social privileges was access to the so-called sortes Vandalorum, variously translated as "Vandal allotments," "shares," or "estates." We can infer from primary sources that this term referred to some variety of redistribution or change of ownership of land in the African provinces, organised by Geiseric for the benefit of his soldiers after their conquest of Carthage. A large-scale expropriation of plots of land from the Romano-African population and granting it to the arriving Vandals certainly happened after Geiseric's conquest of Africa. ${ }^{159}$ This also occurred elsewhere in the post-Roman West, such as in Ostrogothic Italy upon the arrival of Theodoric. ${ }^{160}$ Although the sortes are never explicitly equated with this expropriation, Procopius implies that is what they are in the Wars. ${ }^{161}$

Possession and inheritance of these sortes was a key privilege enjoyed by the Vandals over the Romano-Africans: unlike the old landowners in Africa, most of whom still remained (and formed a

\footnotetext{
157 O'Donnell (2009), p.121.

158 Onesti (2005), pp.115, 124.

159 Conant (2012), p.181.

160 Heather (2006), p.431.

161 Procopius, Wars 3.5.11-18.
} 
key part of the tax base), the Vandals did not have to pay rent on their land. This was for a practical purpose. Wealth from the Vandals' estates was used to support the military, tying them to the land and reducing the financial burden on the government of maintaining the army (substantial for the Roman state) to a minimum. ${ }^{162}$ As Vandal identity was partly defined by military service (a topic we will return to later in this chapter), possession of the rent-free land needed to support oneself as a soldier made ownership of such an estate integral to that military identity. But the estates may also have served as a strategy of distinction in their own right, with the legal and economic privileges that came from owning such an estate marking one out from the rest of the land-owning population, and possession of such a share marking one as a member of the elite. "Vandals," as Merrills puts it, "came to be identified with the people who lived on 'Vandal estates.""163

Owning a "Vandal estate," of course, implied that one was eligible for, and obligated to perform, military service, and one of the other chief strategies of distinction for the Vandals, as for other post-Roman western elites, was their status as soldiers (as opposed to civilians). ${ }^{164}$ Vandal identity was highly militarised: every male explicitly attested as a Vandal or barbarian in the Vandal Kingdom is a warrior of some kind. We have no reference to Vandals in civilian occupations: there are no Vandal charioteers, poets, or blacksmiths. Even Vandals presented in a civilian role, such as the landlord from Victor's account, have military status and trappings; he is identified as a millenarius, a commander of a thousand troops, with a particular affection for his armourer Martinianus (further indicating military affiliation). ${ }^{165}$ This Vandal landlord, assuming he was a real person, almost certainly managed his estates from afar: Salvian, the fifth-century Gallo-Roman author, says in De Gubernatio Dei that Vandals were city-dwellers, ${ }^{166}$ and we have little evidence for their settlement outside of Zeugitana ${ }^{167}$ and a few strategically-important garrisons. ${ }^{168}$ A striking example of this is Dracontius, a poet with possible Vandal parentage, ${ }^{169}$ who is never once referred to as "Vandal" in contemporary sources, and never claims the identity for himself, even when professing loyalty in the face of accusations of serving a foreign master or begging for clemency from the kings. The Historia Persecutionis likewise features Nicene Christians with Vandal names, bearing no military affiliation, such as the courtier Armogas, but Victor, obsessed though he is with drawing a line between Romans (who are Nicene by definition) and Vandals (always Arian), nevertheless regards Armogas as being on his side of the divide ("Armogastem nostrum"). ${ }^{170}$

To understand this divide between militarised Vandal identity and civilian non-Vandal status, it is helpful to draw comparisons between the Vandal Kingdom and other, better-understood post-Roman states. Although they emerged from different circumstances, the Ostrogoths of Italy, the Vandals' closest neighbours and the kingdom with which they interacted most extensively, had a similarly militarised identity. A product of Roman frontier policy in the post-Constantinian era, the Ostrogoths were drawn from a mix of Romanised immigrants, local Balkan peasants, and soldiers locked into their profession after Constantine's army reforms. ${ }^{171}$ As Theodoric travelled to Italy, his army picked up more Romans and other groups in Pannonia, and continued recruiting in Italy, ${ }^{172}$ all

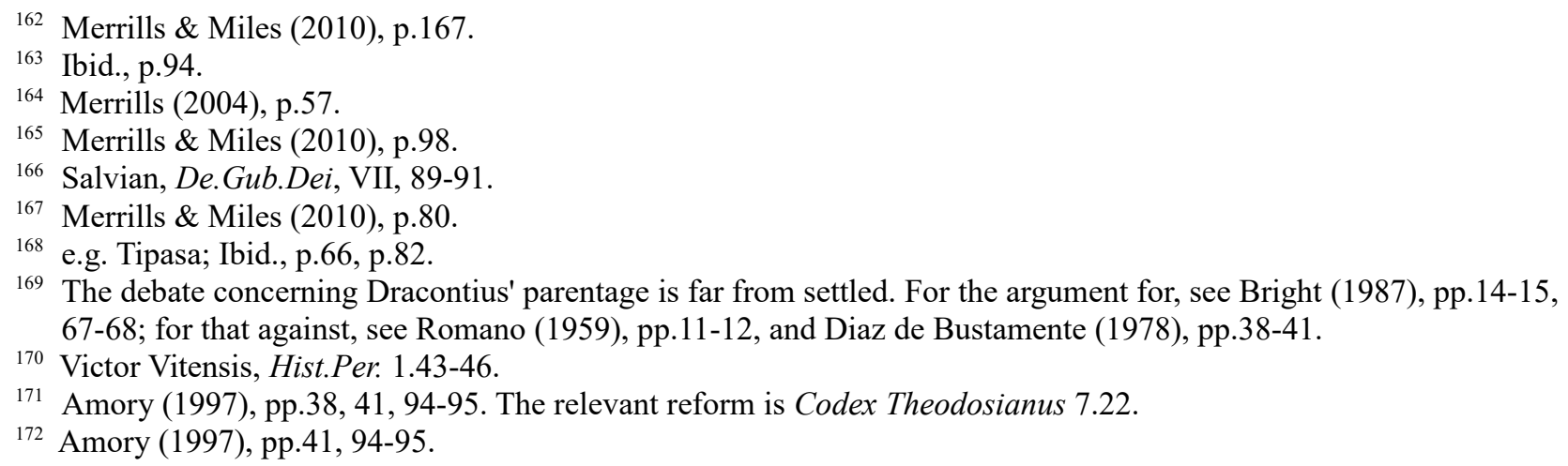


under the moniker "exercitus Gothorum." 173 Despite its ethnically varied character, the Ostrogothic army was conceived throughout the kingdom's lifespan as a Gothic institution. Although they recruited extensively from among Italo-Romans, ${ }^{174}$ the state ideology of the Ravennese administration divided the kingdom into civilian Romani ${ }^{175}$ and military Gothi ${ }^{176}$ Crucially, the Gothic army, and individual soldiers within it (regardless of origin), ${ }^{177}$ were collectively viewed as Goths. ${ }^{178}$ Indeed, if anyone ever legally challenged a Goth's social status, he could merely point to proof of his military service to protect himself, ${ }^{179}$ implying that Gothic identity and privileges were identical with, and based upon, service in the Gothic army. In this context, the militarised nature of Vandal identity makes perfect sense. Vandal identity, as with Gothic identity, was tied to armed service, to the point where even individuals of Vandal descent who did not pursue a military career, like Dracontius, were not seen as having Vandal status. Thus, many scholars have concluded that the major defining component of Vandal identity was armed service, ${ }^{180}$ a situation which neatly parallels that of the Goths.

Also similarly to the Ostrogoths, the Vandal army recruited wherever it went and successfully incorporated multiple armed groups into itself, both before and during its time in Africa. Opening up the army, a key Vandal strategy of distinction, to other ethnic groups had the effect of providing those groups with a pathway to assimilation into Vandal ethnic identity: Procopius tells us that "the names of the Alani and all the other barbarians, except the Moors, were united in the name of 'Vandals'," 181 and the evidence bears this out. We are told that Sueves and Alans accompanied the Vandals into Africa (as did certain Romans, to whom we will return), but by the fall of the kingdom, these groups all appear to have vanished. The last reference to a Sueve in the Vandal Kingdom is an epitaph from 474. ${ }^{182}$ Likewise, Gaggero's survey of all available attestations of Alans in Vandal Africa concludes that "la presenza alana nel Nordafrica vandalo non è risultata sufficientemente visibile," and that the Alans had been assimilated by Justinian's invasion: during the invasion and the subsequent Vandal insurgency, only Vandals are visible. ${ }^{183}$ Even individuals with Alanic names, such as Tzazon, ${ }^{184}$ brother of Gelimer, are identified by Procopius as Vandals. ${ }^{185}$ Indeed, Procopius also tells us that "by associating other barbarians with themselves, [the Vandals] came to be an exceedingly numerous people," these smaller ethnicities into their own ranks. By 533, the Sueve and Alan ethnicities in Africa appear totally assimilated into the Vandals.

Procopius only speaks of "barbarians" being united under the Vandal name: critically important to understanding social and ethnic roles in Vandal Africa, however, is the fact that this door was open to Romans too. The army that crossed into Africa contained within itself the Roman soldiers that the comes domesticorum Castinus had led against the Vandals in 422, converted to Vandal service after

173 Ibid., p.93.

174 e.g. Cassiodorus, Variae 1.40.

175 Amory (1997), pp.52-54, pp.59-60.

176 Ibid., p.79.

177 Ibid., pp.93-5.

178 For more detail on the ethnic-regimental groups in Theodoric's army, see Amory (1997), pp.93-4.

179 Wolfram (2005), p.121.

180 e.g. Conant (2012), pp.59-60; Merrills (2004), p.57.

181 Procopius, Wars 3.5.20-22.

182 The memorial for Ermengon, a Sueve woman ("Suava") in the Grand Basilica of Hippo (North (2015), p.157).

Merrills and Miles point out that her identification as a Sueve does not preclude a wider Vandal identity, and in any case there is debate over whether she was a native of Vandal Africa or an immigrant from the Suevic Kingdom in Galicia (Merrills \& Miles (2010), p.97).

${ }_{183}$ Gaggero (1996), pp.1641-1642.

184 Onesti (2005), pp.122.

185 Procopius, Wars 4.3.14.

186 Ibid., 3.5.19-20. 
Castinus' crushing defeat. ${ }^{187}$ Romans from Spain also came to Africa with Geiseric; in 435, not long after the first settlement between the newly-minted African Vandals and the Empire, Geiseric expelled from his court four high-ranking Hispano-Roman officials (and possibly other low-ranking ones) for refusing to convert to Arianism. ${ }^{188}$ Aside from this moment of tension, these Romans were fully a part of the Vandal army, wholly sublimated into the Vandal elite by the time of their arrival in Carthage. ${ }^{189}$ After their arrival, the Vandals continued to recruit new soldiers from the locals: Romano-Africans did join the Vandal military, ${ }^{190}$ just as their Italian counterparts could join the exercitus Gothorum, and this seems to have granted them the same legal rights as Vandals when it came to holding tax-free property. ${ }^{191}$ Army service and access to tax-free sortes were two of the most crucial markers of Vandal identity, and the fact that Romano-African soldiers could share in them is a strong indicator that Vandal identity could be conferred through military service. This situation is again mirrored in Italy, where the kings were quite willing to offer the local Romans the chance to "become Goths" by joining the army; according to Wolfram, "being a Goth, enjoying the 'freedom of the Goths', and marching in the Gothic army were one and the same thing," 192 and the same appears true of the Vandals.

Interpreting the Vandals as a late antique military culture may explain Dracontius' Latin name as well as his non-Vandal identity; military service in the Empire being hereditary by the 400s, the Goths, and the Roman army in the Balkans from which they came, practiced a naming strategy in which children destined for civilian posts were usually given conventional Roman names, while children destined for military roles were given non-Roman ones. A similar trend can be observed among conventional Romans, as there are many (usually military) figures identified as Roman in late antiquity who bear Germanic or other non-Roman names. ${ }^{193}$ Likewise, almost all named military individuals from the Vandal Kingdom bear non-Roman ones, while named individuals in the Vandal Kingdom with civilian roles, such as administrators, Arian priests, and literary figures (even those descended from Vandals, like Dracontius) generally bear Roman ones. This is evidence either of a sharp ethnic divide between military and civilian life or of a Vandal naming strategy similar to that of the Balkan armies. As we have seen, while the Vandal army was heavily associated with a particular ethnic identity, ethnicity was not itself a barrier to recruitment into the Vandal army, nor to receiving the privileges that came from service, and it could be imparted, from a social perspective, as part of taking on a military role. This implies that a Balkanesque naming strategy was in use among the people of Vandal Africa. Interestingly, one family named in the Historia Persecutionis (during the persecution, thus in Huneric's reign), consisting of a woman, her sister, and her son, contains conventional late Roman names for the women (Dativa and Dionysia) and a name combining a Latin prefix with a Germanic suffix for the son (Maioricus). ${ }^{194}$ The picture we have of Vandal-era families is highly incomplete, and we cannot extrapolate a great deal from this, but the presence of mixed names in this family is suggestive. Another example of this is Becca, a sixth-century aristocrat accused by Luxorius of sodomy. Becca is a Germanic name, but Luxorius' reference to wealth and inheritance from Becca's "grandfather and great-grandfathers and greatgreat-grandfathers" suggests a long history in Africa, and thus either Roman or mixed descent. ${ }^{195}$ Better understood western kingdoms, like that of the Franks, again help to point the way: we can trace a change in preferred names for the descendants of Lupus, duke of Champagne in the late

\footnotetext{
${ }_{187}$ Merrills \& Miles (2010), p.50.

188 Ibid., p.61.

189 Ibid., p.84.

190 Diesner (1967), pp.15, 21-23.

191 Conant (2012), p.142.

192 Wolfram (2005), 121-122.

193 Amory (2009), p.287.

194 Victor Vitensis, Hist.Per. 3.22-24.

195 Conant (2012), pp.52-53.
} 
sixth century (described by Venantius Fortunatus as from a Roman stirps) from Latin to Frankish, very likely accompanied by a change or flexibility in identity between Roman and Frank, ${ }^{196}$ and there are numerous similar examples of families with mixed names from the Frankish Kingdom around this time. ${ }^{197}$

A final indicium to consider is that of appearance. Although appearance is a common strategy of distinction, it is difficult to know what the Vandals looked like. At the start of Book 3 of the Wars, Procopius describes all "Gothic" peoples, in which the Vandals are included, as white-skinned, blonde-haired, and good-looking. ${ }^{198}$ Conant raises this as a possible indicium, but with reservations, and he is right to be cautious. ${ }^{199}$ These are standard topoi dragged out by late-antique authors to refer to northerners, be they Celtic, Germanic, Gothic, or later Slavic - the fair hair in particular recurs frequently, with stock phrases like "flava Germania" or " $\xi \alpha v \theta \grave{\alpha} \varepsilon$ है $\theta v \eta$ " common among lateantique writers, ${ }^{200}$ even as other authors argued against their universal application to northerners ${ }^{201}$ and we need not take them at face value. Even assuming all Vandals originally looked like this, though, it is a stretch to assume they still did by the time of Justinian's invasion. Our inability to determine the ethnicity of the Bordj-Djedid Rider is instructive here. The Vandals were not an exclusive group: they spent three decades within the Empire before they formed their kingdom, recruiting, as successful late-antique armed groups did, from local populations, and during this time they incorporated multiple other groups, including Alans, Sueves, Goths, Hispano-Romans, and the remains of a Roman army. ${ }^{202}$ They then spent a century in Africa, vastly outnumbered by the locals, and continued recruiting from them as well. ${ }^{203}$ It is improbable, then, that they were still as homogeneous as Procopius says, even if they were in the first place: he is likely deploying the common stock language of his time. At the very least, the picture is probably more complicated than he suggests, and Conant rightly points out that no African authors echo Procopius' notion that Vandals were physically distinct from Romans, even those trying to present the Vandals as alien and un-Roman (e.g. Victor). ${ }^{204}$ Given the dialectical nature of ethnicity construction, the absence of othering based on physical appearance in hostile Romano-African narratives suggests that appearance was not considered a distinguishing indicium in Vandal Africa.

What we see here is a complex social picture of late antique identity, a merger of peoples halffulfilled by the time of the invasion. The two categories of people identified by Procopius in Africa at the time of Justinian's conquest, "Vandals" and "Libyans" (in as much as either term had valence within the kingdom itself), existed as separate and meaningful terms referring to two distinguishable groups, but the nature of these two groups, and the differences that defined them, do not break down along lines of culture or costume, but of the role they played in society. In most respects, the Vandals were indistinguishable from the Romans they lived amongst, sharing with them their artistic and literary tastes, their preferred language, their manner of dress, and their values and pastimes. This commonality, as we have seen, was based on Roman norms. Where elements of nonRoman influence are apparent to us, such as in names, the Vandalic language, and Victor's habitus barbarus, both Romans and Vandals appear to hold them in common. Vandalic liturgical phrases come out of the mouths of Romano-African Arian priests, different families freely mix classical, Christian, and Vandal names (and individual names freely mix elements from different languages),

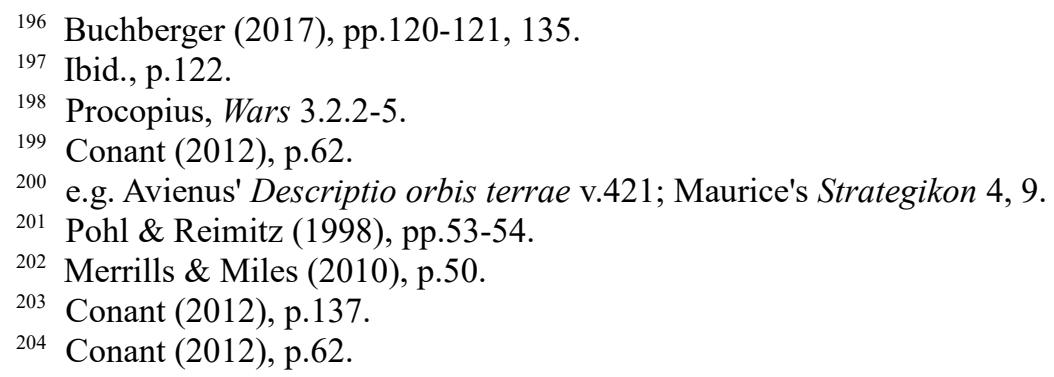


and Roman officials at court wear "barbarian clothing" with no one batting an eyelid.

Given the vast amount of shared culture between the two groups, and the known permeability of the major barrier between them (military service), it is apparent that they were well on the road to an eventual fusion. Direct evidence of such transformations is patchy in the Vandal Kingdom itself, but Becca's case is suggestive, and examples from other post-Roman kingdoms, such Duke Lupus and his children, point to the possibility. This process started early in Africa, perhaps due to the relatively early formation and independence of the Vandal Kingdom, and perhaps due to the Vandals' enthusiastic sponsoring of Roman culture (the process also advanced quickly under the Ostrogoths, a comparatively short-lived kingdom, but likewise headed by avid patrons of Roman classical culture). The fact that both ethnicities drew heavily from the same cultural milieu would have made crossing between them straightforward; "it seems likely that individuals could adopt different identities over their lifetime, and members of the same family might certainly change their principal affiliation over generations." 205 Although Merrills himself acknowledges that these is some controversy over this point in a footnote to this sentence, the steady erosion of distinctive indicia between the two peoples - the very strategies of distinction by which Vandals and other postRoman ruling elites maintained their group identities in an overwhelmingly Roman milieu throughout the kingdom's lifespan makes it a solid conclusion to draw. The Vandals, over the course of their rule in Africa, acculturated themselves into the Roman world, adopting the mores and tastes of the Romano-African elite with eagerness and ease. The germination of a post-migration Vandal identity in Africa, in a highly culturally-Roman climate, meant that the Vandals of the Vandal Kingdom came to define themselves in a specifically Roman context; thus Vandal and elite Romano-African tastes were familiar to and compatible with one another. The extent to which this process had been completed by the time of the invasion had made the Vandals indistinguishable, culturally-speaking, from the Roman elite they lived amongst. This blurring of lines between Vandal and Roman is supported by the confusion over the identity of Eugetus and Hoageis in Luxorius' poems; the continued debate over whether Eugetus is Roman or Vandal based on the rich tastes and exquisitely Roman hobbies Luxorius ascribes to him points towards George's complete or nearcomplete fusion of Vandal and elite Roman culture.

In other words, the two groups, Vandal and elite Romano-African, were indistinguishable from other according to almost every possible metric by which we might usually judge ethnicity. Distinguishing indicia such as language, naming patterns, or cultural norms had greatly broken down by the time of the invasion, with both groups sharing in aspects of both. At the same time, the other groups that had accompanied the Vandals into Africa - Alans, Sueves, Goths, and non-African Romans - had been absorbed into the greater body of the Vandals, leaving no traces for Belisarius to find. This lack of boundary maintenance created a culture of fusion in Vandal Africa, which had already digested these smaller groups, and had well advanced, if not completed, the process of dissolving the differences between Vandal and Roman on at least the elite level. We have seen that individual Romano-Africans could take on the key social indicia that defined Vandal identity (military service and possession of a tax-free estate, of the kind referred to in the kingdom as the sortes Vandalorum). Likewise, people of Vandal parentage who did not adopt these signifiers of Vandal identity, like Dracontius, were not regarded as Vandal by wider African society or, significantly, in their own writing. The meaningful ethnic boundaries between individuals considered Vandal and individuals who were not, as the evidence above shows, had little relation to birth (except in as far as military service in a post-Theodosian context was an inheritable profession), language, or culture. The relationship between Vandal identity and Arian confession will be discussed in Chapter Two, but we know that a great many Arians were left behind in Africa after the deportations, and measures taken by the imperial government concerning them caused

${ }^{205}$ Merrills \& Miles (2010), p.92. 
controversy in the province throughout the mid-sixth century. ${ }^{206}$ Thus, for now, we can put it aside as the defining indicium of Vandality in Belisarius' and Justinian's eyes.

This leaves us with one major indicium to consider, military service. "Significantly," Schwarcz writes, "it was as soldiers that the Vandals were deported by Justinian and used in his Persian Wars." "207 The Vandals' wives and daughters stayed behind, as did Arian priests and other functionaries of the Vandal state. No member of another profession is mentioned as being deported, or indeed is ever identified as a Vandal during the Vandal century. If Justinian and Procopius' notions of "deportation of the Vandals" only extended to soldiers, that implies very strongly that the general conception of a Vandal in that period of the kingdom's history was not of a nation of people but of a specific societal role; that is, that by the time of the invasion, the term "Vandals" meant "soldiers," and accordingly it was the kingdom's soldiers who were deported en masse after the invasion. This dovetails with the evidence that we have from after the invasion, in which the question of who was to inherit the land enjoyed by all the Vandal soldiers before they were deported became a major issue: we have no reference to any continued occupation by Romano-African soldiers of the sortes Vandalorum, despite knowing that the Vandal army recruited from amongst Romans and that Romano-African soldiers gained access to plots of tax-free land. There is a strong implication that Romano-Africans who joined the military and received privileges reserved for Vandals were lumped by the Byzantine provincial authorities into the Vandal identity and deported, rather than being allowed to stay in a "liberated" Africa along with the Romano-African civilian population. Likewise, although Justinian magnanimously awarded himself the victory title of Alanicus in addition to Vandalicus to celebrate Belisarius' successful campaign, no Alans (or any other ethnic group that crossed into Africa under Geiseric, for that matter) appear in Procopius or Corippus. The emperor likely took his inspiration from the occasionally-used Vandal royal title of rex Vandalorum et Alanorum, but (as we will discuss in Chapter Three) the existence of this dualethnic title, even its use by the last Vandal king Gelimer, is an invocation of the kingdom's glorious history, not a statement about its ethnic composition. Alans and Sueves lost their distinct characters and disappeared into the melting pot of the Vandal army long before 534; what evidence we have suggests that Romano-Africans who joined this army, thoroughly steeped in late Roman cultural norms, did likewise.

Our records for the holders of civilian administrative posts in Vandal Africa are scanty, but the few names and scraps of biographical information available to us confirm that Romano-African elites were the principal holders of such posts at the highest level. Individuals with non-Roman names occur more commonly as officials towards the end of the kingdom's life, but such figures are never identified, despite their names, as Vandals. But it was not merely in the governmental arena that we can see this stark division between civilian and military figures. Every individual identified as a Vandal, in our sources, is also identified as a military figure. Likewise, no non-military figure, no matter their name or profession, is ever identified as a Vandal. A clear line is thus drawn between military figures (who are Vandal) on the one hand and civilian figures (who are not) on the other both Vandals and Romans crossed those lines at times, but this seems to have led to a change in the socially-recognised identity of the individual in question, not an erosion of the barrier between the groups.

There are parallels between this situation and that of the Gothic regime in Italy. As described above, the Ostrogothic army recruited from a variety of different populations, but assimilated its recruits into the same umbrella of military identity. Wolfram notes the transformation of the Gothic army from a mishmash of various peoples under arms into "a general class of subjects bound to the king

\footnotetext{
206 Conant (2012), pp.320-321.

207 Merrills (2004), p.57.
} 
by an oath," 208 indicating the change of the meaning of the word "Goths," and of Gothic identity itself, from members of a particular ethnic group into people filling a specific social role (i.e. serving the state as soldiers). Italo-Romans, too, could join this warrior class, and in doing so take on the Gothic identity. In the end, the only meaningful social distinction between a Goth and an Italo-Roman during the Ostrogothic Kingdom's lifetime was their status as soldiers. All other proposed indicia, like language, personal grooming, or architecture, have been swept aside by recent analyses.

So too with the Vandals. As we have seen, the Vandals and the Romano-African elite had thoroughly blurred together by the time Belisarius' troops first landed on the African shore. In terms of culture, dress, and language, it is impossible to make a meaningful distinction between the two groups. And yet, Justinian's enforcers were able to separate out the one group from the other, and send them away to the Empire's battlefields in the East. We know that many Arians were left in Africa after this deportation, meaning that the regime did not determine Vandality along confessional lines; sheer descent and blood ties could not have picked them out either, since the wives and daughters of the Vandals were left behind, and there is no record of any attempt to pick out men descended from groups other than Vandals to exempt them from deportation. There is a tacit acceptance here by the Roman state of the self-defined nature of western military elites such as Ostrogoths and Vandals: being a member of one of these social groups was not a matter of blood but of social factors and choices, specifically their military status.

The only indicia left are military service and the social privileges, such as possession of a Vandal estate, that attended it. With the Goths and their exercitus Gothorum as a model, we may conclude that a major defining factor in being a Vandal was marching in the Vandal army. It was as a fighting class that the Vandals defined themselves, as a fighting class that they received their social and legal privileges, and as a fighting class that the Empire deported them and made use of them elsewhere. As happened with the Ostrogoths, and later the Visigoths, the Vandal Kingdom welded together a social class from a large variety of different peoples. Their early success in this has been buried under the rubble of Justinianic invasion, but the rediscovery by modern scholars of the advanced state of fusion between the Vandal and Romano-African upper class, and the opening of all the privileges and defining markers of Vandal rule to Romans who entered armed service, have allowed us to glimpse the dynamics of social and ethnic transformation taking place in the Vandal Kingdom before its end.

208 Wolfram (2005), p.121. 


\section{Chapter Two \\ Arriani quos nunc videmus multos seducunt: Religion, identity, and unity}

The idea that religion could unify peoples and nations as one was known in late antiquity. Western writers like Cassiodorus and Gregory of Tours believed it; emperors like Justinian believed it; and the Vandal kings certainly believed it. Adherence to the approved religion had increasingly come to be a defining indicator of loyalty in the eyes of many late-antique governments, from Rome to Persia. In these states, following state-endorsed creeds and religious forms was part of being a loyal citizen, while refusal to follow the approved religion marked one out as disloyal, subversive, perhaps even actively treasonous. Vandal Africa was no exception. Indeed, this assumption was at the very core of their religious policy, the largest and most sustained policy effort undertaken by the Vandal government that we know of. Problems with religion and loyalty dogged the Vandal state from start to finish. To combat those problems, the government attempted to spread its religion (by force if necessary) to all corners of the kingdom, enforced restrictions on the rights of religious subversives, and fostered the creation of a strong national church that could lend it support in times of trouble. This obsession with religion as the hallmark of a loyal citizen cut across ethnic lines: the halls of power were open to both Vandals and Romano-Africans, so long as they professed the correct faith. Likewise, both Romano-Africans and Vandals who professed a faith the regime regarded as heretical were barred from office and discriminated against, sometimes violently. It was religious confession, not ethnic identity, that provided the Vandal state with its chief litmus test as to who was loyal and worthy of office and who should be seen as suspect. When the kings tried to impose Arianism on their entire realm, it was with this aim of unifying their subjects under a national church in mind.

The Vandals thought strategically about religion. Jordanes tells us that they offered to become Nicene in Spain if the emperor agreed to help them against their enemies, ${ }^{209}$ while rumours survive to us from Hydatius, bishop of Aquae Flaviae in Gallaecia, that Geiseric had originally been a Nicene, but converted opportunistically to Arianism while in Spain. ${ }^{210}$ Whether we believe this rumour or not, it is true that Arianism offered the western kings a number of advantages: theological independence from Rome or Constantinople, for instance, or an opportunity to avail themselves of the same divinely-appointed status that the emperors enjoyed from their brand of Christianity, ${ }^{211}$ all of which made it an attractive proposition. The Vandal kings took advantage of their differing denomination and their power over African Nicenes to lever concessions out of the emperors on multiple occasions. For instance, when he was negotiating the marriage of Huneric to Eudocia, daughter of Valentinian III, Geiseric relaxed his restrictions on the Nicene Church enough to allow Deogratias to be appointed to the vacant bishop's throne of Carthage, ${ }^{212}$ while Huneric used the same technique to demand freedom of religion for Arians within the Eastern Empire. ${ }^{213}$ The kings advanced their own agendas with the emperors by placing pressure on their Nicene subjects: thus, Arianism made sense as a strategy from a diplomatic point of view.

Heather also suggests that the Vandals, and other western elites, saw in Arianism an opportunity to replicate the imperial model of an entwined church and state in a form that owed nothing to the Roman emperors themselves, allowing them to secure the same kind of loyalty on religious grounds

\footnotetext{
209

Merrills \& Miles (2010), p181.

${ }^{210}$ Hydatius, Chronicon 301.4

211 Heather (2007), p.145.

${ }^{212}$ Merrills \& Miles (2010), p.181.

213 Victor Vitensis, Hist.Per. 2.2-4.
} 
that the emperors enjoyed without making them dependent on either Constantinople or Rome. ${ }^{214}$ Religious affiliation was associated with loyalty across the late-antique world, from Rome to Persia, and Vandal Africa was no exception. The emperors commanded loyalty on religious as well as political grounds, owing to their role as defenders and promoters of Christian orthodoxy, and their definitions of what that orthodoxy was played a key role in defining what it meant to be a Roman. ${ }^{215}$ For heterogeneous coalitions like the Vandals, with a need to both cement their identity and enforce their dominance over local Romans,${ }^{216}$ this particular form of authority must have seemed very tempting. The curious appearance in Victor of a patriarcha Vandalorum indicates that the Vandals set up a head for their state church, a step unique in the Arian west. The Vandals took other steps to reorient their subjects' religious and cultural attentions away from the papal and imperial centres in Rome and Constantinople, towards Africa generally and Carthage in particular, ${ }^{217}$ and setting up an Arian patriarchate in Carthage, controllable by the kings, is well seen as part of this strategy.

In seeking to use religion to solidify their group identity and bind the Romans they ruled to themselves, the Vandals had no shortage of inspiration to draw from: writers across the West advanced similar conceptions of how universal religion could be used to bring disparate peoples together under a Christian state. In Africa's nearest neighbour, Italy, the illustrious senator Cassiodorus advanced the notion that a universal church could bring all the peoples of the world together as one Christian community, born from the single origin of baptism. ${ }^{218}$ Likewise, Gregory of Tours conceived of the unity of the Frankish Kingdom as based around Christianity, with the Frankish people merely one among many groups united in a Christian regnum. His History of the Franks elides much of the Franks' early history altogether, and presents Clovis, the first Frankish king to convert to Christianity, as the first proper king of the Franks. At the same time, he downplays Frankish identity after Clovis' conversion strongly, only occasionally mentioning the Franks: even at the moment of his baptism, Clovis is not described as Frankish, but as a

"Sicamber," thus disassociating the new ruler of the Christian regnum from any ethnic group that actually existed in his realm. The Franks are thus not the dominant people and culture of the new kingdom, but merely one group in a nation fundamentally united by Christianity. ${ }^{219}$ Isidore of Seville goes further: the peoples of Gothic Spain, in his mind, are not merely united by their faith but by the heresy of others, specifically the Byzantines, whom he others based on their stance on the Three Chapters as Acefali, contrasting them with the real Christians (Gothic or Hispano-Roman) of Spain. ${ }^{220}$ This controversy, which divided Hispano-Romans (and Romano-Africans, as we will see in the conclusion) from easterners on religious lines, is exploited by Isidore to divide them on ethnic lines as well: his work tries to orient Hispano-Romans away from identification with the Eastern Romans, towards the Visigoths, whom he portrays as stout defenders of orthodoxy. Just as the right religion could bring different peoples together, the wrong religion might create alterity between them.

All these men had Nicene Christianity in mind when they made their assertions, but although Cassiodorus dismisses Arianism as "debased religious practice" that rules its practitioner out from being a proper Christian king, ${ }^{221}$ if one disregards that assumption, the model of a state and people unified by religion could apply just as easily to Arianism as well. The Vandals were certainly concerned with the unity of their state. Securing their peoples' loyalty was a priority for the kings.

\footnotetext{
${ }^{214}$ Heather (2007), p.145.

215 Kahlos (2009), p.106.

216 Brakke, Deliyannis, Watts (2012), p.252.

217 These efforts are discussed in Chapter Three.

218 S.o.I., pp.186-189.

219 Ibid., pp.273-278.

220 P.R.T., pp.125-168 passim.

221 S.o.I., pp. 191.
} 
Thrasamund introduced annual oaths of loyalty, ${ }^{222}$ the kings appear to have redirected the remnants of civic emperor veneration onto themselves, ${ }^{223}$ and Dracontius was imprisoned for years for writing a poem under Gunthamund, third Vandal king in Africa, in praise of an "unknown ruler," 224 and thus appearing politically suspect. Perceived loyalty to the regime occasioned responsibilities and reward, as in the case of Godas, appointed governor of Sardinia under Gelimer. Godas would rebel and try to make a deal with the invading Byzantines, and thus was not the best choice, all things considered, but it was his quality of apparent loyalty that initially recommended him to the king. ${ }^{225}$ Although Godas' loyalty was only skin-deep, his example shows us that loyalty was a strong consideration in the kings' decisions on who to advance to high office, and Romans too could gain position in the kingdom by evincing their loyalty. ${ }^{226}$

This preoccupation with loyalty was a major consideration in the religious strategy of the Vandal kings. Throughout late antiquity, practice of the correct religion grew more and more associated with loyalty to the regime. In the Eastern Empire, orthodox religion became increasingly linked with loyalty to the emperor and the regime during the fifth century. ${ }^{227}$ Participation in public religious rites and approved civic cults had always been associated with loyalty to the emperor, ${ }^{228}$ and the rise of Christianity to sole approved religion of the Empire did not change this. Early in the fifth century, the Imperial government began to assign itself a role as protector and promulgator of the "proper" Christian faith. ${ }^{229}$ Imperial authority became linked with upholding religious orthodoxy and conducting missions to spread the faith in barbarian, unsaved lands (which had previously been the province of individuals, perhaps directed by church authorities, but not the Roman state itself). ${ }^{230}$ In turn, the form of orthodoxy enforced at home and promoted abroad by the emperors became linked to conceptions of what it meant to be a Roman and part of the Empire. Just as confessing the approved faith became a key marker of political loyalty, professing a non-approved form of Christianity or a non-Christian faith became suspect, even evidence of dissidence and disloyalty. ${ }^{231}$ Heretics and pagans were banned from imperial service in 417; Jews were similarly banned from military service in 418 and the entire imperial service in $438 .^{232}$ This process continued to advance through the sixth and into the seventh century, with emperors increasingly demanding religious conformity as a sign of loyalty to the Roman state, ${ }^{233}$ and adherence to the forms of Christianity approved by the emperor becoming increasingly associated by Roman citizens with loyalty to the Empire. ${ }^{234}$ Increasingly throughout the late-antique period, then, orthodoxy became linked to loyalty to the emperor and the Roman state.

This concept was shared by Rome's neighbours. It was with a view towards loyalty and dissent that the Sassanid Persian Empire (not Christian at all, but Zoroastrian) supported so-called Nestorian Christianity, to keep Mesopotamian Christians, present in large numbers along the vital frontier with Rome, from identifying their interests with the Christian Roman Empire. After Zeno closed their

\footnotetext{
${ }^{222}$ Merrills \& Miles (2010), p.72.

223 Ibid., pp.212-213. More on this in Chapter Three.

224 Often interpreted as a reference to a foreign ruler such as Theodoric or Zeno, but Merrills interprets it as a reference to Huneric, Gunthamund's predecessor, who came to power in a questionably legitimate manner, purged the royal family extensively, and opposed Gunthamund's branch of the family in particular. See ibid., pp.152-162.

${ }_{225}$ Procopius, Wars 1.10.25-33.

226 Conant (2012), p.61.

227 Kahlos (2009), p.106.

${ }^{228}$ Ibid., p.14.

229 Ibid., p. 106.

${ }^{230}$ Johnson (2016), p.68.

231 Kahlos (2009), p.106.

${ }^{232}$ Cohen (2008), p.35.

${ }^{233}$ Conant (2012), pp.361, 377.

${ }^{234}$ Kahlos (2009), p.106.
} 
schools in Edessa in 489, Nestorian theologians and clerics, including their most famous teacher Barsumas, crossed the border to join Christian communities in Sassanid Mesopotamia (which had enjoyed a long relationship with the Edessan school, due to their proximity). ${ }^{235}$ Barsumas spent a great deal of effort persuading the Sassanid monarchs of the connection between adherence to Nestorianism and loyalty to the Persian Empire, and conversely the traitorous, pro-Roman nature of rival sects. ${ }^{236}$ The Sassanids thus lent support to the doctrine, helping the Nestorians build their community not merely in Mesopotamia but throughout their Empire, effectively making it a second state church alongside the Zoroastrian Church. ${ }^{237}$ This prompted a reciprocal hostile evaluation of Nestorians in the Roman Empire, in which they became regarded and condemned as pro-Persian. ${ }^{238}$

A similar association between religion and loyalty is apparent in the Vandal Kingdom. Like Romans in the East, Africans, especially those closely associated with the regime, were expected and obliged to participate in state-approved religion (i.e. Arianism). Arianism was a part of the state's definition of a loyal citizen who could be entrusted with power and responsibility, and adoption of Arian religion was read by both Vandals and Romano-Africans as a statement of loyalty to the Vandal order. ${ }^{239}$ The Vandal kings took this further than most western monarchs (such as the Ostrogoths, who were happy to let Nicene figures like Cassiodorus wield state power): starting with Geiseric, Vandal rulers repeatedly issued legislation banning Nicenes from holding office. ${ }^{240}$ Likewise, they issued laws restricting Nicene legal rights, imitating Roman legislation against the Donatists. ${ }^{241}$ On the other hand, they offered status and temporal power to those who embraced the new faith: Victor mentions Nicenes being offered money, rank, and other rewards to embrace Arianism. ${ }^{242}$ While Victor's Nicenes nobly refuse and are punished for it, we learn from Quodvultdeus that this refusal was far from universal. He openly frets about Arians "whom we now see seducing many with temporal power," ${ }^{243}$ a clear indication that many Nicene Africans were not so staunch in their faith as Victor would like us to believe. Conversion to Arianism in Africa was sealed with rebaptism, a practice not generally associated with Arianism ${ }^{244}$ but with a long history in Africa. Associated in the fifth century with Donatist opposition to imperially-sanctioned Caecilianism, it had been a local tradition with strong support since much earlier times: well before the Arian regime or even the Donatist controversy in Africa, Cyprian, a third-century bishop of Carthage, defended African rebaptism against the bishop of Rome himself. ${ }^{245}$

This rebaptism was carried out en masse across Africa during Huneric's persecution, by force if necessary; Victor tells us that the regime even issued tickets confirming that an individual had been rebaptised as Arian, without which they were not allowed to travel anywhere. ${ }^{246}$ Nicene voices were divided on whether forced rebaptism was ineffectual or a kind of spiritual murder, ${ }^{247}$ but in the eyes of the Vandal government, it appears to have sealed the subject as an Arian, and given the weight

235 Deanesly (1991), p.5.

236 Dignas \& Winter (2012), pp.226-227.

237 Ibid., p.36.

238 Deanesly (1991), p.5.

239 Conant (2012), pp.61-62.

240 Victor Vitensis, Hist.Per. 1.43. Huneric and Thrasamund repeated this legislation.

241 Brakke, Deliyannis, Watts (2012), p.250.

242 e.g. Saturus, Hist.Per. $1.48-50$.

243 Brakke, Deliyannis, Watts (2012), p.247.

244 Ibid., p.248.

245 Ibid., pp.252-253.

246 Victor Vitensis, Hist.Per. 3.45-52.

247 Victor considers it harmless if done against one's will (Hist.Per. 3.49), while one pro-Nicene song (a common form of religious agitation in Africa; see Shaw (2011), chapter 10) exclaims "When Christ has restored a man to life by baptism, why does the Arian kill him again by rebaptism? Be ashamed, be ashamed, o heretic!" (Brakke, Deliyannis, Watts (2012), pp.247-248) 
that Quodvultdeus attached to it, some ordinary people (even those forced into it) may have seen it that way as well. ${ }^{248}$ While Victor is scornful of the practice having any effect, he does tell us that "the less intelligent and the ignorant thought that because of [their forceful rebaptism] they were guilty of defilement from sacrilege," 249 which tells us that many regular Africans took it seriously. This ritual gesture, from a decidedly African milieu, involved in coming over to the kingdom's approved religion restored travel rights to the new convert and could be accompanied with status and other rewards. Indeed, Arianism was a requirement for high status and office, which tells us that the kingdom thought those who persisted in the Nicene faith were politically suspect, and those who had been rebaptised as Arian, a ritual gesture that many Africans took very seriously, ${ }^{250}$ were perceived as more loyal and trustworthy. The halls of power were open to both Vandals and Romano-Africans, provided they professed the correct faith.

These strong links between the Arian church and the Vandal government led Nicene African polemicists to cast Arian clerics as a bloc of royal puppets, opportunists and flatterers grasping after state power. While Berndt rightfully dismisses the latter claim, the Arian church was heavily implicated in state politics - as normal for antiquity ${ }^{251}$ - and the kings were in turn involved in the promotion and protection of the church in Africa (but also abroad, as we shall see in Chapter Three). The creation of a Carthaginian patriarchate and the establishment of a national church structure $^{252}$ allowed the Vandals to exert a similar influence over their national religion as the emperors did in the east. ${ }^{253}$ In the few instances in which we see Cyrila, patriarch under Huneric, he is generally acting as the king's proxy in matters of religion, ${ }^{254}$ and at points Huneric directly draws attention to "his ability to centralise religious decisions based on imperial precedents." ${ }^{255}$ Royal prerogative and patronage thus shaped and sustained the African Arian Church.

In difficult times, the Arian Church reciprocated this patronage, helping to keep the state together in times of trouble and secure the loyalty of the kingdom's elite for pious Arian rulers. Pseudo-Origen, anonymous author of the Commentarius in Iob and one of the few African Arian voices surviving to us, militates against Nicene advisors in court under the relatively tolerant Hilderic (fifth king of Vandal Africa), arguing in favour of a hardline stance (represented by the exiled Amalafrida, Thrasamund's widow and associated with the hardline faction, whom Pseudo-Origen sympathetically allegorises in the figure of Job's destitute wife). ${ }^{256} \mathrm{He}$ urges pro-Arian courtiers, temporarily out of favour, to remain loyal to one another and await the restoration of their privileges. This indeed happened under Gelimer, who overthrew Hilderic in civil war. This sense of loyalty to a hardline-Arian royal faction shows that religious authorities were willing to help prop up the monarchy and encourage its subjects to be loyal, provided it was a monarchy that showed them favour. Patronage of Arianism was thus a strategy that helped the pro-Arian kings cement their power and command loyalty at home.

The inverse idea, that non-Arians were disloyal and untrustworthy, also plays out in the Vandal Kingdom. We have concrete examples of Africans closely-tied to the regime being punished for not

248 Ibid., pp.247-248.

249 Victor Vitensis, Hist.Per. 3.48.

250 Burns, Jensen, Clarke (2014), p.72.

251 Berndt \& Steinacher (2010), pp.248-249.

${ }^{252}$ We can detect hints of this in the surviving sources: various Arian priests are referred to as bishops, deacons, presbyters, and so on, suggesting that the Arian Church in Africa was organised in a hierarchy closer to the Nicene Church than the more informal, court-centric structures that appear to have predominated in other western Arian churches. See Whelan (2018), pp.43-46.

253 Nofziger (2012), pp.124-125.

254 e.g. his presidency over Huneric's staged debate of 484 (Victor Vitensis, Hist.Per. 2.53).

255 Nofziger (2012), p.125.

256 Dossey (2013), pp.118-121. 
participating in Arianism. Officials and governors might lose their posts for refusing to renounce Nicene belief, such as Victorinianus of Hadrumetum, Proconsul of Zeugitana (thus, holder of one of the most powerful offices of civilian government in the kingdom) under Huneric, ${ }^{257}$ or Saturus, a Nicene superintendent in Geiseric's household, who was offered the choice of conversion and reward or having all his property confiscated and his wife married to a camel driver (he refused to convert and became a beggar). ${ }^{258}$ The most notorious example of this is the "habitus barbarus" incident covered in Chapter One. To recap: Victor speaks of large numbers of people (identified as "Catholics," not as Romans, but there is not much of a distinction in Victor's eyes) being punished with torture for the crime of entering Nicene churches while "dressed like Vandals." Their crime is not wearing "barbarian clothing" per se, as he tells us that they came dressed in this way from the royal household (where presumably their attire caused no trouble), but specifically wearing it into a Nicene church. ${ }^{259}$

As discussed in Chapter One, the evidence we have does not suggest the existence of a distinct Vandal style of clothing, and the habitus barbarus probably represents military-style fashion of a kind widespread during the late-antique period (and associated with barbarism by Roman authors). ${ }^{260}$ What we have here, then, is courtiers leaving the palace and visiting their chosen place of worship, still wearing their official attire. Given the link between religious affiliation and loyalty in late antiquity, the curious nature of Huneric's prohibition on wearing "barbarian dress" to Nicene services, and the punishment the Nicenes received for doing so, becomes clearer. With Nicene Christianity so associated with loyalty to the Roman state, any performance of Nicene belief on the part of individuals associated with the royal court might have been a sign of disloyalty. The previous king Geiseric had already demanded that anyone serving the royal household convert to Arianism, ordering their rebaptism, a serious step which both Arians and Nicenes regarded as having great symbolic weight. ${ }^{261}$ When people in attire associated with the court, a theoretically Arian institution, visited Nicene churches (tolerated, at this point in Huneric's reign, but not approved of), it not only lent legitimacy to the Nicenes at the Arian Church's expense, but it also made the loyalty of those officials suspect.

Problems with religion and loyalty dogged the Vandal state from start to finish: the Aures Revolt of 483-484, in which Masties, the Nicene Berber client-king governing the Aures Mountains of inland Numidia in the name of the Vandals, broke away and established himself as an independent ruler, has been linked by Merrills to Huneric's anti-Nicene persecutions from around the same time. ${ }^{262}$ Likewise, Procopius tells us of a Nicene landowner named Pudentius who co-ordinated with Justinian to launch a large uprising against the Vandals in Tripolitania at the same time as the Byzantine invasion. ${ }^{263}$ Not only was approved religion a key indicator of loyalty in Vandal Africa, confession of a different faith was a marker of disloyalty, one that made itself manifest multiple times during the kingdom's lifespan. In such a climate, it is no wonder that the attendance of courtiers and officials, individuals trusted by the state, at churches linked to disloyalty and treason provoked such a harsh response on Huneric's part. This may also be explained by the fact that Huneric's reign was an unsteady one, harried by internal troubles: similar behaviour broke out in the Eastern Empire during the seventh century, in the apocalyptic final war with Persia and subsequent Muslim conquest of Syria and Egypt, with imperial authorities ordering the baptism of Jews and

\footnotetext{
257 Merrills \& Miles (2010), p.81.

258 Victor Vitensis, Hist.Per. 1.48-50.

259 Ibid., 2.8-9.

260 Amory (1997), p.341.

261 Burns, Jensen, Clarke (2014), p.72.

262 Merrills \& Miles (2010), pp.127-128.

263 Procopius, Wars 3.10.24-28.
} 
accusing those who did not obey of disloyalty to the emperors. ${ }^{264}$ As in the Empire, times of crisis sharpened these tensions in the Vandal Kingdom, but they never went away. Even in relatively secure periods, a king might bar Nicenes from serving in the army, owning a ship, or any other profession where a potentially-treasonous individual might do harm. ${ }^{265} \mathrm{Just}$ as professing the right faith opened doors to status and power for both Romano-Africans and Vandals, members of either ethnicity who professed a faith the regime regarded as heretical were barred from office and discriminated against, sometimes violently.

But more than political loyalty was at stake here. Throughout late antiquity, religious affiliation and ethnic identity became increasingly intertwined. The rise of Christianity universalised religion and made it a part of one's identity in a way that it had not generally been before in the Mediterranean world. ${ }^{266}$ This internalisation of religion naturally had an impact on the way people saw themselves and each other. Religion mattered for personal and group identity in a way it previously had not. Adherence to Christianity, and later to specific forms, creeds, and councils of Christianity, such as the Nicene Creed, the Chalcedonian doctrine, or Caecilianism (depending on exactly which other creed or sect one was contrasting oneself with), became by the sixth century integral indicia of Roman identity, ${ }^{267}$ strategies by which Romans could identify one another and distinguish themselves from other peoples. Likewise, certain communities within or around the Roman Empire came to use different religions, forms, or creeds to maintain their own identities in the face of pressure from Roman authorities and Roman cultural dominance (a strategy of distinction, as Pohl would put it). ${ }^{268}$

In a milieu in which religious affiliation was heavily tied to ethnic identity, governmental promotion of a particular confession has implications for ethnicity. In Roman society, there was a clear link between accepting the approved forms of Christianity and accepting Romanitas, ${ }^{269}$ and conversion could change the way in which someone's ethnicity was perceived. We have a tombstone from Lyons which reads "germine barbarico nati, sed fonte renati" ("born of barbarian stock, but reborn in the font"), testifying to the idea that one could lose one's barbarian nature through conversion to the "right" faith. ${ }^{270}$ Victor himself argued that the thing that unified all Romans across the Mediterranean, that made them a distinct people from everyone else, was their adherence to Nicene Christianity. ${ }^{271}$ This was a view shared by the post-Theodosian emperors, who increasingly came to associate Romanitas and orthodox Christian worship. In the eyes of the fifth-century imperial government, as Kahlos puts it, "to confess the correct version of Christianity had become synonymous with being Roman." ${ }^{272}$ The connection between religion and ethnicity is thus explicit. The approved form of Christianity was a key indicium of Roman identity, ${ }^{273}$ so much so that it allowed Roman identity to survive in the absence of the Roman state. ${ }^{274}$ Likewise, communities wishing to distinguish themselves from the Roman Empire or from Romans more generally often embraced alternative denominations or sects.

The Vandal government's promotion of Arian Christianity among its subjects cannot be understood

264 Conant (2012), p.354.

265 Conant (2012), p.168.

266 Rebillard \& Rupke (2015), pp.14-26.

267 Mitchell \& Greatrex (2000), p. 277.

268 For instance: Jewish identity in late antiquity and the middle ages (Gantner, Payne, Pohl (2016), pp.393-394); Egyptian identity in Byzantine Egypt (Bagnall (2010), pp.442-443).

269 James (2015), pp.127-128.

270 Mitchell \& Greatrex (2000), p.278.

271 See Conant (2012) p.192.

${ }^{272}$ Kahlos (2009), p.106.

273 Mitchell \& Greatrex (2000), p.277.

274 Conant (2012), p.375. 
independently from this identification between religion, loyalty, and identity. Alongside many of the late-antique Western elites, the Vandals professed the Arian faith. But the particulars of the situation in the Vandal Kingdom are markedly different than in the other Western kingdoms. The active missionary policy pursued by the Vandal kings stands in contrast to the benign, generally tolerant non-interference we see elsewhere in the West, with very different implications for identity.

When the Arian military elites who came to rule the post-Roman West arrived and settled in Spain, Italy, or Africa, they were met by local communities of Roman Arians. These Arian minorities had been differentiating themselves from the Nicene majority for years as a church of saints, a small elect group that survived in a sea of Nicene unbelief, ${ }^{275}$ preserving with pride the knowledge that it had been they, not the Nicenes, who evangelised the barbarians. ${ }^{276}$ On the arrival of the Arian military elites, as we can see with the Arian Church in Italy, the native Arian church and that of the new rulers merged into a single body, based on shared traditions and belief. ${ }^{277}$ These new hybrid churches were Latinate, rooted in local traditions, but associated with the crown and the identity of the new rulers, generally employing their language in at least some ecclesiastical contexts. ${ }^{278}$ Despite its previous existence as a local non-Gothic Arian community, the Italian Arian Church came to define itself as Gothic after Theodoric's arrival. ${ }^{279}$ Arian priests and churches in Italy are frequently referred to even by themselves as "Gothorum," 280 indicating a sense that the Arian denomination was seen as coterminous with the Goths (no matter how true that identification really was).

In most of the Western kingdoms, the ruling elites made no attempt to spread their faith further than this. The Burgundians and Ostrogoths (for instance) were content to leave things as they were, with one church catering to Nicenes and one to Arians, and the two existing in a sometimes-tense tandem. We have no record of most post-Roman rulers carrying out any kind of missionary activity among their new subjects, and Pohl's concept of strategies of distinction gives us an answer as to why: Arianism was a key indicium for almost all of the Western barbarians, ${ }^{281}$ and by maintaining the boundary between Nicene and Arian, the rulers were maintaining their own distinct identities as well.

In Vandal Africa, however, while the merger between the local and the outsider Arian churches happened as it did elsewhere, differences quickly began to arise. Some scholars, in particular Wolfgang Haubrich, have tried to interpret African Arianism as an ethnic religion exclusive to the Vandals, serving as a strategy of distinction as it did for the other western elites. Haubrich interprets the Arian patriarch Cyrila's enigmatic statement about being unable to speak Latin during the debate of $484^{282}$ in this vein as a statement of ethnic pride, presenting the African Arian Church as a specifically Vandal institution. ${ }^{283}$ But almost from the kingdom's birth, Geiseric set out to impose Arianism on his subjects (he was conducting missionary activity in Sicily even before the island was under his full control, for instance), ${ }^{284}$ and the Historia Persecutionis provides ample testimony for his successor Huneric's attempts to suppress the Nicene Church and convert his whole kingdom to Arianism. Victor also preserves an edict from Huneric ordering that all people in the Vandal

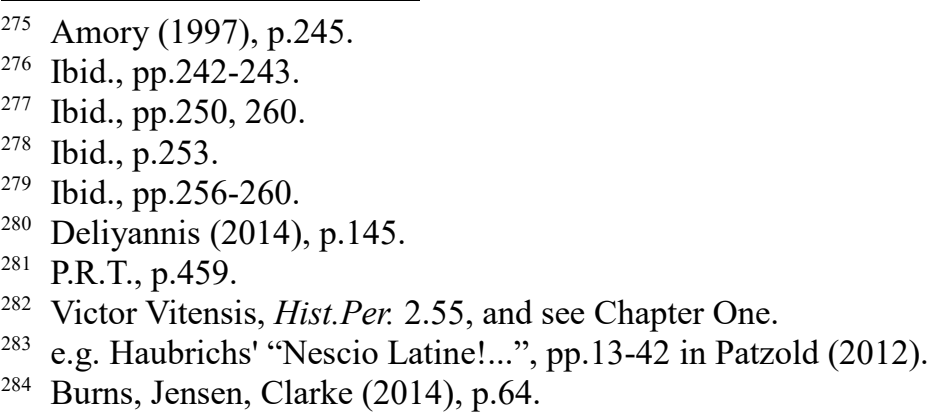


Kingdom were to convert to Arianism or lose significant legal rights and face fines, which hardly bespeaks ethnic exclusivity. ${ }^{285}$ While Victor naturally focusses on violence and coercion, the African Arian Church also engaged in peaceful outreach and charity. ${ }^{286}$ At least some of its clergy became well-respected in their communities. Despite his faith, Victorinus, Arian bishop of Ammaedara, commanded enough respect that, during a Byzantine-era renovation of the basilica he was buried in, his sarcophagus was moved to make room for relics of Saint Cyprian, but was reburied very close to the reliquary. ${ }^{287}$ But the peculiar insistence by the Vandal government on combatting Nicene belief and spreading the Arian faith (for instance, Huneric's ban on Nicene bishops performing church services, attested in Victor), ${ }^{288}$ or the violence used to pursue that end, is without parallel anywhere else in the late-antique West. Bishops suffering mass imprisonment, deportation, and exile among the Berbers ${ }^{289}$ feature prominently in the Historia Persecutionis, as does the torture and occasional execution of ordinary citizens. ${ }^{290}$ It is worth noting that, despite Victor's insistence on massacre and slaughter during the persecution, his confessors greatly outnumber his martyrs. Nevertheless, other sources also attest to persecution in the Vandal Kingdom, ${ }^{291}$ and we must therefore give it some credit.

These intensive and occasionally brutal efforts demonstrate, if nothing else, the government's determination to see Arianism established as the dominant faith in its core territories. It is difficult to reconcile the idea that the African Arian Church was an ethnic religion with this sustained campaign, both peaceful and coercive, to convert the kingdom's entire population to Arianism. This also argues against Arianism being a strategy of distinction for the Vandal people, as it was for other western ruling elites like the Goths. Spreading Arianism formed an important aspect of royal domestic policy, to the point where Amory, writing on the Ostrogoths, seems to consider it the Vandal Kingdom's most distinguishing feature.$^{292}$ But the point of a strategy of distinction is that it distinguishes one's ethnic group from others, and aggressively spreading Arianism is the opposite of the sort of boundary maintenance that keeping up such a strategy would require.

To be sure, one can certainly pick up Haubrich's impression from some Nicene sources surrounding African Arianism, especially as that is the view of Victor, the most prominent surviving writer on religious matters in the kingdom. A polemicist through-and-through, Victor militated against Arians and Vandals in the same breath, and it suited his aims to make the two groups appear as identical as possible. His was the loudest voice discussing religion in the Vandal Kingdom to survive into modern times, but this conception was not unique to him. Many Nicene writers not living under Vandal rule conflated Vandals and Arians with one another, even those who had no particular points to make about them. In De Situ Terrae Sanctae, written sometime between the death of Anastasius and Justinian's building projects in Palestine (so between 518 and 530, before the Byzantine invasion of Africa), Theodosius the Deacon gives a tour guide for pilgrims visiting the Christian holy sites in the East. ${ }^{293}$ When he gets to discussing the holy sites of Memphis in Egypt, the deacon mentions two monasteries in the city, of which "unum est religionis Vandalorum et aliud Romanorum." ${ }^{294}$ Since the characteristic religion of the Vandals was Arianism, this can only mean

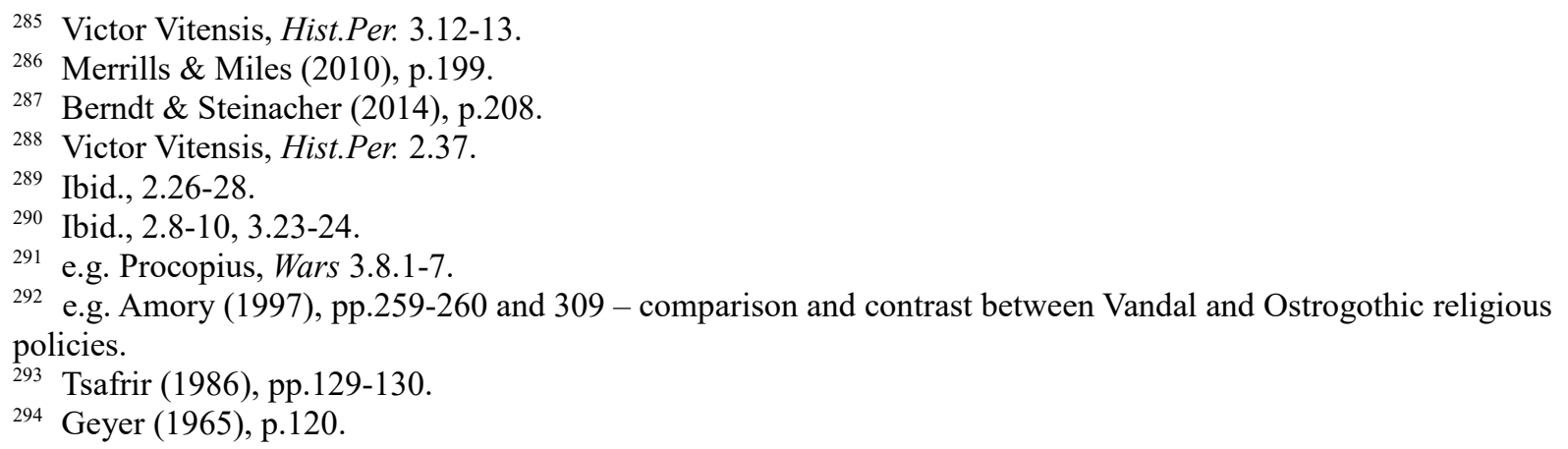


that the monastery was Arian as well. It likely had connections to the church in Africa itself, ${ }^{295}$ but the fact that Theodosius could describe an Arian monastery in this way, and expect to be understood by his Eastern Roman audience with no further explanation, points to a strong link in the Eastern mind between Arianism and the Vandals (and, equally, indicates Nicene belief as an indicium of Eastern Roman identity, since he provides no further explanation for the "Roman" monastery either). It is thus quite clear that many outsiders saw Arianism as, in our terms, an indicium for Vandality.

However, while this link between Arian belief and Vandal identity was clear in the minds of certain Roman authors, it is also clear that the Arian community in Africa saw things differently. For the ruling elites of other kingdoms, decidedly non-missionary about their faith, Arianism could serve as a strategy of distinction, a means of defining one's ethnic identity in opposition to others. But, as we have seen, the Vandals spread their Arianism as widely as possible after they established their kingdom, devoting a great deal of effort and energy to the process. While their Arianism initially served to set them apart from the vast majority of their subjects, over time, a great many RomanoAfricans converted to the Arian faith without becoming Vandals, ${ }^{296}$ and so Arianism gradually lost valence as a distinguishing indicium of the Vandal people during the Vandal century. Indeed, the African Arian Church itself never acted as if it were exclusively linked to Vandal identity. Despite the perceived close relationship between Arianism and Vandality among Eastern Roman writers, which Victor also wants us to believe in, African Arians loudly asserted their church's universality. Arian bishops insisted on the catholic nature of their creed and congregations, and were outraged by Nicene arrogation of the word "catholic" to describe specifically the Nicene church. ${ }^{297}$ This is reflected in the global outlook of the African Arian community. African Nicene polemicists remarked, as they had previously against the Donatists, that their church filled the entire world, while their opponents' churches inhabited only Africa. ${ }^{298}$ If this was ever true of the Donatists, it certainly was not of the Arians: African Arian theological writings show the authors as very concerned about issues in the global Arian church, especially their co-religionists in Nicene-ruled lands, ${ }^{299}$ and Theodosius the Deacon's "Vandal" monastery implies that Eastern Arian communities were connected in some way to their counterparts in the West. ${ }^{300}$ Arian claims of catholicity were genuine and had substance.

Moreover, the African Arian Church drew heavily on local Roman traditions, and acted in a longstanding African context and tradition. Although most concrete details elude us, we can prove there was an Arian community in Africa before the arrival of the Vandal coalition, even an assertive one. ${ }^{301}$ Arian churchmen and even individuals described as bishops show up in the writings of the famous African theologian Augustine; although some of these people are foreigners, such as Maximinus (a bishop who debated with Augustine), who arrived in Africa as an envoy for the comes Sigisvult, ${ }^{302}$ others are local and hint intriguingly at a parallel hierarchy of Arian clergy in late Roman Africa. ${ }^{303}$ Most of the time, Augustine is concerned with other (presumably larger and more important, at least in Africa) dissident sects, but while they were less important to him than, say, the Donatists or the Pelagians, Augustine's attention to the Arians implies they had at least some visible presence in the African provinces.

\footnotetext{
295 Conant (2014), p.184.

296 Berndt \& Steinacher (2014), pp.217-218.

297 Conant (2012), p.182.

298 Berndt \& Steinacher, p.253.

299 Merrills \& Miles (2010), p.199.

${ }^{300}$ Conant (2014), p.184.

301 Merrills \& Miles (2010), pp.240-243.

302 Berndt \& Steinacher (2014), p. 173.

303 Ibid., p.243.
} 
The arrival of the Vandals bolstered the Arian population in Africa, but also radically changed its composition. After Geiseric established his kingdom, the native Arian church in Africa was incorporated into that of the newcomers, and took on something of a Vandal character, as we saw in Italy. Immediately post-invasion, Arian clergy in Africa were largely outsiders, both non-African Roman and non-Roman, with native-born clerics distinctly in the minority. ${ }^{304}$ Scattered references to Vandalic in the liturgy indicate that the language was used ceremonially by the church, but Latin remained the language of church addresses to the laity (e.g. sermons), again in line with evidence from Gothic Italy. Much like the other post-Roman Arian kingdoms of the West, a pre-existing if minority Arian church hierarchy was revitalised by the arrival of Arian rulers, and influenced by their culture.

But, while its ethnic makeup may have changed drastically immediately after the Vandal invasion, the African Arian Church displayed remarkable continuity with the traditions of its earlier African forebears. Although newcomers formed the majority in the Vandal Arian Church at the kingdom's founding, its ranks had swelled by the sixth century to include many well-educated writers and theologians in an African mould, familiar with previous African theological writing and consciously writing not for a closed community but a wider, Romano-African audience. Those we know of include Fastidiosus, a former Nicene monk; Mocianus, a former teacher; and Pseudo-Origen, author of the Commentarius in Iob. ${ }^{305}$ African Arian theologians engaged with the continuum of theological discussion in pre-Vandal Africa, attacking Augustine in his weaker points and lifting African Nicene theologians' condemnations of the Donatists to deliver to their own congregations. ${ }^{306}$ The writing and sensibilities of Pseudo-Origen are remarkably similar to traditional African clergymen like Augustine and Cyprian, and his work engages with theirs. ${ }^{307}$ Arian outreach to Romano-Africans used similar tactics to those the Caecilianists used against the Donatists, holding public debates to undermine their opposition and spreading the faith through charity and good works. ${ }^{308}$

Where possible and pragmatic, the kings helped to push this process along as best they could, again in a long-standing tradition of government interference in African Christian affairs. This could take the form of coercion, such as the forceful rebaptisms and travel restrictions mentioned above, and even violence - to which Africa was no stranger, ${ }^{309}$ - but could as easily take peaceful and legal forms in long-standing Roman tradition. In 484, bishops of the Nicene and Arian confessions met in Carthage for an ecclesiastical debate under the supervision of Huneric, the second Vandal king of Africa. Debates like this were frequently staged, and indeed rigged, by late-antique rulers to advance the interests of their particular sect (this particular conference was modelled closely on the great anti-Donatist debate of 411, arranged in Carthage by the imperial government and the Caecilianist faction). ${ }^{310}$ There is a general sense from Victor that the Nicene party knew very well that the debate would be biased against them going in $^{311}$ - as with the anti-Donatist debate seventy years earlier. Thus, in terms of its religious policy, the Vandal government was acting in the best traditions of the imperial administration that preceded it.

Similarly, the Vandals made efforts to gain the support of local believers whose traditions had been

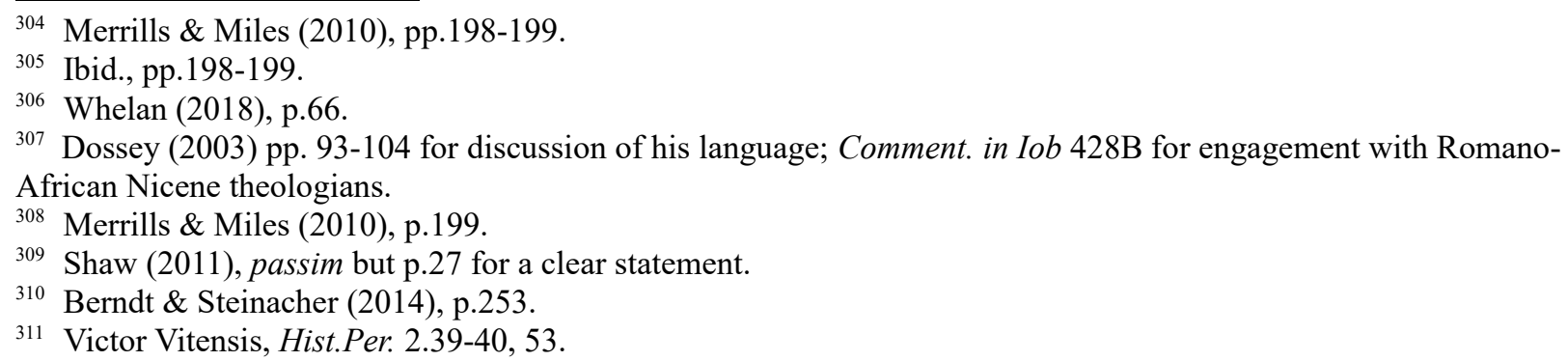


shunned and deemed heretical by the mainstream Caecilian church. Fournier perceives elements of Vandal strategy in the Arian adoption of rebaptism as a practice, both to affirm loyalty among new converts (as discussed above) and to reach out to the Donatist majority. Rebaptism was the African tradition par excellence, ${ }^{312}$ and its adoption by the Arian church grounded Vandal policy in this local tradition, leaving the door open for the rapprochement of the Arian and Donatist camps. ${ }^{313}$ But rebaptism was not the only local pre-Vandal-period belief to appear in African Arianism. Dossey notes that Pseudo-Origen is familiar with North African church controversies, and addresses them in his work. ${ }^{314}$ Moreover, some of his theological stances, such as belief in an immaculate church of saints and the irreprehensibility of bishops, suggest strong influence from Donatist thought. ${ }^{315}$ She also reads traces of Pelagianism, another doctrine popular in pre-Vandal Africa, in a poem from the Latin Anthology describing the immaculate soul of a dead infant ascending to heaven. ${ }^{316}$ Pelagians believed, in contrast to Augustine's doctrine of grace (adopted, with reservations, by the Western church), that sufficiently pure individuals could get to heaven without baptism or Christian belief, and the poem regards the child as ascending to heaven by virtue of her "puram animam:" neither baptism nor Christianity are mentioned in the poem. ${ }^{317}$ Taken together with the Arian Church's adoption (and the kingdom's promotion by force) of the practice of rebaptism, characteristic of Donatism and of North African Christianity more generally for centuries prior to the Vandal period, it appears that Vandal Arianism was influenced in some capacity by local dissident beliefs. These beliefs are not known among other Arians, ${ }^{318}$ and they indicate that the African Arian Church was open to incorporating aspects of other religious movements popular in Africa.

Whether this was a tactical move on the part of the Vandal Arian Church to more easily incorporate local dissidents against the imperially-approved form of Christianity, or simply a result of its priests, raised in an African milieu, giving expression to doctrines they were already familiar with in a church that had not ruled against them (unlike the imperial church), cannot be determined with certainty. In either case, though, the Arian Church was open to theological influences from African sects, which would have facilitated those dissidents' entry into its own ranks. Indeed, the Arians patronised and brought under their control the Cypriana, the feast of the third-century bishop (now saint) Cyprian of Carthage, whose cult was important in Africa and the wider Christian world even into Islamic times, ${ }^{319}$ and whom we last saw defending the traditions of Africa (specifically rebaptism) against the bishop of Rome and the wider church. Cyprian was a deeply attractive figure to the Donatists, ${ }^{320}$ and Arian co-option of his festival would have signalled to local Christians, many of whom were Donatists, that the new church and regime valued their traditions.

These official royal policies were at least somewhat successful. We hear of many Romano-Africans converting to Arianism, especially among the secular elite, ${ }^{321}$ but also among clergymen and theological writers. ${ }^{322}$ Whether they were converting from genuine conviction, coercion, or a pragmatic desire for advancement in an Arian-dominated state, they indicate that neither Vandals nor elite Romano-Africans perceived religious profession as a particular line in the sand between the two peoples. Likewise, we hear of Vandals joining the Nicene church. ${ }^{323}$ The general

\footnotetext{
12 Brakke, Deliyannis, Watts (2012), p.252.

313 Ibid., p.244-245.

314 Dossey (2013), pp.87-89.

315 Ibid., pp.112-113.

316 AL $R 92$.

317 Dossey (2013), p.113.

318 Brakke, Deliyannis, Watts (2012), p.248.

319 Merrills (2004), pp.305-306.

320 Tilley (1996), p.1.

321 Berndt \& Steinacher (2014), pp.217-218.

322 Dossey (2003), p.111.

323 Ibid., p.247.
} 
population's attitudes are harder to determine, but we have an Arian tract exhorting Arian believers to avoid Nicene churches, ${ }^{324}$ and palpable anxieties from several Nicene authors about their congregations attending Arian services. ${ }^{325}$ The existence of these warnings and anxieties implies that such behaviour was not uncommon, and it is largely impossible, archaeologically speaking, to distinguish between Nicene and Arian churches in Africa and elsewhere, ${ }^{326}$ which must have facilitated intermingling of congregations, especially in smaller communities with only one or a few basilicas. ${ }^{327}$ Merrills and Miles even concluded that "doctrinal ambivalence and the religious flexibility of African Christians was a far greater threat to the exiled Nicene Church than was Arian proselytising." ${ }^{328}$ It is unlikely, then, that a largely Romano-African, Berber, and possibly Punic population saw Arianism as peculiarly Vandal, if they were able to move between churches serving different congregations with such ease. Quodvultdeus warns his flock against being tempted by the Arians and their offer of worldly goods, and frets about them seducing many Nicenes through various wicked ways, which is also a strong indicator that many regular people were coming over to the Arian faith. ${ }^{329}$ To associate Arianism in Africa with the Vandals was to ignore the realities on the ground. Eastern Roman writers did it, but most African authors did not, and it has been plausibly suggested that Victor primarily intended the Historia Persecutionis to be read overseas, as a plea for outside intervention, ${ }^{330}$ with perhaps a certain amount of prejudice-stirring to harden Nicenes at home and abroad against conversion or co-existence. ${ }^{331}$

It is clear, then, that neither the Vandal government nor the Arian Church (and for that matter, most Nicenes) treated Arianism in Africa as exclusive to the Vandal people. While Arianism was an important part of state ideology, it was not seen as an ethnic religion by either Arians or (most) Nicenes by the time of Justinian's invasion. There were Arians in Africa prior to the Vandals' arrival (and they were a significant minority, not a scattered few), ${ }^{332}$ the Arians referred to themselves as catholic, and few Nicene polemicists in Africa itself equate Arianism with Vandality. ${ }^{333}$ Aside from Victor, most Nicene authors did not even mention Vandals or barbarians when discussing Arianism, and were content to leave ethnicity and confession as separate. Arianism's development in Africa, while incorporating aspects of Vandal culture (such as the Vandalic passages in the liturgy discussed in Chapter One), was also heavily shaped by Roman precedents such as the stage-debate of 484 and by local African-Christian influences such as the practice of rebaptism, and Romano-Africans were encouraged, and occasionally forced, to become Arians. This tells us that Arianism in Vandal Africa was not an ethnic religion, as its out-group was not Romano-Africans (after all, the Arian Church was home to many Romano-Africans and shaped just as much by its Roman and African context as by any aspect of Vandal culture) but Nicenes, whose church had a distinct second-class status even when not violently persecuted. ${ }^{334}$ All citizens of the kingdom were allowed and expected to participate in Arianism, regardless of their ethnic background.

324 Ibid., pp.109-110.

325 Merrills \& Miles (2010), p.192.

326 Berndt \& Steinacher (2014), p.215-217.

327 Ibid., p.218.

328 Merrills \& Miles (2010), p.192.

329 Brakke, Deliyannis, Watts (2012), p.247.

330 Merrills \& Miles, pp.186-187.

331 Berndt \& Steinacher (2014), pp.268 n.50

332 Merrills \& Miles (2010), pp.240-243.

333 Berndt \& Steinacher (2010), pp.247-248. Cf. Amory (1997), p.260 n.100, but Amory's only source for the claim is Victor himself. As the focus of his work is on Ostrogoths, not Vandals, I suspect Amory is relying solely on Victor, without looking at any other African churchmen.

334 The status of Nicenes fluctuated throughout the kingdom's lifespan. At times, for instance, they were barred from holding public office (Hist.Per. 1.43) and faced edicts banning them from consecrating new bishops to replace those that had died (Merrills \& Miles (2010), p.196). 
Unlike the other western rulers, the Vandal kings were clearly not concerned with maintaining Arianism as a distinguishing strategy of Vandal identity: the state and church deliberately invited, or tried to force, Romano-Africans to participate in Arianism as a means of promoting loyalty to the Vandal state. This would have had a knock-on effect of encouraging Romans to abandon a key indicium of their own ethnicity, and while Arianism formed a strategy of distinction for the Vandals in pre-African times, the state's promotion of Arianism over the Vandal century would have rendered this distinction meaningless. What we see in Vandal religious policy is thus an attempt at construction of common ground based on religion, rather than systematic othering of an out-group. It thus makes more sense to think of Arianism not as a strategy of distinction, but an identitybuilding strategy through which a sense of common in-group status could be created and affirmed among both peoples of the kingdom: in other words, as a strategy of identification. The Vandal government's efforts to make Arianism universal among its subjects represent a deliberate attempt to secure the loyalty of its peoples on the grounds of state-approved religion: given the close relationship between ethnic identity and religion in this time, this would have (perhaps unintentionally) promoted a common identity between the two peoples, bringing them closer to an eventual fusion.

These different strategies, distinction and identification, are of course two sides of the same coin, as creating an in-group necessarily requires differentiating them from outsiders. Political actors can reframe strategies and conversations concerning ethnicity to suit their ends, ${ }^{335}$ and whether or not the Vandal monarchs intended it, that is precisely what they were doing with their missionary activity. Strategies of distinction require a process of boundary maintenance to maintain, but the regime's missionary activity represents an opposite process, the erosion of boundaries. This turned religion not into a strategy of distinction but an exercise in common identity construction, a bridge between the peoples rather than a wall. Certain Romans raised their voices angrily in response to this - Victor, especially, heaped scorn on those who found themselves drifting closer to the barbarians ${ }^{336}$ - but the anxieties of other African Nicene writers about their congregations attending Arian churches and services ${ }^{337}$ tell us that the average Roman had a greater sense of flexibility and openness about questions of doctrine than stalwarts like Victor or Quodvultdeus. We have already seen that ordinary Romans were quite adaptable, in religious terms, when it came to which church to attend. So too were the provincial elites. Most of the voices we hear in protest of Arianism come from clergy and theologians: the local Romano-African aristocracy, after the initial shock of the invasion, accommodated themselves quite well with the new regime, including its new religion, and in general the partnership between Vandals and Romano-African elites was fruitful. ${ }^{338}$ As time went on, we hear of a great many of these nobles converting to Arianism. ${ }^{339}$ In doing so, they were going against a conviction that Eastern Romans and Nicene church writers in Africa alike held dear: that holding to the Nicene faith was a major part of being a Roman. The idea that Arianism constituted an exclusive ethnic religion for the Vandals, or even that Arianism marked Vandal identity and Nicene belief marked Roman identity, was thus demolished from both sides in Vandal Africa.

While personal piety was likely important to them, we know that the Vandal kings thought strategically about religion. Jordanes and Hydatius attest to the kings' politically-motivated religious waverings while in Spain, and, once in Africa, they used their ability to threaten Nicenes under their rule to some effect when trying to wrangle concessions out of the emperors. Likewise, their promotion of the Arian Church helped to create a support base for them in Africa, which supported steadfastly Arian kings in times of crisis and from which they could recruit loyal subjects to serve in

\footnotetext{
335 Surdu (2016), pp.52-53.

336 Victor Vitensis, Hist.Per. 3.62-65.

337 Merrills \& Miles (2010), p.192.

338 Miles (2005), p.313.

339 Berndt \& Steinacher (2014), pp.217-218.
} 
their administration. Religion was a key marker of loyalty in the Vandal state, just as it was in Rome and Persia, and the Vandals used it as a yardstick with which to measure the loyalty of their subjects, both individuals in the court and the wider population. Their devotion to converting the whole of their realm to Arianism, the largest and most sustained policy effort undertaken by the Vandal government that we know of, can in this light be explained as an attempt to unite their realm based on grounds of religion. They used the same laws that the emperors did in enforcing doctrinal unity in their own realm, and for much the same purposes: to impress upon their subjects a church that was controllable and answerable to them and to ensure the loyalty of their subjects in a climate where loyalty was intimately linked to membership in the approved religion, and religious heterodoxy a mark of deep suspicion to rulers across the Mediterranean.

The Vandal kings clearly had a pressing need to ensure the loyalty of their subjects, perhaps more than any other Western ruling elite. Vandal Africa was near-constantly under high external threat, and not only from Berbers: the Eastern Empire attempted reconquest on several occasions during the fifth and sixth centuries before Justinian's final successful invasion. ${ }^{340}$ This notion of reconquest was predicated in part on the idea that the Vandals' Nicene subjects were inherently disloyal (which is why Belisarius severely punished his troops for looting: he saw it as turning a potentiallywelcoming local population over to the Vandals' side), ${ }^{341}$ and the kings thus pursued Arianisation as a way to unify their subjects behind them. We have seen that violence, forced conversion, and accusations of disloyalty peaked elsewhere in times of extreme threat or crisis, and the Vandal Kingdom was near-constantly under external threat. This may go a long way towards explaining why the kings were so unusually enthusiastic about spreading the Arian faith. Given the constant external threats the kingdom faced, national unity was a life-or-death matter for its ruling elite, and mass conversion to Arianism would not only have helped shore up their reign but provided a barrier against imperial reconquest. ${ }^{342}$

This aim of national unity reflected itself in the character of the African Arian Church. Although Haubrichs asserts it was an ethnic religion specific to the Vandals, examination of African Arianism's nature and composition reveals it to have been anything but. The Arian Church was never exclusive to Vandals: in fact, most of its priests in the later period of the Vandal Kingdom were Romano-African. Its outreach was directed towards everyone, and the frettings of Nicene authors about Arians corrupting the souls of the faithful indicate it had at least some success in this. While it had elements within its rituals and practices that we might call ethnic, as many of these elements came from local African culture as from Vandal: the use of Vandalic in the liturgy exists alongside the ritual of rebaptism, characteristic of African Christianity in general and a particular hallmark of the popular African religious movement of Donatism. If, then, the African Arian Church gestures towards anything to do with ethnic identity, it is the same fusion of cultural influences, with Roman and African influences predominating, that we saw in the kingdom's cultural makeup in Chapter One. Far from a stumbling block on the road towards Judith George's advanced state of fusion, it was a product of it.

But not merely a product. Religion, as we have seen, was a principal indicium of ethnic identity in late antiquity. Many different peoples used particular religious affiliations as strategies of distinction to help define themselves and their communities against others: the approved doctrines of the imperial church, such as the Nicene or Chalcedonian creeds, became heavily bound up in Roman identity, while other peoples such as Jews or Egyptians used adherence to a different faith or creed to distinguish themselves from the Roman mainstream. Arianism performed this function for the

\footnotetext{
340 Merrills \& Miles (2010), pp.111-122.

341 Procopius, Wars 3.16.1-8.

${ }^{342}$ Conant (2012), p. 184.
} 
western elites, including the Vandals. But the church's strong outreach towards non-Vandals brought many Romano-Africans into the fold, with profound implications for how those Romans viewed their ethnic identity, and its openness to their ideas and practices would have shaped the Vandals' perception of Arianism in turn. The strongest evidence for this is the wholesale adoption by the Vandal government of the practice of rebaptism (so much so that they even gave out passports based on whether one had been rebaptised), unknown among other Arians but which came to feature prominently in Nicene polemics against the African Arians. Rebaptism became an integral feature of the Arian Church in Africa, as evinced by the state's constant use and endorsement of it; thus, Arianism being a major indicium of Vandal identity, this quintessentially African doctrine becoming part of the Arian Church's standard practice would have placed elements of local African Christianity at the very heart of what it meant to be a Vandal. At the same time, Vandal elements such as the Vandalic liturgy persisted even after the initial invasion period, when the church was mostly comprised of non-Vandals, showing that local Christians had accepted aspects of Vandal culture in their religious practice as well. African Arianism was not just a product of the climate of ethnic fusion in Vandal Africa, but a vehicle which furthered that fusion.

We thus come full circle to the strategy of identification. The kings supported Arian outreach as a way to politically unify their subjects and shore up their reign, recognising that religious identity was inherently bound up with loyalty and political affiliation. But religious affiliation was also tightly bound to ethnic identity, and by altering their subjects' religious beliefs and practices (be it pushing Arianism on the Romano-Africans or adopting African beliefs into a church that defined Vandal identity), the government was also - intentionally or otherwise - fundamentally changing their subjects' conceptions of themselves. ${ }^{343}$ Arianism created a bridge between the peoples, drawing them together as an in-group against outsiders and creating space for cultural cross-pollination and mutual identity construction. Although this process was, in the end, cut short, we can deduce from the available evidence that the Africans were considerably reconciled with the Vandals by the time of the invasion on religious as well as cultural grounds. ${ }^{344}$ The diminishing violence of the Arian persecution towards the end of the kingdom's lifespan is symptomatic of the increasing interweaving of the Vandal and Romano-African communities. ${ }^{345}$ Given the degree to which it combined elements of Vandal and African culture within itself, it is safe to conclude that the Arian Church in Africa was shaped by that reconciliation; given the degree to which religion shaped conceptions of ethnic identity in late antiquity, it is also safe to conclude that the church, in turn, helped to shape that ongoing fusion.

\footnotetext{
43 Ibid., p.184.

344 Ibid., p.186.

345 Ibid., p. 195.
} 


\section{Chapter Three \\ Carthago excellens Libycas per oras: The making of a new African identity}

Ethnicity is largely framed by the dominant group in society, ${ }^{346}$ and we saw in the last chapter that the western kingdoms dabbled in cultural policy for the sake of promoting national unity. Historical writers, for those kingdoms that produced a great work of history, played an important role as mediums in the negotiation of cultural unity and distinction between the elites and their subjects, and their works were central to the construction and negotiation of identity in the post-Roman west. ${ }^{347}$ Isidore of Seville, writing in the Visigothic Spanish Kingdom, promoted a Gothic national identity inclusive of Hispano-Romans but exclusive of Byzantines, encouraging the Romans of Spain to see the Visigoths as fellow Spaniards and their benefactors (and, conversely, the Byzantines in southern Spain as alien, heretical invaders). ${ }^{348}$ Meanwhile, Gregory of Tours elided ethnic differences between the Frankish Kingdom's inhabitants in the name of promoting cultural unity on religious grounds. Vandal Africa, unfortunately, does not have an easily-available Isidore or Gregory, but we can detect outlines of promotion of national unity and identity in surviving elements of official (or officially-sponsored) Vandal material.

It is possible to build up a picture from this material of how the Vandals wanted themselves and their kingdom to be seen by their subjects. Vandal state propaganda aimed to legitimise their place as inhabitants and rightful rulers of Africa, which they did by linking themselves to Carthage, and by framing their monarchy in impeccably Roman style, drawing on imperial precedents and exploiting their marriage ties to the Theodosian imperial house (via Huneric's marriage to Valentinian III's daughter Eudocia). Simultaneously, they asserted the prominence and prosperity of the grand capital of Africa, Carthage, under their rule, directing their subjects' attentions away from the old imperial centres and towards their own metropolis. They also promoted a shared culture, based on Roman forms but with a peculiarly African focus (e.g. resuscitating pre-Roman Punic symbols in certain contexts), and even African pride and identity, shareable between RomanoAfrican and Vandal, which some of their subjects appear to have embraced. Examples of this ideological material can be found on the kingdom's coinage, in its poetry, and in the Carthagecentric calendar adopted by the regime, all of which this chapter will discuss.

Africa's written record being sparse, it can be difficult to perceive ways in which people thought of themselves and each other. This can make changes in identity difficult to detect. But the few private documents that we have suggest that Vandals and Romano-Africans were finding common cultural ground. The correspondence between Parthemius, a presbyter in Vandal Africa, and Sigisteus, a Vandal comes, offers us a rare and tantalising glimpse into the inner lives of Vandal-era Africans. These letters are notable for their obvious flattery (at one point Sigisteus equates Parthemius' spiritual stature with the pope's) ${ }^{349}$ but also for what they can tell us about cultural relations in Vandal Africa. In his letter, Parthemius compliments the Vandal as follows:

"Learned Greece has not produced such a man, nor has great Larissa given birth to such an Achilles, but valiant and fertile Africa bore such a fruit to us: a man who, shining of course with bright light, was then raised from our gentle breast to the stars." 350

\footnotetext{
346 Barth (2006), p.31.

347 P.R.T., pp.126-127.

348 The heresy in this case is the Three Chapters Controversy. P.R.T., pp.125-168 passim.

349 Whelan (2018), p.221.

350 Parthemius, Rescriptem ad Sigisteum 8-12.
} 
In a letter from a Romano-African to a Vandal, this is an intriguing statement. There is no hint of alterity here. In fact, the peculiarly possessive language ("nostro de pectore") implies the opposite: Parthemius includes Sigisteus as part of his own group. Sigisteus is raised to the stars not as a Vandal or barbarian, but a native son of Africa. ${ }^{351}$ It also displays a strong sense of pride in Africa itself, with Greece and Larissa put in the shade by Sigisteus' African-born learning and prowess. This African pride would outlast the Vandal Kingdom itself: Fulgentius the Mythographer tells a tale about Calliope, the muse of epic poetry, wandering through all the cultural centres of the Mediterranean before finally deciding to make her home in Africa, which Conant takes as a sign that he regarded his home as "the reigning heir of the classical literary tradition." 352 Late-antique Africa was determined not to be second-best to anyone.

Parthemius also demonstrates that classical tropes like Achilles' martial prowess remained current in Vandal Africa, and not just for flattering Sigisteus: Hoamer, a prince arrested and mutilated by Gelimer during his coup, was also known as "the Vandal Achilles" for victories against the Berbers. ${ }^{353}$ There is a hint of Vergil in line 7's "te absentem gratulor absens," 354 reminiscent of line 4.83 of the Aeneid. Classical culture was feted in the Vandal court: Thrasamund and Hilderic were avid patrons in the Carthaginian literary scene, but even works from early in the kingdom's lifespan, such as Martianus Capella's Marriage of Philology and Mercury, display a taste for traditional religion and classical learning. ${ }^{355}$ Indeed, the poets of Vandal-era Africa stuck rigidly to the secular and classical. Verses celebrate Fridamal's garden, complete with statue of Diana, ${ }^{356}$ or talk about a tamed boar passing from wild Mars' domain to gentle Venus, ${ }^{357}$ but even in poetry memorialising the death of loved ones (such as Luxorius' lament for Hoageis' daughter), explicit Christian reference is absent. ${ }^{358}$

This tradition of celebrating the secular and ignoring the religious among Romano-African provincial elites was inherited from late Roman times, in which Donatist-Caecilianist and Christianpolytheist tensions were high, and aristocrats retreated into the secular as a safe cultural ground. ${ }^{359}$ The Vandals inherited the tradition and continued it, building a flourishing cultural milieu that all their subjects could partake of. Miles argues that "the extraordinary renaissance of Latin literature in fifth- and sixth-century Africa appears to have been driven by the need for the Vandal monarchs and Romano-African elite to create a political modus vivendi." ${ }^{360}$ The kings did not use literature alone in this way: art, architecture, and even the calendar were employed to create images of harmony, prosperity, and cultural unity. Romano-African high culture was the prestige culture of Vandal Africa, and the government exploited it to promote its own ends.

A poetic panegyric by Florentinus from early in the reign of Thrasamund (thus sometime after 496), praising the king on his completion of a bath complex at Alianae, provides the clearest example of this usage of culture. ${ }^{361}$ Felix, another esteemed African court poet, also issued a series of poems in celebration of this project at around the same time, so it is safe to say the king was quite interested

351 Merrills \& Miles (2010), p.99.

352 Conant (2012), pp.55-56.

353 Merrills \& Miles (2010), p.99.

354 Parthemius, Rescriptem ad Sigisteum 7.

355 Merrills \& Miles (2010), p.226.

356 AL $R 304$.

357 AL $R 292$.

358 AL $R 345$.

359 Miles (2005), p.308.

${ }^{360}$ Merrills \& Miles (2010), p.226.

361 Apparently a suburb of Carthage, but its location is uncertain, as is whether Thrasamund's baths were a new structure or the renovation of an existing one. Ibid., pp.223-224. 
in advertising it. ${ }^{362}$ But while Felix focusses more on the actual bathing complex, Florentinus only lightly touches on it. Florentinus' poem mostly eulogises two subjects: the glory of Thrasamund, and the glory of Carthage. Its effusive verses pile praise on both. The first half flatters the king in every imaginable quality:
Imperiale decus Thrasamundi gloria mundi regnantis Libyae. Toto sic clarior orbe
Sol radiante micans cunctis super enitet astris.
In quo concordant pietas prudentia mores
virtus forma decus animus sensusque uirilis
invigilans animo sollers super omnia sensus.
"The imperial splendour of Thrasamund, ruler of Libya, is the world's renown, just as the glittering sun,
brighter than the entire shining universe, stands forth above all other stars.
In him converge reverence, foresight, good character,
bravery, handsome appearance, distinction, spirit, vigorous education,
and a very adroit intelligence that watches over everything." ${ }^{363}$

The second half is a hymn of praise to Carthage itself, beginning:
Nam Carthago suam retinet per culmina laudem
Carthago in regem. victrix Carthago triumphat
Carthago Asdingis genetrix. Carthago coruscat
Carthago excellens Libycas Carthago per oras.
"For Carthage, Carthage, retains her repute by her summits
and by her king. Carthage the victress triumphs,
Carthage mother-city to the Hasdings. Carthage glitters,
Carthage, Carthage, exulted throughout the Libyan lands." ${ }^{364}$

Following from this, we read that Carthage is "learned... embellished with teachers... rich in peoples... radiant..." and so on, ending with "Carthage flourishes, ruling in Thrasamund's name." 365 The repetition of the poem is called "almost deranged" by Miles, ${ }^{366}$ not without reason, but that insistent repetition of Carthage's glorious attributes hammers home to the reader how important the city was in the eyes of its rulers. This poem is perhaps the closest thing we have to a manifesto of the Vandal kings' ideological aspirations, ${ }^{367}$ and it shows that they placed Carthage at the heart of their rule in terms of legitimacy and culture. Carthage, as Florentinus points out, is the civilisational centre of Africa; indeed, he rather implies that it is the centre of the world, for he tells Thrasamund that "the Creator... has granted and allowed you alone to possess all these things [i.e. the fruits of all lands]" 368 in his kingdom. This cynosure of civilisation is maintained by the Hasding kings, Thrasamund in particular, whose qualities are renowned across the world. ${ }^{369}$ The symbiotic nature of the relationship between Carthage and the Hasdings is explicit. Carthage is mother-city of the Hasdings, but it is by a Hasding king that the city is able to retain its repute. Its flourishing is directly linked to their august administration: Florentinus says as much when he proclaims that "So

\footnotetext{
${ }^{362}$ Ibid., p.224.

${ }^{363} A L R 376,2-7$. Translated by Clover (1986), with adjustments by me.

364 Ibid., 28-31.

365 Ibid., 32-36.

${ }^{366}$ Merrills \& Miles (2010), p.223.

367 Clover (1986), p.8.

368 AL $R$ 376, 17-18.

369 Ibid., 2-3.
} 
that [Carthage's] empire might remain fortunate throughout the ages, we desire to observe annual festivals for Our Master for many years...," 370 clearly linking the fortunes of the two together. Carthage, then, is the symbol and legitimating badge of the Vandal regime: its prosperity demonstrates their right to rule. ${ }^{371}$

Florentinus' poem demonstrates both the centrality of Carthage to Vandal state ideology and the links they tried to promote between themselves and the metropolis. We can see in it the central position of Carthage at the heart of the Vandal realm, politically and culturally, and its claims to be a capital on the world stage, a viable competitor with the established cultural centres of Rome or Constantinople. Civic pride comes out further in other poems of the Latin Anthology: Luxorius' poems are dedicated as much to the public spaces and monuments of Carthage as to the people living there. ${ }^{372} \mathrm{He}$ celebrates the forum as the place where his youthful poetry was written, ${ }^{373}$ the statues of Fama and Victoria outside the circus stables, ${ }^{374}$ and other public spaces around the city. Other poems celebrate the delights of the city, such as charioteering, gladiatorial matches, and other pleasures. ${ }^{375}$ Where Florentinus' focus is on the larger picture, Luxorius offers us a smaller-scale viewing of the city's splendours and pastimes: between them, the image one gets is of a cultured municipal elite with a great deal of pride in their metropolis.

This fierce local pride is also reflected in the letters between Parthemius and Sigisteus: the presbyter's claims that Greece never produced such a man of learning or martial prowess as Africa has in Sigisteus display an assertive sense of African pride, casting Africans as in no way inferior to their counterparts overseas. Just as there is no trace of alterity in Parthemius, so too is there none in Florentinus. Carthage is mother-city of the Hasdings, and Africa bore the glorious Sigisteus: both are acknowledged as sons of Africa by Parthemius and Florentinus. That these particular Africans, Sigisteus the paragon of war and learning and Thrasamund the world-famous ruler, are Vandals is of little consequence to either author. They are people produced by Africa who enrich Africa in turn, and it is through them that Carthage and Africa can count themselves equal in stature to anywhere else in the world. The Maeotian "homeland" which Procopius attributes to the Vandals ${ }^{376}$ is nowhere in sight: the (approved) discourse in Vandal Africa, public and private, cast the ruling elite as rooted firmly in African soil.

The impression created by these written documents is reinforced by the remaining physical evidence, in forms which circulated far out into the provinces and into the hands of individuals likely with little connection to the Carthaginian literary scene. While late-antique Africa remains under-excavated, we have several items traceable back to the Vandal Kingdom, including a formidable array of coins. The mint at Carthage operated throughout the Vandal period, both recycling old imperial motifs and displaying some surprising innovations. Coinage, alongside poetry and official documents, formed an important broadcast network for state policy and ideology to the African general public. ${ }^{377}$ What messages, then, should we read into the Vandal kings' coinage?

The post-Roman period in the western Mediterranean saw a revival of ancient symbols on coinage that had fallen into disuse during the Imperial period. Under Ostrogothic rule, the Roman mint

\footnotetext{
370 Ibid., 37-39.

371 Whelan (2018), p.8.

372 Miles (2005), pp.309-310.

373 AL R 287.

374 AL $R$ 312, 313.

375 Miles (2005), p.310.

376 Procopius, Wars 3.3.1.

377 Clover (1986), p.8.
} 
produced a series of coins depicting the twins Romulus and Remus suckling the wolf, a motif that had gone into abeyance for quite some time. ${ }^{378}$ Likewise, under the Vandals, the mint of Carthage produced coins that used, alongside the Lady Carthage iconography that had become popular during the Tetrarchy, motifs that had not been used (or had been used only sporadically) since the Punic era.

Lady Carthage (fig.4) is herself a significant figure: the personified figure of Carthage, her presence on Vandal coinage is a demonstration of the city's prominence in the national psyche of Vandal Africa (or at least in the ideology of the ruling administration). ${ }^{379}$ The floral wreath in her hair and the sheaves of grain in her hands, symbols of the wealth of Africa and Carthage, find an echo in the lavish descriptions of Carthage's wealth and prosperity in Florentinus' panegyric to Thrasamund. The legend FELIX KARTHAGO that many of them bear is also an old Roman motto of the city, revived by the Vandals and printed on their coins, once again placing Carthage at the centre of their ideological message. ${ }^{380}$ Other coins bear the similar statement CARTHAGINE P $[E R] P[E T U A],{ }^{381}$ broadcasting a similar message.

Equally interesting are the older motifs employed by the Vandal-era mint of Carthage. Chief among these resuscitated symbols is the horse's head (fig.5), a device not found on Roman-era coins from the city, but prominent on Punic coinage from the heyday of the Carthaginian Empire. ${ }^{382}$ The use of devices with a non-Roman, African past is suggestive. Clover links the use of horse-heads on these coins to the contraction of imperial authority into the east and the consequent increased stature of large western cities like Carthage, ${ }^{383}$ and it is no surprise that the Vandals would take advantage of this trend, as they had a vested interest in promoting local African identity and heritage. We have seen Luxorius frame his poetic milieu as "punica," while Parthemius flattered Sigisteus in proudly African terms, and we know that local literati avoided declarations of Roman identity. These statements and avoidances gesture towards a sense of localism and local pride in Vandal Africa, borne out elsewhere in the post-Roman west, which seems to have persisted even after the Byzantine invasion. Fulgentius the Mythographer, publishing in early Byzantine Africa, still referred to himself as Libyan, and still regarded Africa as pre-eminent seat of classical culture. The mint's revival of symbols celebrating the city's foundation and history also represents the Vandal government encouraging this trend, ${ }^{384}$ just as they took steps elsewhere to redirect their subjects' attention towards Carthage, Africa, and local identity.

But it is not merely in iconography that Vandal-era coins emphasise the primacy and importance of Carthage. Quietly but proudly placed alongside Lady Carthage on some of these coins is the legend "ANNO $[N] K$." This stands for anno Kart $[h]$ aginis, "the year of Carthage," a form found in numerous other instances in Vandal Africa, such as inscriptions from Hippo Regius and Madauros ${ }^{385}$ and ostraka from Bir Trouch. This Carthage-year dating system began under Geiseric, starting with the fall of Carthage to the Vandals in 439, and continued under his successors. Exactly how it worked is uncertain. Examining the available evidence, Clover concludes that the likeliest scenario was that it was a form of regnal dating, the number resetting with each monarch. ${ }^{386}$ The Bir Trouch ostraka bear this out: they contain a full form anno $[N]$ Karthaginis domini nostri regis $[X]$ ("the

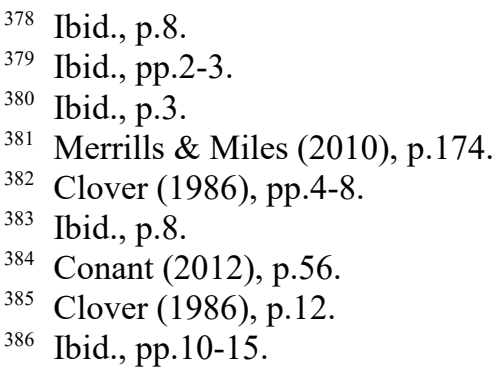


Carthaginian year $[\mathrm{N}]$ of our lord, King $[\mathrm{X}]$ "), and it is now generally accepted by numismatists that the simple anno $[N] K$ is an abbreviation of this longer form. ${ }^{387}$ Regnal dating was common in late antiquity, but the insertion of Carthage into the formula is an unusual step, linking together Vandal royal power and the stature of Carthage. ${ }^{388}$ Placing the capital on their coins and in their calendar like this is a powerful ideological statement, demonstrating the importance of the city to the Vandal regime, an importance they clearly wanted to emphasise to their subjects.

Rewriting the calendar for the purposes of promoting their ideological vision was an ambitious and novel step, but the kings went further, recycling existing Roman infrastructure and offices in ways that reinforced their rule and promoted loyalty. ${ }^{389}$ In Ammaedara, we find the epitaphs of two generations of local Romano-African aristocrats, the Astii. Three of them are buried in the basilica, Vindicianus, Mustelus, and Dinamius, each one also identified with their office: Vindicianus and Mustelus are listed as flamines perpetui, while Dinamius is a sacerdotalis provinciae Africae. The date on Mustelus' inscription, anno IIII d(omi)n(i) regis Idirix, corresponds to 526, close to the end of the Vandal Kingdom's lifespan. ${ }^{390}$

The titles flamen perpetuus and sacerdotalis come from emperor worship and traditional religious practices, and their appearance in late Vandal Africa, thoroughly Christianised and no longer under imperial rule, has caused no small amount of scholarly speculation. They show up elsewhere in the kingdom: one Flavius Geminius Catullinus, flamen perpetuus, appears on the Tablettes Albertini, a cache of Vandal-era legal documents recovered from western Byzacena. ${ }^{391}$ This implies that the old priestly offices remained current among municipal elites. Their pagan origins were understood by the aristocrats who bore them, ${ }^{392}$ but with emperor-worship banned in the fourth century, their duties had long since been secularised. ${ }^{393}$ Clover has argued that the flamines practised a form of authorised emperor-veneration, acknowledging the Vandals' subordinate foederati status to the emperors, but given how touchy the Vandal kings could be about loyalty, as we saw last chapter, it is highly unlikely that they would allow this kind of ritual loyalty to a foreign ruler to continue. In any case, the Vandals had not been foederati for decades by the time of these inscriptions. ${ }^{394}$ Chastignol and Duval's explanation, that the Vandal kings deflected this civic veneration of the emperors onto themselves, ${ }^{395}$ remains the likeliest position. ${ }^{396}$

This redirection has profound implications: public rituals affirming the devotion of aristocrats to their ruler, thoroughly scrubbed of any religious content, fit well in the secular space of cooperation envisaged by Miles, establishing a ritual-based confirmation of royal authority. ${ }^{397}$ It may also be evidence for the survival of the provincial council as an institution as late as the sixth century, allowing aristocrats to communicate their concerns to the Vandal kings. ${ }^{398}$ Just as importantly, it focussed the attentions of the provincial aristocracy away from Rome and Constantinople and

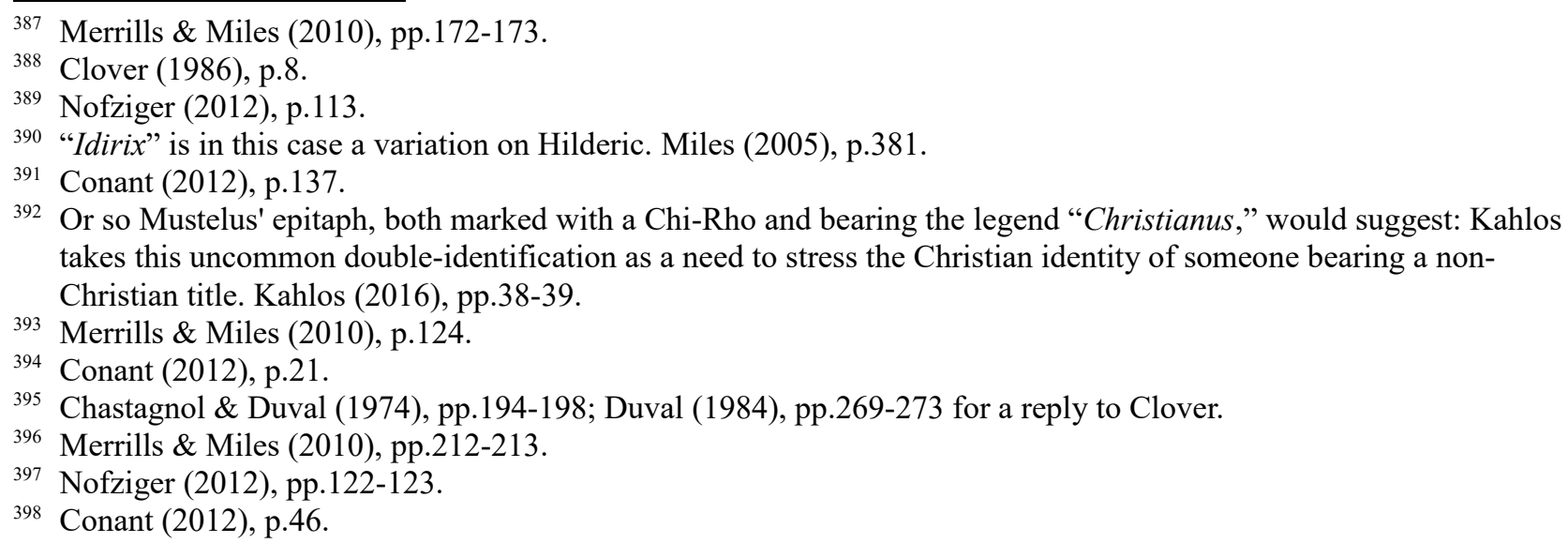


towards Carthage and their kings, creating links between ruler and elite. ${ }^{399}$ Creating a patriarchate in Carthage would likely have had a similar effect, drawing the religious devotion of the kingdom's citizens away from distant imperial cities and centralising it on the Vandals' capital, in the form of a figure controllable by the Vandal kings. ${ }^{400}$ As mentioned last chapter, theological independence from the other centres and the ability to create a national church centred on (and controllable by) themselves was a major element of the Vandals' and other western elites' strategy concerning Arianism, and establishing a patriarchate of Carthage would have helped the Vandals achieve both goals.

On occasion, the kings saw fit to evoke the memory of their pre-African past, but their usage of this legacy was narrow and only appears to us in particular contexts. The best-known Vandal title, rex Vandalorum et Alanorum, certainly gives the impression that the ethnic groups united under the Vandal banner in Spain still existed in the Vandal Kingdom even at its end. Our sources for this particular title are both Victor and Procopius: Huneric signs his decrees of persecution in Victor as "Hunirix rex Vandalorum et Alanorum," 401 and the Vandal prince Tzazon addresses Gelimer with the same title in Procopius. ${ }^{402}$ The continued usage of this title, even at the time of the invasion, has been taken as a sign that the Vandals still had a strong ethnic-Vandal consciousness, ${ }^{403}$ and even as proof for the continued existence of an Alan ethnic minority in the Vandal Kingdom in Gelimer's time (thus, on the eve of the kingdom's destruction), despite the complete lack of any other evidence that the Alans still existed as a distinct social group in Africa. Victor and Procopius, of course, have dominated later discussions of Vandal Africa, and the significance attached to this particular title is likely because of its appearances in their work. The dual-ethnic title has thus been commonly regarded as the default title of the Vandal kings.

But Steinacher's comprehensive survey of the Vandal royal titles ${ }^{404}$ has revealed that its use was actually rare. The only two kings to use it are Huneric and Gelimer, and in limited contexts. ${ }^{405}$ Even the simpler "rex Vandalorum" is uncommon: most of the Vandal royal titulary contains no reference to ethnicity at all. ${ }^{406}$ Most of the time, the kings are referred to with variations on the titles dominus noster and rex (including appended superlative attributes reminiscent of Roman imperial victory ideology, such as invictissimus, clementissimus, or gloriosissisimus). ${ }^{407}$ The sole known royal inscription from Africa, produced under Gelimer, uses the simple Domn (us) [sic] Gelimer. ${ }^{408}$ While avoiding the imperial title itself, these forms clearly evoke imperial precedent, in particular dominus noster, a form long associated with the emperors. Starting with Huneric, it was common practice to combine the two as one, "dominus noster rex," probably a deliberate imitation of imperial forms. ${ }^{409}$

Indeed, the entire edifice of Vandal kingship emulates Roman forms. Procopius informs us that

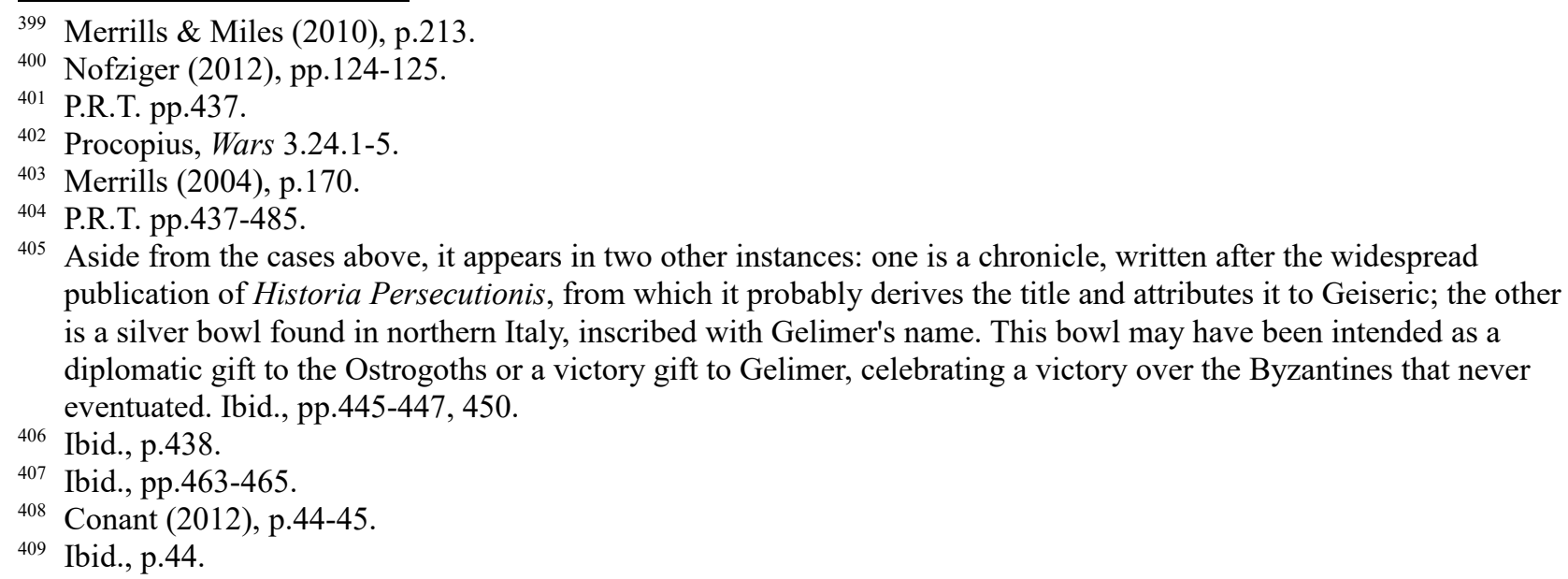


Vandal kings wore imperial purple garments and sat on a golden throne, while their queens went about in carriages, ${ }^{410}$ and Huneric claimed the right to proclaim leges (an exclusively imperial privilege), not merely edicts and praecepta, the sorts of legislation provincial authorities were normally limited to. ${ }^{411}$ Huneric also renamed Hadrumetum, capital of Byzacena, to "Unuricopolis," an arrogation of imperial prerogative. ${ }^{412}$ Given how strongly the Vandal kings imitated Roman precedent, their occasional use of the dual-ethnic title probably does not represent the strong assertion of identity-based monarchy that some commentators have taken it for (especially given the insubstantial nature of Vandal culture we observed in Chapter One). Steinacher offers a plausible alternative: the same two kings to use the dual-ethnic title came to power in a swirl of dynastic violence, and both, for different reasons, faced internal opposition from another branch of the Hasding dynasty. These two kings would have needed to appeal to the military elite to keep power, and Steinacher attributes their use of the title to this purpose, a conservative overture to the glorious past, invoking the language of pre-African times to appeal to a traditionally-minded elite. ${ }^{413}$ The title only appears in moments of tension or crisis: we have no other titulary for Huneric, but Gelimer is referred to in other occasions with non-ethnic titles, such as in the royal inscription mentioned above. Its use thus appears to be a strong exception, not a norm.

Most of the time, the kings stuck to forms imitating imperial titles, casting their monarchy in a Roman light, without reference to ethnicity. The few exceptions to this rule either appear in times of crisis or circulated, possibly, in inner circles of the court, not to be seen by outsiders and consequently hardly visible to us. Where ethnic language does come up, it is generally padded with impeccably Roman references. Felix's ekphrasis from Chapter One, in which Hilderic is called "Vandalirice," makes no mention of the deeds of Hilderic's Vandal ancestors on his father's side, focussing instead on Theodosius, Honorius, and Valentinian, his Roman maternal ancestors. ${ }^{414}$ Reading the poem as an ideological statement, it is significant that Hilderic would want to downplay his Hasding ancestry in favour of his Theodosian connection. If "Vandalirice" is to be read as a proud assertion of non-Roman identity on Hilderic's part, the subsequent lack of reference to any Vandal past is hard to explain. In fact, Hilderic seems to have placed a lot of emphasis on his Theodosian connection, presenting the Vandal monarchy as a fusion of the Hasding and Theodosian families: wall-paintings from his palace in Anclae (mentioned in Felix's ekphrasis, not extant) also prominently displayed the links between the king (and his nephews, Hoageis and Hoamer) and the Theodosians. ${ }^{415}$ Despite the ethnic language of "Vandalirice," Hilderic was interested in portraying his monarchy in highly Romanised and imperial terms.

The attitude displayed by the Vandals towards religious matters was similarly imperial in tone. The emperors took steps to protect the rights of Christians outside their own borders: for instance, the peace terms signed between Justinian and the Persian emperor Khosrow I in 562 contained a separate sub-treaty guaranteeing the rights of Christians in the Persian Empire (and, conversely, the rights of Zoroastrians in the Roman Empire). ${ }^{416}$ At least some of the Vandal kings similarly acted to safeguard the rights of Arians, but their stage was the Roman Empire itself. In 481, after a period of negotiations with the emperor Zeno, Huneric finally allowed the Nicene community to consecrate a new bishop for Carthage. ${ }^{417}$ This was no small matter: the see had been vacant since the death of

\footnotetext{
410 Procopius, Wars 3.9.4-5, 3.9.12.

411 Conant (2012), p.45.

412 Merrills (2004), p.161.

413 P.R.T. pp.473-474.

414 AL $R 215$.

415 Merrills \& Miles (2010), pp. 72, 76.

416 Menander Protector, Fragments 6.1.

417 Burns, Jensen, \& Clarke (2014), p. 72.
} 
Deogratias in exile, twenty-four years earlier during the reign of Geiseric. ${ }^{418}$ The Nicenes were allowed to consecrate whomever they wished, as the emperor had requested, but there was a condition attached. Victor tells us that Huneric requested from Zeno that "the bishops of our religion who are resident at Constantinople and throughout the East are to have... the right to preach to the people in whatever languages they desire and to practice the Christian religion, just as you will have this right.... . 419 Apparently the Romans agreed to this, as Huneric allowed the ordination, but it is difficult to know what impact it actually had on Arian communities in the East. However, in posturing as guardian of Arian rights on an international scale, Huneric took upon himself the imperial role of protector and promulgator of the orthodox faith (as interpreted by the Vandal Kingdom).

These pretensions did not only make themselves known overseas. The creation of the Arian patriarchate in Carthage, a unique move on the Vandal monarchy's part, was recognised by contemporaries as overstepping royal bounds. At the opening of the conference of 484, the Nicene delegation asked who would judge the debate. The king's notary replied "'The patriarch Cyrila has named some people,"' and was met with howls of protest, as the Nicenes "abominated the proud and unlawful title which [Cyrila] had usurped," demanding to know who had given him authority to take it. ${ }^{420}$ This authority could only have come from the king himself, and further demonstrates the imperial pretensions of the Vandal monarchy: the creation of a patriarchate centred on their capital usurps an imperial prerogative (the right to create a patriarch, as attested by Theodosius I's elevation of the theretofore-minor bishop of Constantinople to patriarchal status in 381). ${ }^{421}$ The conference of 484 also demonstrates the kings' willingness to define orthodoxy, just as the emperors $\operatorname{did}^{422}$ In fostering and seeking to define and control a state church, the Vandal kings were walking a path well-trodden by the emperors before them.

This all adds up to a state and monarchy that wanted to be seen, for the most part, as thoroughly Roman in style, but also as legitimate rulers and children of Africa. Their presentation was imperial: they repurposed Roman rituals, titles, and even Roman high culture itself to garner loyalty and promote the legitimacy of their rule. At the same time, they made great efforts to promote their credentials as African rulers, and the physical relics of their rule, such as the Punic symbols on their coinage and their idiosyncratic calendar, reflect this desire to focus their subjects' attentions on Africa and Carthage. Geiseric put Carthage at the centre of Vandal state ideology from the kingdom's early days, and the emphasis he and subsequent Vandal kings placed on it found an echo in the municipal pride of late-antique Roman aristocrats like Florentinus and Luxorius. Luxorius in particular often returns to the well of Carthage for inspiration, celebrating its monuments and its entertainments in a way that breathes credibility into Florentinus' broad-brush picture of a flourishing metropolis. These poets cast the post-invasion Vandals not as outsiders to the city but as both its children and its guarantors.

Given that Florentinus' poem was almost certainly commissioned by Thrasamund, we cannot know what the poet's genuine sentiments were on the matter. Nevertheless, its ideas held a grain of truth that we can verify based on surrounding evidence. Carthage did flourish under the Vandals, as did Africa, perhaps better than it had under imperial administration: agricultural production stayed high, towns remained prosperous, and (perhaps most crucially, from the perspective of a rich RomanoAfrican) the wealth that was once extracted from Africa to feed Rome and pay the imperial army

\footnotetext{
418 Merrills \& Miles (2010), p.181.

419 Victor Vitensis, Hist.Per. 2.4.

420 Victor Vitensis, Hist.Per. 2.53-54.

421 Lee (2013), p.46; Conant (2012), p.46.

422 Conant (2012), pp.46-47.
} 
was kept at home, where it could enrich the locals - at least, the ones that owned property. ${ }^{423}$ The Vandal kings even contributed to this flourishing, with a series of monetary reforms that stimulated the economy. ${ }^{424}$ Procopius himself informs us of the kingdom's excessive wealth, which he uses as an explanans for the Vandals' defeat by Belisarius: Carthage's luxuries and decadence drained their warrior spirit. ${ }^{425}$ Meanwhile, Parthemius' letter shows us that the notion of Vandals as natives of Africa was credible enough to be repeated in private correspondence, and thus had some currency among African elites outside of state propaganda. The Vandals certainly believed it: we have already seen how a unit of Vandals being deported to the eastern frontier, upon overpowering the crew of their transport ship, turned around and sailed straight back to Africa. ${ }^{426}$ They had no other genuine home.

Parthemius also shows us that elite Africans had a sense of national pride, reflected in Fulgentius the Mythographer's tale about Calliope and his staunch identification as Libyan, rather than Roman. ${ }^{427}$ The Vandal government's coinage, in particular its revival of old Punic symbols, shows awareness of this and an attempt to foster it by using specifically African motifs in its ideological broadcasting, also indicated by Florentinus' loud trumpeting of the prosperity of Africa and its preeminence over all other lands. The kings' reluctance to broadcast Vandal identity is equally significant. We saw in Chapter One that Vandal patronage of the arts took very Roman forms, and that Vandalic, while retaining an afterlife as a liturgical language in the Arian Church, was essentially moribund by 534. To this we can add that the Vandal kings presented themselves in as Roman a light as possible. They downplayed the use of ethnic titles in public, reserving them for their inner circles and only dragging them out in times of crisis, and preferred Roman-influenced titles, particularly dominus noster rex. They employed imperial trappings of power, such as the purple robes and golden throne, and routinely usurped imperial prerogatives, renaming cities, convening church councils, and passing leges. They even reoriented civic veneration of the emperors, still practised by the elites of North Africa, towards themselves, ritually affirming links between themselves and provincial elites in Roman style.

Roman responses, at home and abroad, to the kings' assertions of legitimacy are complex, but overall indicate a general acceptance of their right to rule. Their supporters naturally portrayed their rulers as legitimate, as in Florentinus' portrayal of Thrasamund as guarantor of Carthaginian prosperity or Felix's harping on Hilderic's glorious Roman ancestors. But even in Sardinian exile, Fulgentius of Ruspe dated his codex of Hilary of Poitiers' pro-Nicene writings using Vandal regnal dating, which Conant takes as implying that he accepted Thrasamund's political legitimacy even as he opposed his religious policies. This is further borne out by his strenuous attempts to convert the king to the Nicene faith, something he would not have done had he seen Vandal rule as illegitimate. "To Fulgentius, Thrasamund's right as a Vandal to rule his kingdom was not in question. The only question was whether [he] would rule according to God's eternal law or against it." ${ }^{28}$ The imperial government, while its actual relations with Africa varied, also accepted the validity of Vandal institutions: Justinian's invasion of Africa was initially undertaken not as a conquest but at the instigation of Romano-African partisans of Hilderic, who fled to Constantinople after Gelimer overthrew Hilderic in a coup; the justification for the invasion was not that Africa was once Roman

\footnotetext{
${ }^{423}$ Merrills \& Miles (2010), p.176.

${ }^{424}$ These reforms occur simultaneously with developments in Italy, and it is impossible to say which kingdom pioneered them: given the high level of trade and free circulation of coins between Italy, the western Mediterranean islands, and Africa, they may even have developed jointly between the two realms. In any case, they proved so successful that they were copied by Anastasius in his 498 and 512 currency reforms. Merrills \& Miles, pp.174-175.

425 Procopius, Wars 4.6.1-23.

426 Ibid., 4.14.17-22.

427 Fulgentius, De Aetat., preface.

428 Conant (2012), p. 195.
} 
but that Gelimer's accession was illegitimate by Geiseric's laws. ${ }^{429}$ Belisarius even published a declaration to this effect during the invasion. ${ }^{430}$ That the Byzantines justified themselves via reference to Geiseric's succession laws even while overthrowing his kingdom bespeaks a recognition of the legitimacy of those laws. In other words, the Vandal regime successfully asserted its legitimacy on both a national and international level.

Their cultural efforts also seem to have found an audience in the African populace. This essay has already noted the substantial cultural fusion of Vandals and Romano-Africans at an elite level, and Parthemius' letter further demonstrates that the African aristocracy was quite willing to embrace the Vandals as kin to themselves: inclusivity, not alterity, is the theme of his correspondence. Some Romano-Africans even risked their lives for the Vandal cause during the invasion: peasants fought against the Byzantines, Romano-Africans were in the Vandal army, and Belisarius even saw fit to impale a local noble, Laurus, on a hill overlooking Carthage, to terrorise other Africans into not plotting with Gelimer against him. ${ }^{431}$

If identity is in large part defined by narratives laid out by the dominant groups in society, as Barth says ${ }^{432}$ then the Vandals' messages of African pride and unity between Romano-Africans and Vandals under an African umbrella must have had a strong impact on the identities of their African subjects. Although we lack a substantial written record from Byzantine Africa to confirm how deeply the changes went, the Vandal government put a great deal of effort into creating a cultural milieu that fostered this trend away from affiliation with the empire and towards affiliation with home and one another. Not only did they trumpet their legitimacy as the rulers of Africa, but they also trumpeted the status of Africa as an independent place with its own heritage and traditions, prominent and powerful on an international stage, its native sons - Romano-African and Vandal alike, as we saw with Sigisteus - equal to any competitor. These cultural efforts had an impact that outlived the Vandal Kingdom itself: Fulgentius' post-Vandal pride in Africa was mirrored, as we shall see in the conclusion, by assertiveness and recalcitrance in the face of Byzantine rule by people at all levels of African society.

\footnotetext{
429 Merrills \& Miles (2010), p.229.

430 Procopius, Wars 3.16.11-15.

431 Merrills \& Miles (2010), p. 239.

${ }^{432}$ Barth (2006), p.31.
} 


\section{Conclusion}

The Vandal kings put a great deal of effort into creating a milieu in which their people and the Romano-Africans could likewise come together into a single body. If ethnic identity is determined by a process of boundary maintenance, then the Vandals' lack of maintenance around their own boundaries suggests a people very eager to acclimatise themselves to their subjects and their subjects to themselves. They adopted Romano-African high culture to the extent that we have trouble determining the identity of certain individuals, such as Eugetus from Chapter One. Even the most defining indicia of Vandal identity in Africa, military service and access to the sortes Vandalorum, were available to Romano-Africans. They fostered an African church, answerable to them, that incorporated aspects of Vandal and local Christian culture: the Vandalic liturgy on the one hand, the practice of rebaptism on the other. To achieve unity in their realm under the umbrella of this church, they went to great, sometimes even violent lengths to spread it. In doing so, they created the grounds for the kind of coming-together of peoples under the umbrella of religion that Gregory and Cassiodorus espoused, albeit in different form. Furthermore, in their promotion of Punic motifs, Carthaginian primacy, and identification of themselves with Africa's prosperity (and Africa with their own prosperity), we can see traces of their attempts to promote local African identity among their people.

Individual reactions to this varied in Africa, as we have seen. Many, such as Parthemius or Florentinus, were quite willing to join the Vandals in this pride and celebration of Africa's wealth and civilisation, and indeed to regard the Vandals as every bit as African as themselves. Large numbers of Africans, both elite and everyday, crossed over into their national Arian Church. The ebbing of violent persecution within Africa in the kingdom's later years bespeaks an increasingly interwoven society, in which Vandals and Romano-Africans were ever more reconciled with one another. The self-identification of individuals like Corippus or Fulgentius the Mythographer as Libyan or Punic, rather than Roman, points to a continued identification with Africa on the part of the local elite even after the kingdom's fall, but evidence from post-Vandal authors indicates that these changes did not merely make themselves felt among the provincial elite. One thing Procopius is confident about is that his $\Lambda i \beta v \varepsilon \varsigma$ are not identical to P from the Eastern Empire. ${ }^{433}$ This cannot merely be a reference to Romano-Africans' status as citizens of a foreign realm: even after the conquest, the Libyans do not become Romans. They are descended from Romans, ${ }^{434}$ they become subject to the Romans, ${ }^{435}$ they fight for the Romans, ${ }^{436}$ and they find a wretched peace after the Romans finish driving off the Berbers, ${ }^{437}$ but they are never equated with or referred to as Romans. Alterity, in other words, is present throughout all of Procopius' discussion of the Romano-Africans, even after political unity with the Eastern Empire was achieved.

The sudden Byzantine conquest of Africa prompted an abrupt volte-face on the part of the old provincial elite. The Vandal rulers to which they had spent the last century accommodating themselves, with which they had been in an advanced state of cultural merger, were packed up and shipped off to the Persian frontier almost overnight, their remnants reduced to a handful of rebels and fugitives holed up with Berbers in the African wilderness. Instead, they were faced with a group that claimed they arrived in Africa to restore Roman rule to formerly-Roman lands, but whose

\footnotetext{
433 Conant (2012), p.196.

434 Procopius, Wars 3.16.2-4.

435 Ibid., 4.20.32.

436 Ibid., 4.23.20-23.

437 Ibid., 4.28.51-52.
} 
Romanness had diverged extensively from their own. These new rulers, for their part, regarded Romano-Africans as not fully Roman. While they acknowledged the Africans had been Roman in the past, they were now something else, changed by their time under non-Roman rule. We have seen Procopius' ongoing alterity towards the Africans in his Wars, but this was not just his view. The imperial administration appears to have had suspicions about the trustworthiness of the local elite. While soldiers were conscripted in Africa as usual, ${ }^{438}$ its military staff was almost entirely composed of Romans from elsewhere in the Empire throughout the Byzantine period, ${ }^{439}$ unlike more secure provinces such as Egypt, where local commanders predominated at the local level. ${ }^{440}$

This was a sensible precaution. Despite the relative swiftness of the conquest of the Vandal Kingdom, Africa was a turbulent province in the Byzantine period, with frequent mutinies and civil strife. Large parts of De Bello Vandalico discuss the three mutinies of Stotzas, John (a.k.a. Stotzas junior), and Guntarith, Roman commanders who tried to break away and establish a new African kingdom. ${ }^{441}$ Its wealth and relative distance from Constantinople also made it a good base for usurpers: the exarch Heraclius the Elder used it in his successful revolt against Phocas. Similar anxieties probably lay behind the recall of the praetorian prefect George, in disgrace, in $642 .{ }^{442}$ Another exarch, Gregory, declared himself emperor in Africa in 646, at the Africans' behest: this time, though, he was declaring himself an independent ruler, much as the previous generations of mutineers had. ${ }^{443}$ Commanders building bases in Africa from which to launch insurrections were thus a major problem for the Byzantines, from Belisarius' conquest in 534 to that of ibn an-Nu'man in 697.

But it was not merely rogue commanders that caused problems in Africa: the populace also proved to be restive. During the invasion, African peasants fought the Byzantines on the Vandals' behalf, killing slaves and servants from Belisarius' army who fell into their hands and presenting their heads to the king for reward, ${ }^{444}$ and the impalement of Laurus on suspicion of collaboration with Gelimer demonstrates Belisarius' anxieties about Africans conspiring against the invaders. After the kingdom fell, some Africans joined with mutineers such as Guntarith to fight for an independent African kingdom. ${ }^{445}$ Others may have joined the Berbers: von Rummel argues that the Frexes, the tribe of Antalas (a powerful Berber leader, who initially allied with the Byzantines but later turned against them after the Byzantine general Solomon, at this time supreme commander in Africa, killed his brother), ${ }^{446}$ were significantly swollen by mass absorption of rural Roman populations during the post-invasion breakdown of order. ${ }^{447}$

Even the more peaceful aspects of Africa's integration into the Empire caused problems. Justinian's plans for a slow transfer of property from the Arian to the Nicene church angered African Nicenes, who demanded faster confiscations. ${ }^{448}$ When the emperor gave in to those demands, he in turn outraged the Arians, both local and in his army. This was a key factor in Stotzas' mutiny, the first of the great rebellions that threatened the entire Byzantine project in Africa ${ }^{449}$ During the Three

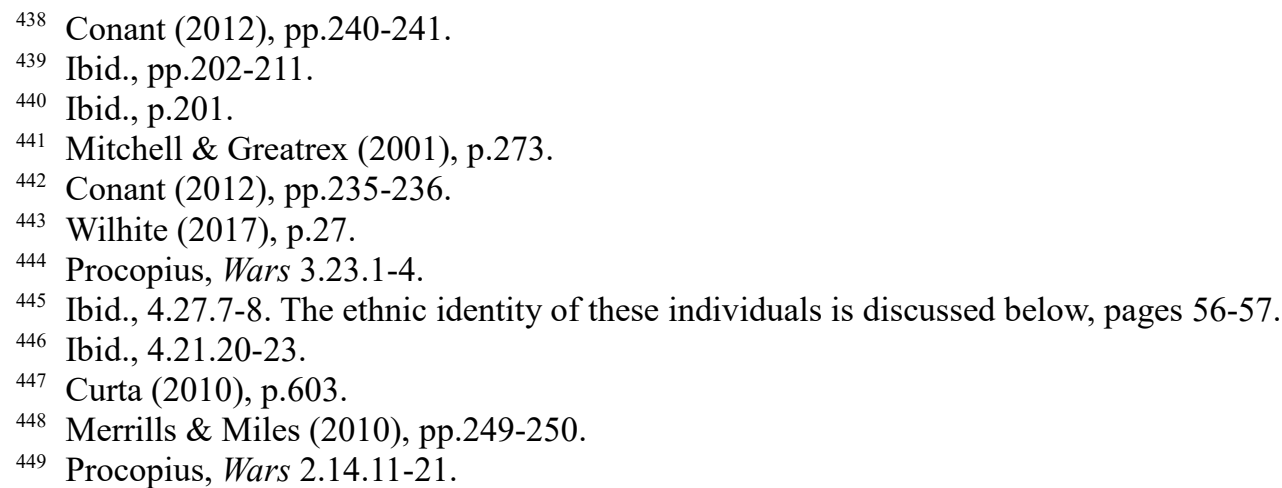


Chapters Controversy, ${ }^{450}$ Romano-African Nicenes proved themselves among the most inveterate opponents of Justinian's attempts at compromise with Eastern Monophysites. When Pope Vigilius reluctantly assented to Justinian's redefinition, thus bringing all five patriarchs on board, African bishops responded by excommunicating the pope and sending a treatise to Justinian in defence of the Three Chapters that, in modern editions, runs to almost 400 pages. ${ }^{451}$ In the end, the Three Chapters project foundered on the rocks of hardline opposition from both sides; thus, the conquest of Africa played no small part in wrecking Justinian's religious policy. Africa would go on to sabotage other attempts at reconciliation with the Monophysites. Having freed the African Nicenes from the Vandals, the emperors thus found every attempt they made to reshape Christian orthodoxy condemned and opposed from Africa.

This rebelliousness and religious inflexibility did not come out of nowhere. During the Vandal century, grave differences had come to appear between the Roman population of Africa and that of the Eastern Empire. We have seen that the Vandals and the Romano-African upper class had come very close to a cultural fusion by the time Belisarius landed on African shores. Our best information for how much ordinary Africans had changed over the Vandal century comes from non-Vandal sources writing after the kingdom's demise. We have seen Procopius othering the Romano-Africans throughout the Wars, acknowledging their Roman descent but never fully equating them with the Romans. There is a sense that, while the Libyans may once have shared equally in Romanitas, they are something different now, not full participants in Roman culture. ${ }^{452}$ A century under Vandal rule had changed them, in such a way that they were no longer altogether Roman.

We might dismiss this view as sniffy hauteur from a man who grew up in the Eastern Empire, and whose Romanness thus never had to adapt to being ruled by non-Romans. But, remarkably, nonRoman sources confirm Procopius' view. The Arabic chronicler ibn 'Abd al-Hakam, writing in the seventh century, when Muslim raids had started to penetrate into Byzantine Africa, described the province as home to three kinds of people: Berbers, Rüm (Romans or Byzantines), and Afäriq (Africans). ${ }^{453}$ This is a significant distinction for an outsider to make. Even from a non-Byzantine perspective, the Africans were not fully reconciled to Eastern-Roman culture or identity by the time of the first Muslim attempts on Africa, and enough differences persisted for Arab chroniclers to consider the two peoples as separate.

The Vandals certainly encouraged this - we can read their promotion of pride in Africa and Carthage's splendour and prosperity in Florentinus' panegyric to Carthage - and the coin motifs and widespread adoption of their calendar suggest they were interested in promoting similar images of African unity, strength, and prosperity across their entire kingdom. The kings endorsed a sense of Africanness, reorienting people's gazes away from the Empire and towards local affiliation and pride in Africa, encouraging Africans to see their home as the equal of any other realm in prosperity and culture, while at the same time portraying themselves as just as African as any of their RomanoAfrican subjects. The reactions of individual Romano-Africans to this vary, but we see local pride in figures like Parthemius or Luxorius during the kingdom's lifetime, and the continuing selfidentification of Corippus and Fulgentius the Mythographer in African terms (indeed, Fulgentius' sense of superiority in being a Libyan) tell us that pride in Africa lasted beyond the fall of the

\footnotetext{
${ }^{450}$ An attempt by Justinian to mend the schism that had broken out, after the Council of Chalcedon in 451, between the official imperial church and a large group in Egypt, Syria and other eastern provinces (conventionally called "Monophysites," "Miaphysites," or "Cyrillians") over the nature of the relationship between the human and divine parts of Christ's person. Despite Justinian's efforts, as well as those of previous emperors such as Zeno and later ones such as Heraclius, this schism was to prove lasting.

451 Conant (2012), pp.319-320.

452 Ibid., p.196.

453 Ibid., p.196 n.1.
} 
Vandal Kingdom, a suggestion confirmed by Procopius' pervasive alterity towards Africans in the Wars.

An illustrative case of this alterity is that of the troops of Guntarith (variously rendered as Gontharis, Guntarit, etc.), a general who mutinied against the Romans in Africa. Guntarith first appears in Procopius as a Roman commander, a bodyguard of Solomon sent to fight the Berber leader Iaudas at Mount Aurasium. ${ }^{454}$ Later, he was appointed $d u x$ of Numidia, and plotted with the Berbers to make himself ruler of Africa. This plot ended with Guntarith, having seized Carthage via trickery, murdered at a banquet by Artabanes, an officer from the Armenian Arsacid royal dynasty. ${ }^{455}$ Roman rule was thus restored to Africa.

Procopius specifies that, after the earlier mutiny of Stotzas (in which the remaining Vandals in Africa took part), all Vandals in the country were deported again. ${ }^{456}$ But a large number of Vandals subsequently appear as soldiers of Guntarith, without explanation. ${ }^{457}$ The answer to where they came from can be found in Procopius' treatment of other enemies of the Roman government in Africa. Although Stotzas' troops were composed largely of Roman mutineers, Procopius characterises them as "barbarians" in a speech he attributes to Belisarius, but when Germanus, another Roman commander in Africa, offered amnesty to Stotzas' troops, some defected and rejoined the Roman side - at which point, in the historian's eyes, they instantly became Romans again. ${ }^{458}$ An important indicium for Romanness in Procopius is thus loyalty to the Roman state. Soldiers who switched sides changed their identity, as recognised by others: Roman troops who came to Africa with Belisarius became barbarians when they rebelled, but Roman again when they rejoined the imperial cause. Ethnic identity was flexible during the wars in Africa (and likewise Italy), and an individual's identity was dependent on their actions and allegiance as much as anything else. ${ }^{459}$

With all the Vandals deported from Africa, the Vandals under Guntarith must not have been considered Vandal at the time of the deportation; therefore, their identity as recognised by imperial commentators must have changed from something else. Procopius distinguishes them from Roman mutineers and from Berbers, ${ }^{460}$ so they cannot be related to either party. The only source left for these new Vandals is the Romano-African populace itself. We have seen in Chapter One that armed service was the key indicium for Vandal identity in the Vandal Kingdom itself, and that RomanoAfricans could become Vandal by joining the army. Ethnicity in the African wars was determined largely by one's actions, and we already know that African peasants tried to resist the Roman army during the invasion via guerrilla actions. I therefore advance the theory that the Vandals under Guntarith were Romano-Africans similarly taking up arms against the Roman state. This is perfectly plausible based on evidence from the Ostrogothic Kingdom during the invasion. Italians who took up arms in the Gothic cause were regarded as Gothic by Procopius, ${ }^{461}$ and the problem of Guntarith's non-Vandal identity can be explained with reference to the fact that Gothic troops were perfectly happy offering Belisarius the throne of Italy (even Witigis, the Gothic king, was willing to abdicate his throne for this): ${ }^{462}$ thus, the defining Gothic cause was not so much for a Gothic

\footnotetext{
454 Procopius, Wars 4.19.6-10.

455 Ibid., 4.25.1-28.42.

456 Ibid., 4.19.4-5.

${ }^{457}$ Ibid., 4.27.7-8.

458 Mitchell \& Greatrex (2001), p.273.

459 Ibid., p.274.

460 Procopius, Wars 4.26.1-27.8.

461 Amory (1997), pp.168-194.

${ }^{462}$ Procopius, Wars 6.29.17-30.30.
} 
kingdom as for a local government, rather than Eastern rule. ${ }^{463}$ Similarly, Africans fighting for a local African kingdom became Vandals in the eyes of Procopius regardless of who their leader was, as indeed they had become by the standards of the Vandal Kingdom.

In fact, Vandal identification would eventually swallow Guntarith himself. Guntarith is not referred to as a Vandal in the relevant parts of Procopius or Corippus, the primary sources covering his mutiny, and his original role as Solomon's bodyguard suggests he came over during the invasion. However, less than fifty years after his death, Roman authors such as the biographer of Vigilius in the Liber Pontificalis already identify him as a "king of the Vandals," "464 a trend that continues in later Roman chronicles. ${ }^{465}$ Greatrex takes this blurring of Guntarith's identity by Roman writers to make him a Vandal as suggesting that, in a post-invasion context, political loyalty to the old regime, or even disloyalty to the Empire, may very well have become an indicium of non-Roman Vandal identity. This assumption matches evidence from other cases: most commentators describe the failed usurper Vitalian's forces as barbarian, but Marcellinus comes, sympathetic to Vitalian, identifies them as Roman. ${ }^{466}$ Whether people are considered Roman or barbarian thus depends on their actions and the sympathies of the person writing about them. Guntarith's aim (ousting Roman authority from Africa and establishing a kingdom) was identical to that of the Vandals serving under him: in the eyes of Roman commentators, this was enough to mark him as one of them.

The fact that Romano-Africans continued to subscribe to African identity even after the Byzantine conquest indicates that their cultural policy had some lasting impact in detaching their people from Roman cultural and political identification and orienting them towards Africa, to which Procopius and al-Hakam bear witness. Indeed, as we saw, the appearance of Vandals out of thin air to fight in the armies of Guntarith suggests that Vandal identity remained a valid choice even after the fall of the kingdom, for those Africans who wanted to see an Africa independent of Eastern rule. The people of Africa would express this sense of independence over and over throughout the Byzantine period. They fought as Vandals, they fought as Berbers, and even as late as 646 they encouraged the exarch Gregory to declare independence from Constantinople. We see here the continuing vitality of identification with Africa, rather than with the Empire. Long after the death of the Vandal Kingdom itself, many Africans under renewed imperial rule came to the conclusion that they would be better off without the Roman state.

This was not universally the case, of course, and plenty of Africans co-operated gladly with the new regime. But even there, changes originating in the Vandal century came to cause significant tension, even renewed persecution, when it came to incorporating the African Church into that of the wider empire. A sense of independence and willingness to defy authority to preserve their view of orthodoxy was a hallmark of African Christianity, ${ }^{467}$ and the Nicene Church's experience under Arian monarchs had instilled this rigour into the heart of what it meant to be Nicene in Africa. ${ }^{468}$ Identity in the late-antique world was connected to religion, and following the right creeds and councils was an important part of identification as a Roman. We have seen how Romano-African secular authors abandoned the very label of "Roman" in Vandal times, preferring more local forms such as Fulgentius the Mythographer's "Libyan" or Luxorius' and Corippus' "Punic." This was likely encouraged by the Vandals, who promoted similar forms of African identity. Outward expression of Romanitas in the Vandal Kingdom was left to Nicene polemicists, whose conception

\footnotetext{
463 Amory (1997), p.171.

${ }^{464}$ Loomis (1965), pp.153-154.

465 Mitchell \& Greatrex (2001), p.273.

466 Ibid., pp.272-273; for Marcellinus' sympathies, Croke (2001) p.98.

467 Wilhite (2017), p.8.

468 Merrills \& Miles (2010), p.252.
} 
of Romanness lay in unwavering orthodoxy. ${ }^{469}$

But Romanness, in the sense of being a citizen of the temporal Roman Empire, was in many ways becoming secondary to this stringent orthodoxy. Conquest by heretics and separation from the empire that defined them had prompted soul-searching in Romano-African Nicenes, and even in the earliest days of Vandal Africa, Quodvultdeus had posited along the lines of Ambrose of Milan that a Christian's first loyalty lay not with any worldly power but with the kingship of Christ. ${ }^{470}$ While Victor may have written his Historia as a plea for help from the East, Nicene stalwarts like Fulgentius of Ruspe acknowledged the political legitimacy of the Vandal kings even as they defied him in religious matters. This notion of accepting the temporal authority of the local ruler but asserting one's spiritual independence is a marked break from the Byzantine position, in which loyalty to the emperor and adherence to his interpretation of the faith were becoming increasingly synonymous, ${ }^{471}$ and it would cast a long shadow in the century-and-a-half of Byzantine rule.

African Nicenes, whose identity was rooted in rigorous adherence to the faith in the face of heretical rulers, were thus hardly going to accept compromising their beliefs to placate a different group of heretics. For hardline Nicenes, Vandal rule had represented a revival of the Great Persecution: the Vandal kings were routinely compared to persecuting Roman emperors, while the Nicenes got to reverse the role they played against the Donatists and pose as martyrs. Important to this narrative was the foulness of the temporiser, the traditor who compromised their faith to survive, and the glory of the contrasting figure, the martyr who died rather than recant the true faith. ${ }^{472}$ The ideal Christian, in the African view, gave witness even until their death. ${ }^{473}$ As a result, by the time of the invasion, being a Nicene in Africa had become tightly bound up with strict, defiant adherence to orthodoxy, "an active sense of suspicion and victimhood when it came to secular authority" 474 that ruled out the kind of flexibility the emperors needed from their party to achieve reconciliation with the Monophysites.

Accordingly, the African clergy looked on the Three Chapters affair in horror, an attempt to rewrite Chalcedon, and through it Nicaea itself: "what shall be lasting," cried Ferrandus, a Carthaginian deacon, "if what the Chalcedonian council established is called into question?" 475 The stakes could not have been higher. In the period of Vandal persecution, defending the Nicene Creed against a coercive, heretical government was at the heart of what it meant to be a good Christian, and this left lasting impressions on the African Nicene psyche. Accordingly, the Africans dug in their heels, even against the emperor and all five patriarchs. Despite a campaign of exile, excommunication, and imprisonment against Africa, the emperors, as we have seen, blinked first. ${ }^{476}$ Through sheer obstinacy, Africa carried the day.

But the Monophysite controversy continued, and imperial meddling with orthodoxy was to further try Africans' patience. Even after the dust settled on the Three Chapters, Africa would play a major oppositional role in the Monothelite attempt at compromise with the Monophysites in the midseventh century. ${ }^{477}$ This particular dilution of the faith was the last straw: imperial endorsement of Monothelitism, and the reprisals against dissidents that came with it, so exasperated African

\footnotetext{
469 Conant (2012), p.375.

470 Ibid., pp.176-177.

471 Ibid., pp.361.

472 Whelan (2018), p.119.

473 Wilhite (2017), p.145.

474 Merrills \& Miles (2010), p. 252.

${ }^{475}$ Conant (2012), pp.319-320.

476 Merrills \& Miles (2010), p.252.

477 Conant (2012), p.351.
} 
rigourists that, in the end, they were willing to break with the Roman state to preserve their faith. Gregory's uprising in 646 was, significantly, encouraged by the African populace as a reaction against imperial religious meddling. ${ }^{478}$ Given the choice between Chalcedon and Constantinople, the Africans chose Chalcedon. The two streams of African assertiveness, political and theological, thus met in the figure of Gregory and his attempt at an independent African empire based on orthodoxy, rather than prevarication in favour of eastern heretics. In this, it could be argued, the Africans were following a path trodden by Isidore of Seville, who encouraged good, orthodox Romans to detach themselves from an empire that had become rotten with heresy.

Gregory's rebellion came to nothing, of course, as the exarch-cum-emperor died fighting against Arab invaders under 'Abdallāh ibn Sa'd in $647 .{ }^{479}$ Muslim forces ravaged Africa for five decades, until a final period of fighting in 697 saw the Byzantines permanently expelled from the province. ${ }^{480}$ This mass destruction and death prostrated both the province and its church: once proverbially rich, Africa had by Carolingian times become a byword for poverty, with Frankish charity propping up the church and Christians there. ${ }^{481}$ The African Church that twice shouted down the emperor and the whole church was reduced, over the four centuries of its certain survival, to utter dependence on the popes. ${ }^{482}$ Under such circumstances, it is no wonder that we hear little more about Africans trying to assert their independence from the empire in the last decades of Byzantine rule.

Yet much of the turbulent history of Byzantine Africa, and what we can see of Christian history in Africa after the Muslim conquest, can be explained with reference to developments during the Vandal century. Between the Vandal conquest of Africa and the Byzantine conquests of the Vandals and Ostrogoths, Roman identity in the Western Mediterranean became increasingly decoupled from the Roman empire, as the withdrawal of imperial authority from the West left Western Romans to make accommodations with the new political order. ${ }^{483}$ Likewise, the new ruling elites had to come to terms with their subjects, which they largely did by taking up local Roman culture and promoting formulations of national unity based on religion, as we saw with their historical writers, Gregory of Tours and Isidore of Seville. In western realms that survived long enough, such as France, these accommodations led eventually to the complete cultural merger of the local Roman elite, and eventually the Roman population as a whole, with their rulers.

A similar process was visibly played out in Africa during the lifetime of the Vandal Kingdom. The Vandals made overtures to the Romano-African elites based on shared culture and celebration of Africa. Their monarchy was unabashedly modelled on that of the emperors, and they promoted the glory and prestige of Africa and Carthage, encouraging civic and local pride through their coinage, their calendar, and their panegyric poetry. They fostered national unity through their patronage of the Arian Church, which they centred on Africa and made an integral part of their definition of a local citizen, and which they exported to the Romano-Africans with considerable success. These efforts found an audience in the local population: Procopius and al-Hakam testify to the changed nature of the African populace at the end of, and well after, the Vandal century. Over time, some Africans' identification with the homeland even came to supersede their affiliation with the Romans. We saw this in their reactions to the Byzantine invasion, where local nobles plotted against Belisarius with Gelimer, to the extent that the general had to impale one of them to end the intrigue. Likewise, after the Vandals had been deported, Africans continued to rise up against the Roman

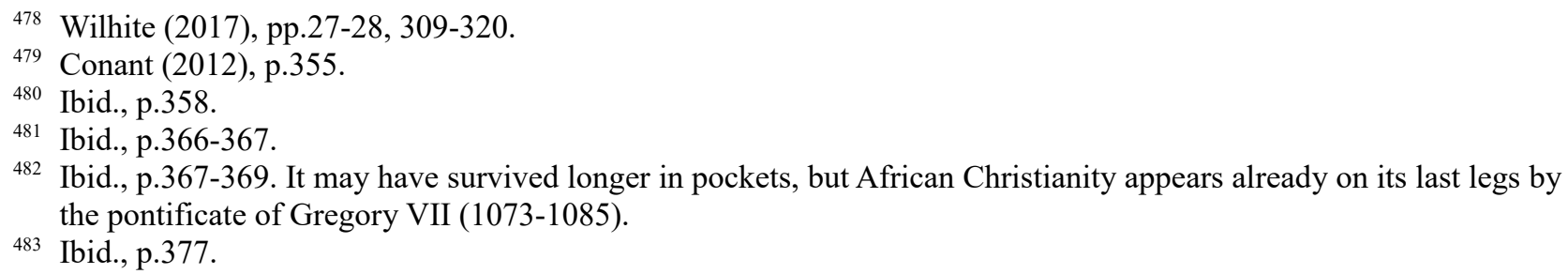


state. By taking up arms, they crossed the last barrier between themselves as a civilian population and the Vandals as a martial one, hence Procopius' identification of these armed Africans as Vandals. Even in 646, long after Vandality and Arianism had stopped being relevant in Africa, Africans supported Gregory in his bid for an African empire. The Vandal Kingdom may have vanished, but the African, non-Roman identification the Hasdings had sponsored had a vitality that long outlasted them.

It was left to the Nicene Church to espouse Roman identity in Vandal Africa. But their vision of Romanness, as we have seen, was based not in terms of political allegiance to the Roman state but in rigorous adherence to the church councils, creeds, and doctrines that had come to form the approved version of Christianity in the West. This redefinition was an adjustment to reality, allowing an individual to be a functioning member of the new, usually Arian states without compromising their faith. When the Eastern Empire absorbed these Christians, they found them curiously intractable, less amenable than many easterners to compromise in the name of unity. The Africans represented this most of all: we saw how the Vandal persecutions hardened African Nicenes against what they perceived as surrendering the cherished articles of their faith. African Nicene Romans had clung to strict orthodoxy to preserve their identities against both religious and cultural pressure from the Vandals. This uncompromising nature led them to oppose any attempts at conciliation with heretics by the emperors, as to accept compromise would be to give up an important part of themselves. Thus, on its incorporation into the Empire, Africa became a constant thorn in the side of imperial attempts to reshape doctrine in the name of political consensus. This path, too, led to Gregory's orthodox revolt.

What had become of the Romano-Africans? As Procopius informs us, their Romanness changed during the Vandal century into something else, no longer compatible with the Romanness of the Eastern Empire. Even those who had clung to Roman identity had made it something other than the Romanitas of the East, defined by loyalty to Christ the emperor, not the worldly emperor in Constantinople. Habetdeum, a bishop who suffered forced rebaptism under the Vandals, made this explicit, telling his tormentors that he composed in his heart a record of his suffering: "the angels wrote it down, and I sent it to my emperor for him to read." ${ }^{484}$ It is clear that Habetdeum's emperor was God: angels, after all, wrote the report. This break with Romanness, less dramatic in the initial stages of Justinian's conquest than the cultural break that led to Vandal uprisings and impalings, would in the long run become a life-or-death matter: African priests were still locked in struggle with the imperial church even as their homeland went down in flames in the late 640s. Yet both shifts in identity, local affiliation and religious inflexibility, were to find their culmination in the insurrection of Gregory for an independent Africa free of compromise and heresy. The period of Vandal rule, however vanished that rule might have been, had made Africans' ideas about their identity and religious practice, I believe, utterly incompatible with those of the Easterners. In the turbulence and intransigence of the African provinces under Byzantium, then, we see the rippling aftermath of changes wrought by Vandal hands.

\footnotetext{
484 Victor Vitensis, Hist.Per. 3.46.
} 


\section{Appendix One: timeline of the Vandal Kingdom}

\begin{tabular}{|c|c|c|}
\hline Geiseric & $435-477$ & $\begin{array}{l}\text { 435: Vandal Kingdom established, with capital at Hippo Regius. } \\
\text { - 439: Geiseric seizes Carthage, shifts capital there. } \\
\text { - 442: Valentinian III and Geiseric make peace. Vandals confirmed } \\
\text { in control of Africa, Numidia, and Tripolitania. Western Empire } \\
\text { gets Mauretania in exchange. } \\
\text { - Mid-440s: Eudocia, Valentinian's daughter, betrothed to Huneric, } \\
\text { Geiseric's son. } \\
\text { - 454: Geiseric allows the Nicenes of Africa to appoint a new } \\
\text { metropolitan of Carthage, Deogratias. } \\
\text { - 455: Petronius Maximus kills Valentinian III. Eudoxia, widow of } \\
\text { Valentinian, writes to Geiseric for help. Vandals sack Rome, take } \\
\text { Eudoxia and her daughters back to Africa. } \\
\text { 458-461: Majorian, Western Emperor, attempts to destroy the } \\
\text { Vandal Kingdom. Vandals defeat his fleet at Cartagena in } 461 . \\
\text { 468: Western and Eastern Empires combine forces to destroy the } \\
\text { Vandals but are defeated at Cape Bon. } \\
\text { 476: Geiseric signs an eternal peace with the Eastern Empire. } \\
\text { The last Western emperor, Romulus Augustus, is deposed by his } \\
\text { general Odoacer: the Western Empire is thus abolished. Vandals } \\
\text { return Sicily to Odoacer, now ruler of Italy. } \\
\text { - January 477: Geiseric dies. }\end{array}$ \\
\hline Huneric & $477-484$ & $\begin{array}{l}\text { 480: Huneric negotiates treaty with Eastern Emperor Zeno to } \\
\text { allow Nicenes of Africa to appoint a new metropolitan of } \\
\text { Carthage. Eugenius is elected metropolitan. } \\
\text { - 483: Aures Revolt. Berbers of Mount Aurasium rebel from the } \\
\text { Vandal Kingdom. } \\
\text { - February 484: Great debate between Arian and Nicene bishops. } \\
\text { Huneric begins persecution of Nicenes. } \\
\text { - December 484: Huneric dies. }\end{array}$ \\
\hline Gunthamund & $484-496$ & $\begin{array}{l}\text { 489-491: Theodoric the Ostrogoth invades Italy, kills Odoacer. } \\
\text { Gunthamund takes advantage of the confusion to invade Sicily. } \\
\text { Peace treaty divides the island between Vandals and Ostrogoths. } \\
\text { - 490s: Major economic reforms. }\end{array}$ \\
\hline Thrasamund & $496-523$ & $\begin{array}{l}\text { - 500: Thrasamund marries Amalafrida, sister of Theodoric. } \\
\text { - 508/509: Thrasamund expels } 80 \text { Nicene bishops to Sardinia. }\end{array}$ \\
\hline Hilderic & $523-530$ & $\begin{array}{l}\text { 523: Hilderic ends persecution of Nicenes. } \\
\text { - 530: Hardline Arian faction, led by Gelimer, launches coup. } \\
\text { Hilderic and his nephews are imprisoned. }\end{array}$ \\
\hline Gelimer & $530-534$ & $\begin{array}{l}\text { - June 533: Byzantine fleet leaves Constantinople. } \\
\text { - August 533: Byzantine fleet lands in Africa. } \\
\text { - September 533: Belisarius takes Carthage. } \\
\text { - Winter 534: Gelimer surrenders to Belisarius. Vandal Kingdom is } \\
\text { abolished. }\end{array}$ \\
\hline
\end{tabular}




\section{Appendix Two: images}

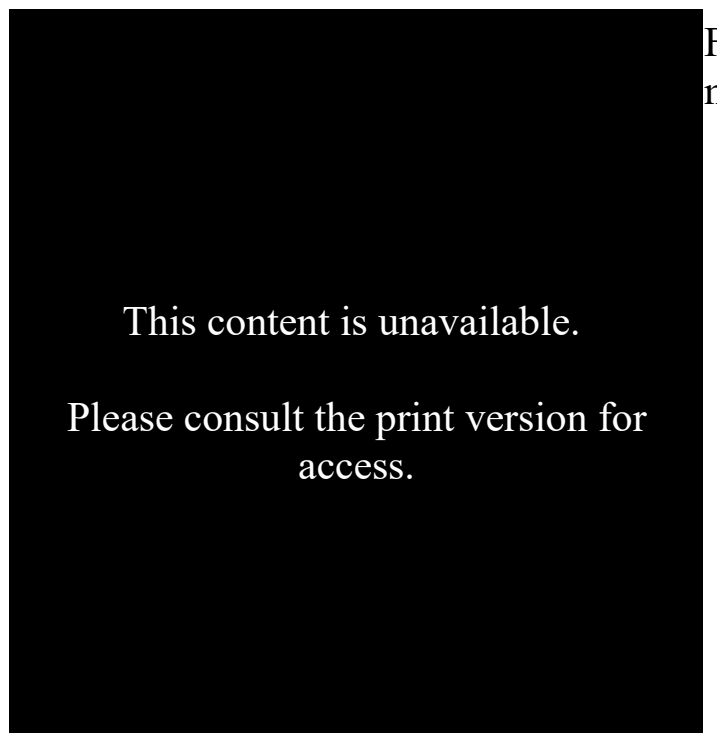

Figure 1: Gold aureus of Constantine I, with moustache. Siscia RIC VI 152

This content is unavailable. Please consult the print version for access.

Figure 2: the Bordj-Djedid Mosaic, featuring its enigmatic rider. Excavated at Bordj-Djedid in 1857. British Museum exhibit number 1967,0405.18AN743016001.

Figure 3: Consular diptych of Rufus Gennadius Probus Orestes, 530 AD, carved ivory. Athalaric is the figure on the left. Museum no. 139-1866, (C) Victoria and Albert Museum, London. 
This content is unavailable. Please consult the print version for access.

Figure 4: Vandal silver coin of Hilderic, with Lady Carthage on the reverse. Oxford: Heberden Coin Room, Ashmolean Museum. Photo originally from Clover (1986).

This content is unavailable. Please consult the print version for access.

Figure 5: Vandal 42 nummi coin. Note the horse's head on the reverse. Cambridge: Fitzwilliam Museum. Photo originally from Clover (1986). 


\section{Bibliography}

- Abramson, Marc Samuel. 2008. Ethnic identity in Tang China. Philadelphia: University of Pennsylvania Press.

- Amory, Patrick. 1997. People and identity in Ostrogothic Italy, 489-554. Cambridge: Cambridge University Press.

- Anthologia Latina, edited by A. Riese. 1894. Leipzig: B.G. Teubner.

- Arnold, Jonathan J. 2014. Theoderic and the Roman imperial restoration. New York, NY: Cambridge University Press.

- Augustine, Roland Teske, and Boniface Ramsey. 2004. The works of Saint Augustine: a translation for the 21st century. Part 2, Vol.3: Letters 156-210 (Epistulae). Hyde Park, NY: New City Press.

- Bagnall, Roger S. 2010. Egypt in the Byzantine world, 300-700. Cambridge: Cambridge University Press.

- Barnwell, P. S. 1992. Emperor, prefects \& kings: the Roman West, 395-565. Chapel Hill: University of North Carolina Press.

- Barth, Fredrik. 2006. Ethnic groups and boundaries: the social organization of culture difference. Long Grove: Waveland Press.

- Berndt, Guido M., and Roland Steinacher. 2014. Arianism: Roman heresy and barbarian creed. London: Routledge.

- Bowersock, G.W., Peter Brown, and Oleg Grabar. 2012. Late Antiquity: a guide to the postClassical world. Cambridge, Mass.: Belknap Press of Harvard University Press.

- Brakke, David, Deborah Mauskopf Deliyannis, and Edward Jay Watts. 2012. Shifting cultural frontiers in late antiquity. Farnham, Surrey: Ashgate.

- Buchberger, Erica. 2017. Shifting Ethnic Identities in Spain and Gaul, 500-700: From Romans to Goths and Franks. Amsterdam: Amsterdam University Press.

- Burns, J. Patout, Robin Margaret Jensen, and Graeme Wilber Clarke. 2014. Christianity in Roman Africa: the development of its practices and beliefs. Grand Rapids, Michigan: William B. Eerdmans Publishing Company.

- Cassiodorus, and S. J. B. Barnish. 1992. The Variae of Magnus Aurelius Cassiodorus Senator, being documents of the kingdom of the Ostrogoths in Italy, chosen. Liverpool: Liverpool University Press.

- Chalon, Michel; Georges Devallet; Paul Force; Michel Griffe; Jean-Marie Lassère; and Jean-Noël Michaud. 1985. Memorabile factum. Une célébration de l'évergétisme des rois vandales dans l'Anthologie latine. Antiquités Africaines.

- Chastagnol, André, and Noël Duval. 1974. "Les survivances du culte impérial en Afrique du Nord à l'époque vandale," Bulletin De La Société Nationale Des Antiquaires De France. 1972 (1): 194-198.

- Clover, Frank M. “Felix Karthago,” Dumbarton Oaks Papers 40 (1986): 1-16.

- Collins, Roger. 2004. Visigothic Spain, 409-711. Malden, MA: Blackwell Pub.

- Conant, Jonathan. 2012. Staying Roman: conquest and identity in Africa and the Mediterranean, 439-700. Cambridge: Cambridge University Press.

- Croke, Brian. 2001. Count Marcellinus and his chronicle. Oxford: Oxford University Press.

- Curta, Florin. 2010. Neglected Barbarians. Turnhout: Brepols Publishers. 
- Deanesly, Margaret. 1991. A History of the medieval Church, 590-1500. London: Routledge.

- Decret, Francois, and Edward Smither. 2011. Early Christianity in North Africa. Cambridge: James Clarke \& Co.

- Deliyannis, Deborah Mauskopf. 2014. Ravenna in late antiquity. Cambridge: Cambridge University Press.

- Diesner, Hans-Joachim. 1967. Die Auswirkungen der Religionspolitik Thrasamunds und Hilderichs auf Ostgoten und Byzantiner. Berlin: Akademie-Verlag.

- Dignas, Beate, and Engelbert Winter. 2012. Rome and Persia in late antiquity: neighbours and rivals. Cambridge: Cambridge University Press.

- Dossey, L. 2003. “The Last Days of Vandal Africa. An Arian Commentary on Job and Its Historical Context." Journal of Theological Studies, Oxford. 54: 60-138.

- Duval, Noël. 1984. "Culte monarchique dans l'Afrique vandale : culte des rois ou culte des empereurs?” Revue D'Etudes Augustiniennes Et Patristiques. 30(3-4): 269-273.

- Elsner, Jaś, and Jesús Hernández Lobato. 2017. The poetics of late Latin literature. New York: Oxford University Press.

- Esmonde Cleary, A. S. 2016. The Roman West: AD 200-500; an archaeological study.

- Fulgentius, Claudius Gordianus, and Robert B. Eno. 1997. Fulgentius: selected works. Washington, D.C.: The Catholic University of America Press

- Fulgentius, Fabius Planciades. 2010. De aetatibus mundi et hominis. Turnhout: Brepols Publishers.

- Gaggero, G. 1996. “Alani nel Nord Africa," in L'Africa romana: atti dell' XI convegno di studio ; Cartagine, 15-18 dicembre 1994. 3. Ed. Moustapha Khanoussi. Ozieri: Il Torchietto.

- Gantner, Clemens, Richard Payne, and Walter Pohl. 2016. Visions of Community in the PostRoman World: The West, Byzantium and the Islamic World, 300-1100. London: Taylor and Francis.

- Geary, Patrick J. 2001. The Myth of Nations: the peoples of Europe from late antiquity to early Middle Ages. Princeton, N.J.: Princeton University Press.

- Geyer, Paul. 1965. Itineraria et alia geographica. Turnhout: Brepols Publishers.

- Gibbon, Edward, and Henry Hart Milman. 1843. The history of the decline and fall of the Roman empire. New York: Harper \& Bros.

- Goffart, Walter. 2010. Barbarian Tides: The Migration Age and the Later Roman Empire. Philadelphia: University of Pennsylvania Press.

- Gregory Turonensis, and Lewis Thorpe. 1974. The history of the Franks. Translated with an introduction by Lewis Thorpe. Harmondsworth, Middlesex: Penguin Books.

- Hall, Jonathan M. 2010. Ethnic Identity in Greek Antiquity. Cambridge: Cambridge University Press.

- Halsall, Guy. 2007. Barbarian migrations and the Roman West, 376-568. Cambridge: Cambridge University Press.

- Heather, Peter. 2007. The fall of the Roman Empire: a new history of Rome and the Barbarians. Oxford: Oxford University Press.

- Hornblower, Simon; Antony Spawforth; and Esther Eidinow. 2012. The Oxford classical dictionary. Oxford: Oxford University Press.

- Hydatius, Chronicon. Accessed at http://www.thelatinlibrary.com/hydatiuschronicon.html.

- James, Edward. 1990. The origins of France: from Clovis to the Capetians, 500-1000. 
Basingstoke: Macmillan.

- James, Edward. 2015. Europe's barbarians AD 200-600. London: Routledge Taylor \& Francis Group.

- Johnson, Scott Fitzgerald. 2016. The Oxford handbook of late antiquity. New York: Oxford University Press.

- Johnston, Patricia A. 2016. Animals in Greek and Roman religion and myth: proceedings of the Symposium Grumentinum, Grumento Nova (Potenza), 5-7 June 2013. Newcastle-uponTyne: Cambridge Scholars Publ.

- Kahlos, Maijastina. 2009. Forbearance and compulsion the rhetoric of religious tolerance and intolerance in late antiquity. London: Duckworth.

- Kahlos, Maijastina. 2016. Debate and dialogue: Christian and pagan cultures c. 360-430. London: Routledge.

- Lee, A.D. 2013. From Rome to Byzantium, AD 363-565: the transformation of ancient Rome. Edinburgh: Edinburgh University Press.

- Leone, Anna. 2013. The end of the pagan city: religion, economy, and urbanism in late antique North Africa.

- Loomis, Louise Ropes. 1965. The book of the Popes: Liber pontificalis. New York: Octagon Books.

- Maas, Michael. 2015. The Cambridge companion to the age of Attila. New York, NY [u.a.]: Cambridge University Press.

- Menander Protector, Fragments, trans. R.C. Blockley. Accessed at https://www.sasanika. org/wp-content/uploads/Menander6-1.pdf.

- Merrills, A. H. 2004. Vandals, Romans and Berbers: new perspectives on late antique North Africa.

- Merrills, Andy H., and Richard Miles. 2010. The Vandals.

- Miles, Richard. 2005. "The Anthologia Latina and the creation of a secular space in Vandal Carthage." Antiquité Tardive. 13: 305-320.

- Mitchell, Stephen, and Geoffrey Greatrex. 2001. Ethnicity and culture in late antiquity. London: Duckworth.

- Moderan, Yves. 2003. Les Maures et l'Afrique romaine (IVe-VIIe siecle). Rome: Publications de l'Ecole francaise de Rome.

- Moorhead, John. 1997. Theoderic in Italy. Oxford: Clarendon Press.

- Nofziger, Christopher J. 2012. "Reign of heretics: Arianism and political power in the Vandal and Ostrogothic kingdoms." M.A. Thesis, Western Washington University.

- North, Richard. 2015. "You Sexy Beast: The Pig in a Villa in Vandalic North Africa, and Boar-Cults in Old Germanic Heathendom," in Representing Beasts in Early Medieval England and Scandinavia, edited by Bintley, Michael D. J., and Thomas J. T. Williams, 151175. Woodbridge, Suffolk: The Boydell Press.

- O'Donnell, James Joseph. 2009. The ruin of the Roman Empire. New York: Harper Perennial.

- Onesti, Nicoletta Francovich. 2005. "Latin-Germanic hybrid names from Vandal Africa and related problems," in Proceedings of the 21st International congress of Onomastic Sciences, Uppsala 19-24 August 2002. 2 2. Ed. Eva Brylla and Mats Wahlberg. Uppsala: Språk-och Folkminnesinst.

- Parthemius, Rescriptem ad Sigisteum. Accessed at http://latin.packhum.org/loc/2456/1/0\#0. 
- Patzold, Steffen; Anja Rathmann-Lutz; and Volker Scior. 2012. Geschichtsvorstellungen: Bilder, Texte und Begriffe aus dem Mittelalter. Festschrift für Hans-Werner Goetz zum 65. Geburtstag. Wien: Böhlau.

- Pohl, Walter, and Gerda Heydemann. 2013. Post-Roman transitions: Christian and Barbarian identities in the early medieval West. Turnhout: Brepols Publishers.

- Pohl, Walter, and Gerda Heydemann. 2013. Strategies of identification: Ethnicity and Religion in Early Medieval Europe. Turnhout: Brepols Publishers.

- Pohl, Walter, and Helmut Reimitz. 1998. Strategies of distinction: the construction of ethnic communities, 300-800. Leiden: Brill.

- Procopius Caesariensis, and Henry Bronson Dewing. 1979. Procopius: in seven volumes. London: Heinemann.

- Rupke, Jorg, and Eric Rebillard. 2015. Group identity and religious individuality in late antiquity. Washington D.C.: The Catholic University of America Press.

- Shanzer, Danuta, and Ralph Whitney Mathisen. 2011. Romans, barbarians, and the transformation of the Roman world: cultural interaction and the creation of identity in late antiquity. Farnham: Ashgate.

- Shaw, Brent D. 2011. Sacred Violence: African Christians and Sectarian Hatred in the Age of Augustine. Cambridge: Cambridge University Press.

- Southern, Pat, and Karen R. Dixon. 1996. The late Roman army. London: B.T. Batsford.

- Surdu, Mihai. 2017. Those Who Count: Expert Practices of Roma Classification. Budapest: Central European University Press.

- Theodosius, Codex Theodosianus. Accessed at www.thelatinlibrary.com/theodosius.html.

- Tilley, Maureen A. 1996. Donatist martyr stories: the Church in conflict in Roman North Africa. Liverpool: Liverpool University Press.

- Traina, Giusto, and Averil Cameron. 2011. 428 AD: an Ordinary Year at the End of the Roman Empire. Princeton: Princeton University Press.

- Victor Vitensis, and John Moorhead. 2006. History of the Vandal persecution. Liverpool: Liverpool University Press.

- Victor Vitensis, and Karl Halm. 1993. Victoris Vitensis Historia persecutionis africanae provinciae. München: Monumenta Germaniae Historiae.

- Von Rummel, Philipp. 2003. "Habitus Vandalorum? Zur Frage nach einer gruppenspezifischen Kleidung der Vandalen in Nordafrika." Antiquité Tardive. 10: 131-141.

- Ward-Perkins, Bryan. 2005. The fall of Rome and the end of civilization. Oxford: Oxford University Press.

- Whelan, Robin. 2014. "African Controversy: The Inheritance of the Donatist Schism in Vandal Africa." Journal of Ecclesastical History. 65 (3): 504-521.

- Whelan, Robin. 2018. Being Christian in Vandal Africa: the politics of orthodoxy in the Post-Imperial West. Oakland, California: University of California Press.

- Wijnendaele, Jeroen W.P. 2012. Review of The Vandals, by A. Merrills and R. Miles. Melbourne Historical Journal. 40: 202-205.

- Wilhite, David E. 2017. Ancient African Christianity. An introduction to a unique context and tradition. Basingstoke: Taylor \& Francis Ltd.

- Willems, W. J. H., and Harry van Enckevort. 2009. Vlpia Noviomagvs, Roman Nijmegen. Portsmouth, R.I.: JRA.

- Wolfram, Herwig. 2005. The Roman Empire and its Germanic peoples. Berkeley, California: 
University of California Press. 